\title{
CAPITAL, PRODUTIVIDADE E CRESCIMENTO DA AGRICULTURA: O BRASIL DE 1970 A 1995
}

\section{ALEXANDRE LAHÓZ MENDONÇA DE BARROS}

Engenheiro Agrônomo

Orientador: Prof. Dr. GERALDO SANT'ANA DE CAMARGO BARROS

Tese apresentada à Escola Superior de Agricultura "Luiz de Queiroz", Universidade de São Paulo, para obtenção do título de Doutor em Ciências. Área de Concentração: Economia Aplicada.

P I R A C I C A B A

Estado de São Paulo - Brasil

Janeiro - 1999 
Dados Internacionais de Catalogação na Publicação (CIP) DIVISÃo DE BIBLIOTECA E DOCUMENTAÇÃO - Campus "Luiz de Queiroz"/USP

Barros, Alexandre Lahóz Mendonça de

Capital, produtividade e crescimento da agricultura: o Brasil de 1970 a 1995 / Alexandre Lahóz Mendonça de Barros. - - Piracicaba, 1999.

$149 \mathrm{p}$.

Tese (doutorado) - - Escola Superior de Agricultura Luiz de Queiroz, 1999. Bibliografia.

1. Capital 2. Crescimento econômico 3. Desenvolvimento agrícola 4. Economia agricola 5. Investimento agricola 6. Produtividade agricola I. Título

CDD 338.1 


\section{CAPITAL, PRODUTIVIDADE E CRESCIMENTO DA AGRICULTURA: O BRASIL DE 1970 A 1995}

ALEXANDRE LAHÓZ MENDONÇA DE BARROS

Prof. Dr. GERALDO SANT'ANA DE CAMARGO BARROS Orientador 
Ao meu avô Salvador Lahóz e à Mariana 


\section{AGRADECIMENTOS}

Gostaria de agradecer ao meu orientador durante todo o programa de doutoramento, professor Geraldo Sant'ana de Camargo Barros, por ter-me mantido na direção de meus verdadeiros interesses.

Aos professores Joaquim Bento de Souza Ferreira Filho e Míriam Rumenos Piedade Bacchi, meus especiais agradecimentos pelas valiosas contribuições feitas em versões anteriores do trabalho. A atenção com que atenderam minhas dúvidas e o cuidado analítico demonstrado, serviram em muito para melhorar os resultados alcançados.

Ao longo do período de estudos no Departamento de Economia e Sociologia Rural tive a sorte de conviver com dois professores que muito me auxiliaram em minha formação. Ao amigo e professor Oriowaldo Queda gostaria de agradecer as inúmeras conversas que mantivemos nesses anos. Seu espírito crítico, seu incorfomismo com o lugar comum, serviram para despertar meu interesse por diversas questões econômicas e sociais de grande importância. Ao professor Rodolfo Hoffmann agradeço a paciência com tantas perguntas que lhe fiz. Admiro sua seriedade e competência profissional, seu desprendimento no aux̧ílio aos outros.

Aos demais professores do Departamento de Economia, Administração e Sociologia da ESALQ meu melhor reconhecimento pelo apoio recebido, por tudo que me ensinaram. A todos funcionários não docentes do Departamento também estendo minha gratidão.

A Júnia e Pedro Conceição com quem conversei longamente sobre as questões referentes ao crescimento da agricultura brasileira. Junto com o Dr. José Garcia Gasques, foram fundamentais no auxílio a esta pesquisa. 
Aos ilustres economistas Mônica Baer, Celso Toledo, Genilson Santana e Cristiano Souza com os quais espero trabalhar por muito tempo, o melhor agradecimento de um amigo.

Aos meus pais José Roberto e Ruth que me ensinaram a enxergar a beleza do conhecimento. Aos meus irmãos André e Carolina, companheiros de todos os caminhos e momentos, que muito me apoiaram.

A Mariana a quem amo tanto.

A Paulo Fernando Cidade de Araújo que de meu professor tornou-se grande amigo. A ele serei eternamente grato por ter-me despertado o interesse pela teoria do desenvolvimento econômico e pela preocupação com o longo prazo. Numa ciência cada dia mais fria, sua paixão pelo futuro serviu de estímulo para seguir meu trabalho adiante. Espero poder transmitir os conhecimentos que venha acumular com a mesma emoção que a mim foram por ele passados.

Gostaria, por fim, de agradecer ao professor José Roberto Mendonça de Barros pelo profundo respeito à minha integridade intelectual. 


\section{SUMÁRIO}

Página

LISTA DE FIGURAS ............................................................................... ix

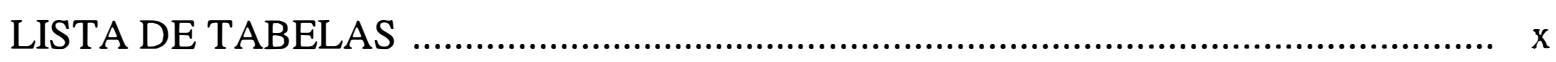

LISTA DE QUADROS ............................................................................... xii

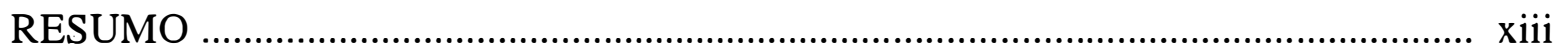

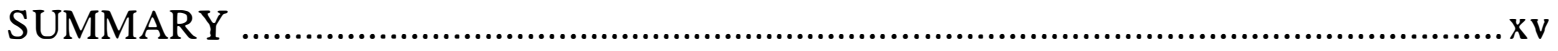

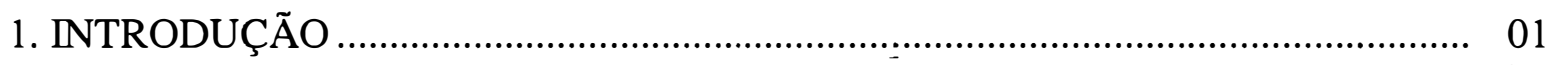

2. O PROBLEMA E SEU CONTEXTO ............................................................. 03

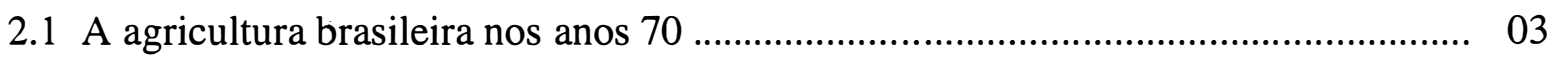

2.2. A agricultura brasileira nos anos 80 e 90 .................................................... 09

2.3 Agricultura e ciclos econômicos ................................................................... 16

$2.4 \mathrm{O}$ ajustamento estrutural da agricultura brasileira nos anos 80 ........................... 21

2.5 Os determinantes do crescimento .................................................................. 26

3. O MODELO: TOMADA DE DECISÃO DA FIRMA …....................................... 37

4. INVESTIMENTO ACUMULADO: O ESTOQUE DE TRATORES ..................... 46

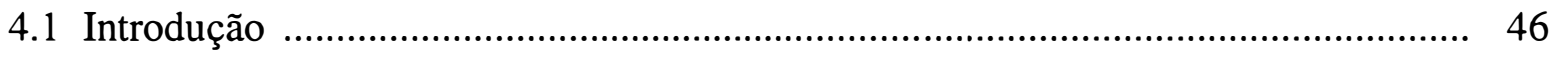

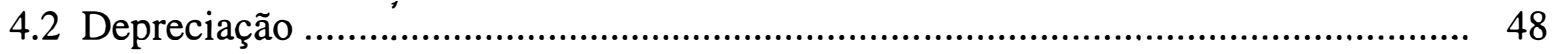

4.3. Medida da depreciação e do estoque de tratores no Brasil .................................. 54

4.3.1 A base de dados ................................................................................... 54

4.3.2 A análise dos dados de depreciação .............................................................. 56

4.4 A construção do estoque de tratores ................................................................ 61

5. PRODUTIVIDADE TOTAL DOS FATORES NA AGRICULTURA

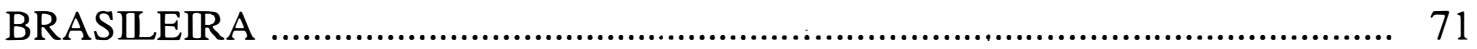

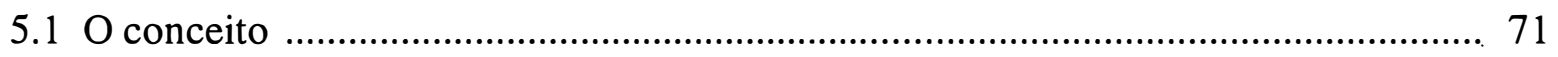

5.2 Os métodos de cálculo da produtividade total dos fatores ................................. 75 


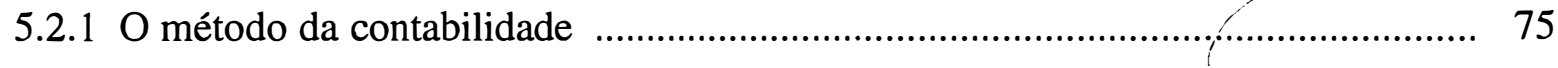

5.2.2 O método da função de produção ........................................................................ 79

5.2.3 O métódo não-paramétrico de medida da produtividade .................................... 84

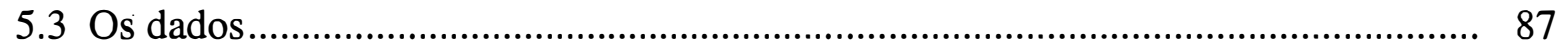

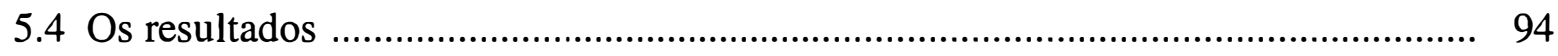

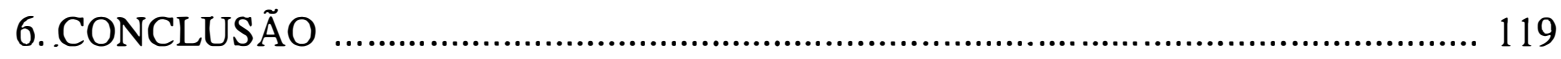

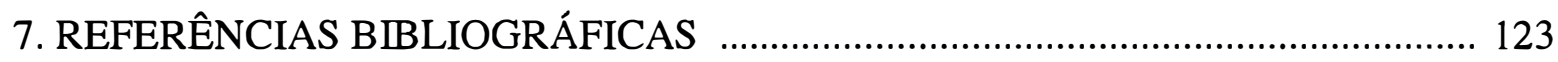

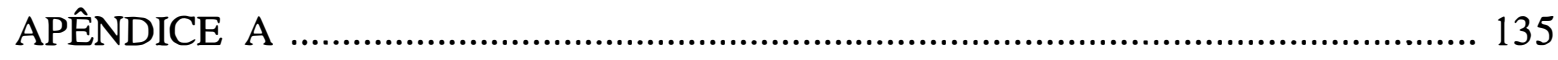

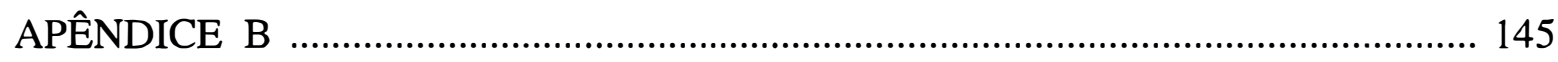




\section{LISTA DE FIGURAS}

Página

1. Índice de evolução da área cultivada com lavouras anuais e permanentes,

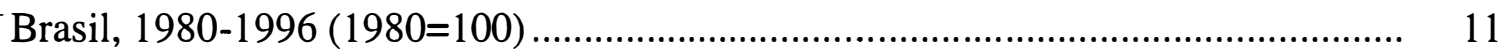

2. Relação entre crédito formal e PIB agropecuário, Brasil, 1970-1996(\%) ............... 15

3. Índice de preço médio dos tratores Massey Fergusson 275 e 290 com zero a vinte e um anos de uso (\% do trator novo)

4. Taxa média de variação anual dos preços dos tratores Massey Fergusson 275 e 290 com vinte e um anos de uso

5. Estoque de tratores medido em valor, número de tratores, número de cavalo vapor entre 1970 e $1997(1970=100)$

6. Número de hectares cultivados por trator entre 1973-1995

7. Comparação dos estoques de tratores calculados com taxa de depreciação linear (10\%) e estoque baseado nos Censos Agropecuários entre 19701997 (em unidades)

8. Evolução da produtividade total dos tratores entre os anos de 1975-1995 


\section{LISTA DE TABELAS}

Página

1. Taxas de crescimento médio anual das quantidades produzidas e dos rendimentos físicos de lavouras selecionadas, 1971-1980 (\%)

2. Decomposição da taxa anual de crescimento da produção agrícola brasileira, 1970-1980 (\%)

3. Relação entre o valor do produto agrícola exportado e valor do produto agrícola total, Brasil, 1970-1996

4. Índice de valor da relação preço do produto/custo unitário de produção e relação preços recebidos/preços pagos por insumos de fora da propriedade rural $(1980=100)$

5. Vendas anuais e médias quinquenais de vendas de tratores de rodas ao mercado interno, Brasil, 1970-1996

6. Coeficiente de depreciação estimada para os preços de tratores MF 275, MF 290 e para a combinação das duas séries

7. Número de tratores de roda presentes nos Censos Agropecuários, número de tratores estimadó e diferença percentual dos estoques

8. Estoque de tratores medido em valor, número de tratores e número de cavalo vapor entre 1970 e 1997 (valores em $R \$$ de dezembro de 1995)

9. Número de hectares por trator, pessoas por trator, cavalos vapor por pessoa e valor do capital por pessoa na agricultura brasileira, 1973 a 1995

10. Pessoal ocupado e equivalentes-homem nos Censos Agropecuários de 1970, 1975, 1980, 1985 e 1995 (em número total de pessoas)

11. Produtividades parciais do capital e produtividade total dos fatores com diferentes formas de mensuração do estoque 
12. Valor do produto físico médio, do produto físico marginal e taxa de retorno do capital investido para tratores de 75 e de $140 \mathrm{cv}$ (valores em $\mathrm{R} \$$ de dezembro de 1995)

13. Evolução da produtividade total dos fatores medida pelo método do Índice de Tornquist

14. Evolução da produtividade total dos fatores medida pelo método da Contabilidade 


\section{LISTA DE QUADRO}

Página

1. Coeficientes de correlação simples entre as variáveis explicativas ........................ 95

2. Funções de produção estimadas ........................................................................ 97

3. Teste de raiz unitária para séries de valor da produção, estoque de capital, mão-de-obra e área ............................................................................... 100

4. Teste de cointegração para séries nas diferentes funções de produção

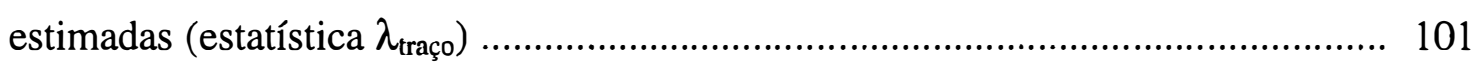

5. Esquema da contabilidade do crescimento da agricultura, 1975-1995 .................... 103

6. Ganhos anuais da produtividade total dos fatores na agricultura de

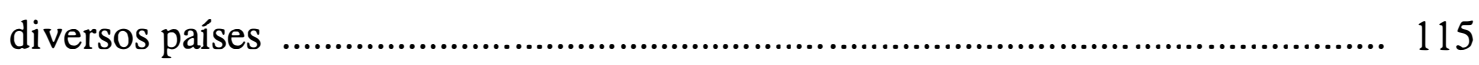

7. Ganhos anuais da produtividade total dos fatores na agricultura brasileira .............. 116 


\title{
CAPITAL, PRODUTIVIDADE E CRESCIMENTO DA AGRICULTURA: O BRASIL DE 1970 A 1995
}

\author{
Autor: Alexandre Lahóz Mendonça de Barros \\ Orientador: Prof. Dr. Geraldo Sant'Ana de Camargo Barros
}

\section{RESUMO}

O presente trabalho se preocupa com o processo de acumulação de capital, de evolução da produtividade total dos fatores e de crescimento da agricultura brasileira entre 1970 e 1995.

O éstudo parte da construção do estoque de tratores de rodas sob três formas alternativas, quais sejam: i) em número total de tratores; ii) em potência (cavalos-vapor); e iii) em valor total. O estoque de tratores foi usado como aproximação do estoque total de capital na agricultura. A série de valor do estoque foi constituída a partir dos preços de tratores de segunda-mão. Com base nesses preços determinou-se que a taxa de depreciação foi de $6 \%$ ao ano no período analisado.

Uma vez estabelecido o estoque de capital calcularam-se os ganhos de produtividade total dos fatores (PTF). Foram utilizadas três formas alternativas de medida da PTF: i) método da função de produção; ii) método da contabilidade (seguindo Solow, 1957); iii) método não-paramétrico (índice de Tornquist-Theil). No primeiro caso estimouse uma função de produção do tipo Cobb-Douglas que serviu tanto para testar a hipótese de retornos constantes à escala, quanto para determinar a participação dos fatores no produto. 
De posse dos parâmetros da função e produção, avaliou-se os impactos das diferentes formas de medida do capital na PTF.

Os resultados indicam que houve, de fato, um forte processo de acumulação de capital entre 1970 e 1995. O estoque de tratores aumentou 4 vezes em valor, 5 vezes em número e 6 vezes em potência no período de 1970 a 1995. Entretanto, a partir de 1990 o valor da frota começa a declinar, sinalizando um processo de envelhecimento do estoque de máquinas agrícolas. Entre 1973 e 1995 houve redução do número de hectares por trator (passando de 165 ha/trator para 64 ha/trator), uma diminuição de 4 vezes no número de pessoas ocupadas por trator ( de 64 pessoas/trator em 1973 para 18 em 1995) e um aumento na potência média da frota (de $70 \mathrm{cv}$ por trator no início do período para $81 \mathrm{cv}$ no final). Esses números expressam a verdadeira dimensão do processo de capitalização da agricultura brasileira.

As estimativas desta pesquisa dão conta de um aumento do produto de $3,26 \%$ ao ano entre 1975 e 1995. A produtividade da terra elevou-se em $2,47 \%$ ao ano e a do trabalho em 3,26\% ao ano. Constatou-se, ainda, que a produtividade total dos fatores cresceu à taxa de $1,6 \%$ ao no quando se usa o estoque de capital medido em valor e $1 \%$ ao ano quando o estoque é medido em potência. Por fim, estimou-se que 1/3 do crescimento do produto foi explicado pela elevação da produtividade total dos fatores, cabendo ao aumento dos insumos (capital, terra e mão-de-obra) os outros 2/3. Esses resultados encontram-se em concordância com aqueles obtidos em diversos estudos realizados em diferentes países desenvolvidos e subdesenvolvidos. 


\title{
CAPITAL , PRODUCTIVITY AND AGRICULTURAL GROWTH: BRAZIL FROM 1970 TO 1995
}

\author{
Autor: Alexandre Lahóz Mendonça de Barros \\ Orientador: Prof. Dr. Geraldo Sant'Ana de Camargo Barros
}

\section{SUMMARY}

This work is concerned with the process of capital formation, evolution of total factor productivity (TFP) and growth of the Brazilian agricultural sector between 1970 and 1995.

The study starts building the stock of wheel tractors measured in 3 alternative ways: i) number of tractors; ii) total horse power; and iii) total value. The stock of tractors works as a proxi of the total capital stock in agriculture. The value series was constructed based on the prices of second-hand tractors. It was determined that the rate of depreciation is $6 \%$ per year.

Once the stock of capital was estimated, followed by the growth of the parcial and total factor productivities. Three alternative methods were used to account for TFP: i) the production function method; ii) the growth accounting method (after Solow, 1957); iii) the index number method (Tornquist-Theil index). In the first one, it was estimated a CobbDouglas production function that was used both to test the hipothesis of constant returns to scale and to estimate the factors shares in total product. With the parameters of the production function at hand, it was possible to evaluate the impacts of the alternative measures of capital over the values of TFP. 
The results indicated that the process of capital accumulation was substantial between 1970 and 1995. The stock of capital raised 4 times in value, 5 times in number and 6 times in total horse power in that period. However, after 1990 the value of the stock started to decline, indicating that the tractor fleet is aging. Between 1973 and 1995 it was observed a reduction in the number of cultivated land per tractor (from 164 ha/tractor to 64 ha/tractor), a 4 times decrease in the number of workers per tractor (from 64 persons/tractor in 1973 to 18 persons/tractor in 1995) and an increase in the average horse power (from 70 $\mathrm{hp} /$ tractor to $81 \mathrm{hp} /$ tractor). These figures give dimension to the process of capital formation in the Brazilian agriculture during those 25 years.

The results of this study showed also that the growth rate of agricultural production was equivalent to $3.26 \%$ a year. Land productivity increased by $2.47 \%$ per year and labor productivity raised $3.26 \%$ a year. It was found also that total factor productivity growth between 1970 and 1995 was $1.6 \%$ a year when the value of the stock of capital was used and $1 \%$ when the horse power stock was considered. Finally, it was estimated that $2 / 3$ of the growth rate of agricultural production was explained by the more intensive use of farm inputs (capital, land and labor); 1/3 of the output growth rate was determined by total factor productivity. These findings are very consistent with those obtained in several studies done in other countries facing different stages of development. 


\section{1 - INTRODUÇÃO}

O presente trabalho pretende investigar o processo de formação de capital e de evolução da produtividade na agricultura brasileira, sabidamente duas questões centrais ao crescimento econômico. O estudo é essencialmente de economia aplicada. Quer-se avaliar, empiricamente, o que vem acontecendo com os investimentos no setor nos últimos 25 anos. Teria ocorrido um processo de depreciação do estoque de capital em decorrência do desajuste macroeconômico por que passou a economia brasileira nos últimos anos? Qual o impacto da redução da interferência do Estado sobre os investimentos em máquinas agrícolas?

A avaliação partirá da construção de formas alternativas de mensuração do estoque de tratores agrícolas no Brasil. O comportamento dos investimentos em tratores servirá como proxy das tendências da formação de capital no setor. Sabe-se, de antemão, que esse procedimento é uma aproximação imprecisa do comportamento do estoque de capital agregado. Ocorre, contudo, que o mercado de tratores é, dentre os componentes do estoque de capital físico, aquele que permite uma inferência empírica mais profunda, em razão da confiabilidade e periodicidade dos dados disponíveis. Julgamos ser esse o melhor procedimento possível.

Uma vez construídas as séries de capital, a pesquisa estima as alterações da produtividade total dos fatores no período de 1975 a 1995. Faz-se uso de medidas alternativas de cômputo da produtividade com o intuito de testar a solidez dos 
resultados. Adicionalmente, pretende-se avaliar quais os impactos causados na produtividade total dos fatores quando diferentes formas de mensuração do estoque são utilizadas.

O trabalho divide-se em cinco capítulos. No primeiro apresenta-se uma revisão acerca da evolução da agricultura brasileira desde os anos 70 até os 90 . O objetivo do capítulo é recuperar diferentes avaliações a respeito do padrão crescimento do setor nos últimos 25 anos. O segundo capítulo desenvolve um modelo teórico, utilizado por Barros (1980), sobre a tomada de decisão da firma quanto aos investimento em máquinas e equipamentos. Em especial, o modelo sintetiza quais as variáveis que afetam os investimentos e como os agentes reagem às alterações dos ciclos econômicos. No terceiro capítulo constrói-se o estoque de tratores no Brasil. Fazendo uso das séries anuais de vendas de tratores, dos dados dos Censos Agropecuários e de preços de tratores de segunda mão, estima-se o estoque de tratores de rodas em três formas alternativas, quais sejam: em valor, em unidades de tratores e em potência. $\mathrm{O}$ quarto capítulo apresenta as formas alternativas de medida da produtividade total dos fatores utilizadas nos diferentes estudos empíricos. A partir dos resultados do capítulo 3, avaliam-se quais as alterações na evolução da produtividade total dos fatores em decorrência do uso de formas alternativas de medida do capital. O trabalho é encerrado com as conclusões da pesquisa. 


\section{2 - O PROBLEMA E SEU CONTEXTO}

\section{1 - A agricultura brasileira nos anos 70}

No final dos anos 70 a maior parte dos estudiosos em economia agrícola antevia uma crise na produção da agricultura brasileira para os anos seguintes. Até então o setor tinha conseguido expandir a produção a taxas anuais que oscilaram entre 4 e $6 \%^{1}$, tidas como suficientes para atender os principais papéis exigidos ao setor, quais sejam: 1) contribuir para o crescimento do produto; 2) gerar divisas, aumentando o esforço exportador; e 3) abastecer o mercado interno sem gerar pressões sobre os índices de custo de vida (Mendonça de Barros e Graham, 1978).

A partir dos anos 70, contudo, passou-se a observar uma diminuição nas taxas de crescimento de parcela significativa da produção agrícola, gerando pressão inflacionária que se tornava especialmente relevante dada a alta concentração da renda no país.

Constatava-se, então, uma crescente segmentação entre dois grupos de produtos agrícolas que passaram a ser classificados como domésticos e exportáveis ${ }^{2}$. O elemento que distinguia um grupo do outro era a formação de preços: no primeiro eram formados pela oferta e demanda internas, enquanto no segundo grupo eram dados pelo mercado internacional (Mendonça de Barros e Graham, 1978). O setor de exportáveis vinha

\footnotetext{
' Para uma avaliação do desempenho da agricultura brasileira até 1970, ver Mendonça de Barros, Pastore e Rizzieri (1983); para o período 1970-1980, Dias e Mendonça de Barros (1983) e Mendonça de Barros, Graham e Gautier (1987).

${ }^{2}$ Faziam parte dos produtos domésticos, segundo Barros e Graham (1978), trigo, arroz, feijão, mandioca, milho, cebola, tomate. Os exportáveis eram cacau, algodão, cana-de-açúcar, café, soja, fumo e laranja.
} 
mostrando uma dinâmica muito mais vigorosa, crescendo a taxas de $5 \%$ a.a.. Os produtos domésticos, por seu turno, chegaram a apresentar decréscimo de $4 \%$ no produto total no período de 1970-1975, segundo os autores acima citados.

A tabela 1, sintetizada de Goldin e Rezende (1993), mostra quão assimétrico foi o padrão de crescimento da produção e da produtividade entre os dois grupos. Note-se que entre 1971 e 1980 as quantidades produzidas de soja e de laranja chegaram a aumentar às taxas de 18,6\% e 11,8\% a.a., respectivamente. Vale observar que os ganhos de produtividade foram bem mais modestos e, em alguns casos, negativos. Nos produtos de consumo interno percebe-se que a elevação da quantidade produzida foi bem menor, com diminuição na quantidade ofertada de feijão e mandioca. Em diversos casos houve redução na produtividade.

Tabela 1 - Taxas de Crescimento Médio Anual das Quantidades Produzidas e dos Rendimentos Físicos de Lavouras Selecionadas , 1971-1980 (\%)

\begin{tabular}{lcc}
\hline Lavoura & Quantidade Produzida & Rendimento Físico \\
\hline Exportáveis & 18,6 & 1,1 \\
Soja & 11,8 & 3,0 \\
Laranja & 7,0 & 2,4 \\
Cana-de-açúcar & 6,8 & 2,7 \\
Fumo & 5,6 & $-2,6$ \\
Cacau & $-3,1$ & 5,2 \\
Café & $-4,8$ & $-3,0$ \\
Algodão & & \\
Domésticos & 6,9 & 1,1 \\
Trigo & 2,6 & $-0,3$ \\
Milho & 2,7 & $-4,6$ \\
Arroz & $-2,2$ & 1,3 \\
Mandioca & $-2,7$ & $-2,4$ \\
Feijão & & \\
\hline
\end{tabular}

Fonte: Goldin e Rezende (1993)

Esse baixo desempenho dos produtos domésticos comprometia o bem-estar da maior parte da população, uma vez que esses produtos eram muito relevantes na composição da cesta básica de consumo (veja Homem de Melo,1988). 
A perda de dinamismo da produção dos principais alimentos componentes da cesta básica acarretou uma elevação nos preços dos mesmos ao longo da maior parte dos anos 70: Mendonça de Barros (1979) indíca que entre 1970 e 1977 houve um aumento real de $52 \%$ no preço dos alimentos. Como decorrência deste movimento o autor sinaliza que o papel principal da agricultura passa a ser o da estabilidade interna:

“...Entretanto também faz parte da experiência brasileira a ocorrência de sérios problemas de equilíbrio interno (inflação) e equilíbrio externo (balanço de pagamentos), e é nesses pontos que vai se reposicionar a agricultura. Em outras palavras, a agricultura deixa de ser um problema de crescimento para ser de estabilidade. Dada a importância do setor primário na formação de um preço básico do sistema, o salário (via custo da alimentação e vestuário); e na geração de divisas, pode-se observar com muita nitidez que para aí se desloca o interesse da política agregada, definindo um padrão de desempenho (esperado) do setor primário." (página 09)

Como apontam Mendonça de Barros e Graham (1978), argumentava-se que o baixo desempenho do setor doméstico era decorrente, em alguma medida, da própria dinâmica do setor de exportáveis. A produção para exportação reduziria a produção doméstica de alimentos ao gerar um efeito de substituição na composição do produto, acirrando a disputa por fatores de produção, principalmente a terra ${ }^{3}$. Além disso o aumento na produção de exportáveis acabava por reduzir o emprego dos moradores residentes ao serem adotadas tecnologias que privilegiavam o uso intenso de terras e maquinaria. Como o excedente de produção dessa população representava parte considerável da oferta interna de alimentos, a diminuição da mesma acarretou um decréscimo na produção dos domésticos, (Rezende, 1986).

\footnotetext{
${ }^{3}$ Vale ressaltar que essa afirmação pressupõe oferta inelástica de um ou mais fatores de produção, o que passa a exigir certa cautela quanto a força do argumento. Certamente a oferta de terra é inelástica no curto e, principalmente, longo prazo; no médio prazo isso não se mostrou verdadeiro no Brasil dos anos 80 quando ocorreu a ocupação do cerrado, na região Centro-Oeste.
} 
Numa sequiência de artigos Homem de Melo (1978, 1979, 1983) conclui que o setor doméstico apreśentou maior variabilidade de preços, rendimentos e renda do que o setor de exportáveis ao longo dos anos 70. Essa maior variância traduzia-se em maior incerteza e portanto, risco, na produção daquele sub-setor da agricultura. Ora, na medida em que o risco aumentava, os agricultores passariam a deslocar a produção para o sub-setor dos exportáveis, uma vez que este apresentava maior segurança às inversões. Segundo o mesmo autor, a maior incerteza associada aos produtos domésticos devia-se, em boa medida, às políticas discricionárias adotadas pelo governo com relação ao setor. As constantes mudanças na conduta da política agrícola tornava nebuloso o processo de formação de preços, conferindo imprevisibilidade quanto ao preço futuro e, dessa maneira, desestimulando o plantio daqueles produtos. Os produtos exportáveis, por estarem sujeitos aos preços no mercado internacional, não sofriam dos mesmos problemas.

Manoel e Mendonça de Barros (1987) corroboram com os efeitos criados pelos movimentos aleatórios na condução da política agrícola:

" Com efeito, na medida em que a instrumentação da política econômica foi regida por uma contraposição entre a ortodoxia e a heterodoxia, acabou gerando um componente de instabilidade muito grande no que diz respeito a comercialização agrícola (tanto interna quanto externa), investimentos rurais e produção industrial de insumos modernos para o setor." (página 105)

Esta maior instabilidade comprometeria os níveis de investimento no setor:

“...Como primeiro impacto pode-se arrolar as alterações nas expectativas no sentido que estas desestabilizaram o horizonte de cálculo na agricultura. Obviamente que estas ocorrências terminaram por depreciar de forma significativa os investimentos produtivos no setor." (página 110) 
Outro aspecto levantado para explicar o melhor desempenho relativo do setor exportador dizia respeito à inovação tecnológica (Mendonça de Barros 1979, Homem de Melo, 1988). O argumento central era que o setor exportador rapidamente passou a adotar em maior volume os insumos modernos, apropriando-se dos ganhos em escala que essa tecnologia proporcionava. A concentração -da produção nos eixos de exportação favoreceria a pesquisa (principalmente adaptação de variedades), bem como a disseminação do conhecimento pelos agricultores que se encontravam nesses pólos de produção.

A despeito do desempenho relativo superior dos exportáveis, uma característica básica marcava o padrão de crescimento da produção agrícola agregada: o baixo crescimento da produtividade da terra e, em alguma medida, do trabalho, principalmente na primeira metade da década.

Observava-se que a agricultura brasileira vinha crescendo basicamente em decorrência da expansão da área produtiva. Apenas o Estado de São Paulo apresentava ganhos mais expressivos de produtividade da terra. A tabela 2, reproduzida de Dias e Mendonça de Barros (1983), decompõe a taxa anual de crescimento da produção agrícola no Brasil no período 1970-1980. Pode-se observar que a taxa de aumento na produção por área é bem inferior àquela da produção total, indicando que a maior parte da expansão do produto se deveu ao aumento da área colhida. Dias (1989) calcula que $80 \%$ do cresciḿento da produção no período foi decorrente da elevação da área cultivada. Outro aspecto relevante que se depreende da referida tabela é o aumento na relação área-homem, associada à forte redução nas taxas de crescimento de absorção da mão-de-obra empregada na agricultura ${ }^{4}$. Esse comportamento indicava que o processo de mecanização da agricultura brasileira passava a ser bastante significativo. Nos capítulos subsequientes pretende-se discutir em maior profundidade esse processo.

\footnotetext{
${ }^{4}$ Para uma análise do problema do emprego no setor agrícola em contexto de substituição de importações ver' Pastore (1979).
} 
Tabela 2 - Decomposição da Taxa Anual de Crescimento da Produção Agrícola Brasileira, 1970-1980 (\%)

\begin{tabular}{lcc}
\hline Componentes & $\mathbf{1 9 7 0 ~ a ~ 1 9 7 5}$ & $\mathbf{1 9 7 5}$ a 1980 \\
\hline$\Delta$ produção/ área & 1,53 & 1,78 \\
$\Delta$ relação área/ homem & 0,27 & 3,50 \\
$\Delta$ mão-de-obra ocupada & 2,96 & 0,74 \\
$\Delta$ produção & 4,76 & 6,01 \\
\hline Fonte: Dias e Barros (1983) & &
\end{tabular}
Fonte: Dias e Barros (1983)

O problema da produção de alimentos ganhava especial destaque quando se considerava que os pequenos incrementos na produtividade acima apresentados encontravam-se associados a um período de forte dispêndio no setor. agrícola por parte do governo central. A política de crédito rural ganhou força ao longo dos anos 70 , atingindo seu auge entre 1974 e 1976, quando os volumes emprestados equivaliam ao próprio produto agrícola (Araújo e Meyer, 1979) ${ }^{5}$. Afora o valor total emprestado, chamavam atenção os subsídios implícitos nesses empréstimos. Goldin e Rezende (1993) calculam que entre 1970 e 1986 as taxas de juros nos empréstimos de crédito rural mantiveram-se sistematicamente negativas. Em 1976 o juro real foi de $-21,9 \%$, atingindo o pico de $-37,7 \%$ em 1980 .

Um dos objetivos da política de crédito rural no Brasil, segundo Araújo e Meyer (1979), era o de fomentar a modernização da agricultura brasileira através da aquisição de insumos modernos. Os volumes de insumos, de fato, apresentaram significativo aumento: enquanto em 1970 foram adquiridas 14.000 tratores de roda, esse número sobe para 63.000 unidades em 1976 (Mendonça de Barros e Manoel, 1992); entre 1975 e 1980 o consumo de fertilizantes mais do que dobra (112\%) e o de defensivos aumenta 43\% (Goldin e Rezende 1993).

\footnotetext{
${ }^{5}$ Os dados referentes ao crédito rural serão apresentados mais adiante.
} 
A despeito desse forte crescimento nas vendas de insumos modernos não era possível perceber, até então, ganhos expressivos de eficiência na produção. Quando se considerava a forte dependência da venda de fertilizantes, máquinas e defensivos ao volume de crédito rural concedido e, além disso, percebia-se o caráter não sustentável dos subsídios associados a essa política dado seu custo fiscal, antevia-se, na entrada dos anos 80 , que o problema da produção de alimentos se magnificaria (Mendonça de Barros, 1983).

Ocorre, contudo, que o que se seguiu com a produção agrícola brasileira reverteria, em boa medida, a tendência apresentada ao longo dos anos 70. No decorrer dos anos 80 e 90 as fontes de crescimento da agricultura seriam bastante distintas daquelas do passado.

\section{2 - A agricultura brasileira nos anos 80 e 90 .}

O traço marcante do padrão de crescimento da produção agrícola ao longo dos anos 80 e 90 não é tanto seu resultado absoluto, mas sim, o relativo. Entre 1980 e 1990 o PIB da agropecuária elevou-se em 28,2\%, enquanto o PIB total aumentou 3,84\%. Esse crescimento representa uma taxa média anual de 2,5\% a.a. para a agropecuária e apenas 0,38\% a.a. para a indústria (Ferreira Filho, 1997). Essa taxa de expansão representa uma redução no ritmo de crescimento da agricultura em relação a décadas anteriores, mas dado o baixo padrão de crescimento da economia decorrente da deterioração macroeconômica do país, esse desempenho foi considerado por alguns analistas como surpreendente (Rezende e Buainain 1994, Goldin e Rezende1993, Ferreira Filho 1997).

É interessante notar também que o aumento da oferta agrícola no período se deu em um ambiente de queda dos preços agrícolas frente aos industriais. Ferreira Filho (1994) mostra que a contribuição média do setor agrícola brasileiro para o deflator implícito do PIB foi decrescente no período. Homem de Melo (1992) calcula que a 
perda nos termos de troca do setor foi equivalente a $1,37 \%$ a.a. no período compreendido entre 1978 e 1991.

Quando se procura estudar o desempenho da agricultura nos anos 80 e 90, chamam atenção os ganhos de produtividade que ocorreram no setor como um todo. Desagregando-se a produção total entre exportáveis e domésticos, é possível perceber que os dois grupos apresentaram dinâmica semelhante quanto ao aumento da produtividade da terra. Silva (1991) calcula que nos anos 80 o rendimento físico dos exportáveis cresceu à taxa de $2,8 \%$ a.a., enquanto os domésticos expandiram à taxa de $2,6 \%$ a.a. ${ }^{6}$ : O autor comenta que essa taxa é quase quatro vezes maior do que aquela encontrada pelo mesmo para os anos 60 e $70(0,71 \%)$. '́́ curioso observar que durante todo o período esses dois grupos passam a apresentar desempenho semelhante, diferentemente do passado:

Chama atenção também o padrão de evolução da área cultivada. A figura 1 apresenta a evolução da área cultivada. Pode-se notar que existe um aumento na área cultivada até meados dos anos 80 , mas ao se adentrar os 90 , ela retorna aos mesmos níveis do início dos anos 80.

\footnotetext{
${ }^{6}$ Os ganhos de produtividade da terra apresentados pela agricultura brasileira estão compatíveis com a média mundial dos últimos 40 anos. Mitchell et al.. (1997) afirmam que entre 1950 e 1990 a produtividade da terra cresceu $2,17 \%$ a.a. no bloco dos países subdesenvolvidos e 2,39\% a.a. nos desenvolvidos.
} 


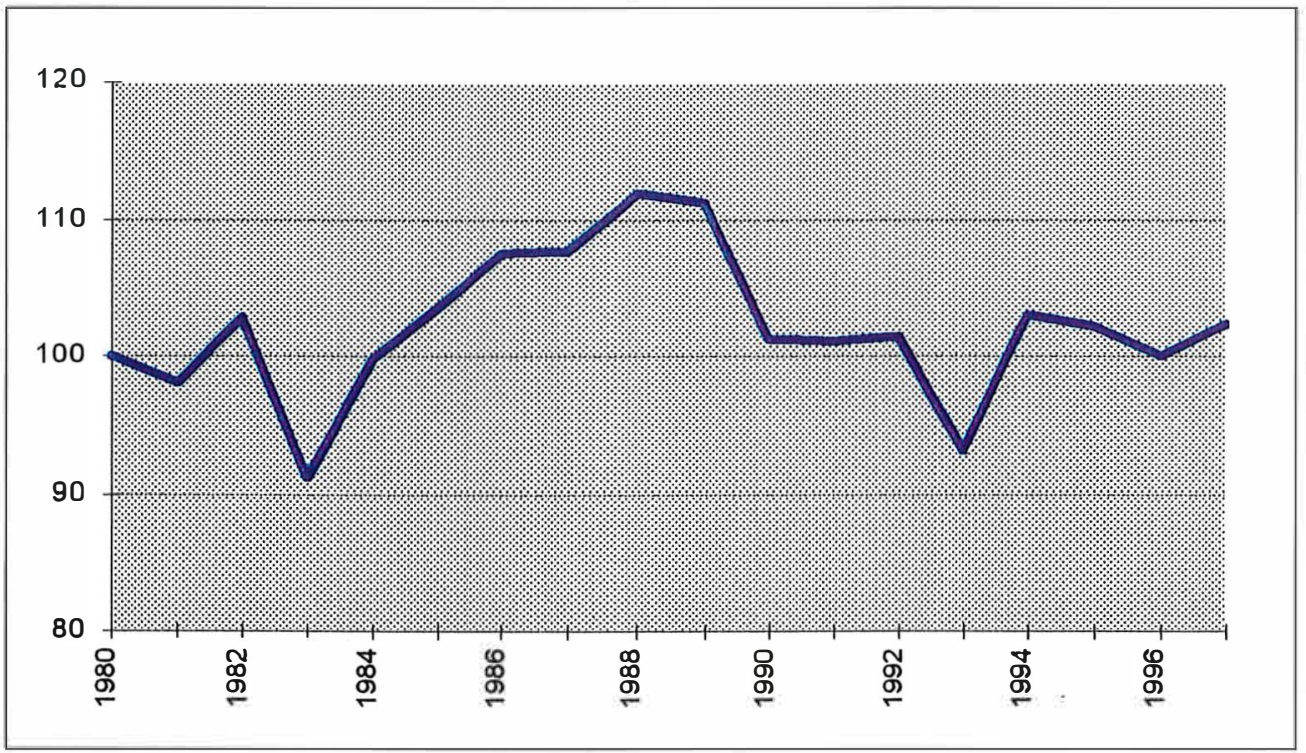

Figura 1 - Índice de Evolução da Área Cultivada com Lavouras Anuais e Permanentes, Brasil, 1980-1996 $(1980=100)$

Fonte : IBGE

Há que se ter cautela ao analisar as fontes de crescimento na agricultura. Como chama atenção Christensen (1975), as medidas de produtividade parciais (terra e trabalho) são insuficientes para caracterizar o desempenho agregado do setor. Faz-se necessário comparar o produto total com o uso combinado de todos os recursos. Por vezes o aumento da produtividade de um fator encontra-se associado à redução da produtividade de outro qualquer. Assim, por exemplo, é perfeitamente possível que em resposta ao aumento do preço de um fator ocorra maior procura por outro que lhe seja substituto. Pensando em termos de uma isoquanta unitária, alterações nos preços relativos de um fator são representadas como variações na inclinação da linha de preços, indicando a mudança no nível ótimo de utilização dos insumos (Bonelli e Pessoa -1998). Dessa maneira, percebe-se que menor uso de um fator pode estar escondendo maior uso de outro. 
Em recente trabalho Gasques e Conceição (1998) calculam as taxas anuais de crescimento das produtividade totais e parciais na agricultura brasileira. Os autores estimam que entre 1976 e 1994 a produtividade total dos fatores aumentou 3,38\% a.a.; a produtividade da terra $3,79 \%$ a.a. e a do trabalho $4,02 \%$ a.a..

Esses números são bastante significativos quando se compara com o comportamento da produtividade total dos fatores (PTF) da agricultura em diferentes países. Rosegrant e Evenson (1992) estudando alguns países do sul da Ásia, calcularam que entre 1957 e 1985 a PTF aumentou às taxas de 1,01\%,0,78\% e 1,07\% a.a. na Índia, em Bangladesh e no Pakistão, respectivamente. Jorgenson e Gollop (1992) apresentaram resultados referentes aos Estados Unidos: entre 1947 e 1985 a produtividade total dos fatores cresceu à taxa de 1,58\% a.a.; entre 1979 e 1985 esse número atingiu 3,58\% a.a. Fantine e Veeman (1994), citados por Gasques e Conceição (1998), estimam que entre 1948 e 1991, a PTF elevou-se 1,88\% a.a. no Canadá. No caso australiano, Mullen e Cox (1996) chegam a uma taxa de crescimento da PTF de 2,5\% a.a.. Por fim, Kalirajan et al. (1996) mensura que entre 1970-1978 a PTF decresceu à taxa de 5,6\% a.a. na China; entre 1978 e 1984 aumentou para 7,7\% a.a., caindo para uma taxa positiva de 2,8\% a.a. entre 1984 a 1987.

Vale ressaltar, também, que o desempenho superior da agropecuária frente à indústria no Brasil dos anos 80 deu-se em um ambiente de maior exposição do setor agrícola ao mercado internacional. Como apontam Manoel e Mendonça de Barros (1987), a proporção do valor do produto exportado sobre o valor da produção total, em preços constantes de 1962, aumentou desde o final dos anos 70 até meados dos 80 . A tabela 3 atualiza os dados apresentados por esses autores. Pode-se observar que, apesar de reduções na parcela exportada em 1986, 1988 e'1991, ocorreu uma abertura maior e 
mais consistente a partir de 1993 , atingindo quase $24 \%$ do valor total produzido pela agricultura $^{7}$.

Tabela 3 - Relação entre o Valor do Produto Agrícola Exportado e Valor do Produto Agrícola Total, Brasil, 1970-1996.

\begin{tabular}{lc}
\hline Ano & \% do Produto Exportado \\
\hline 1970 & 0,154 \\
1971 & 0,146 \\
1972 & 0,173 \\
1973 & 0,190 \\
1974 & 0,160 \\
1975 & 0,184 \\
1976 & 0,199 \\
1977 & 0,178 \\
1978 & 0,176 \\
1979 & 0,159 \\
1980 & 0,194 \\
1981 & 0,236 \\
1982 & 0,209 \\
1983 & 0,249 \\
1984 & 0,240 \\
1985 & 0,231 \\
1986 & 0,187 \\
1987 & 0,210 \\
1988 & 0,178 \\
1989 & 0,205 \\
1990 & 0,219 \\
1991 & 0,185 \\
1992 & 0,212 \\
1993 & 0,238 \\
1994 & 0,238 \\
1995 & 0,237 \\
1996 & 0,237 \\
\hline
\end{tabular}

Fonte: Os dados de produção são do IBGE. Os dados de exportação, da CACEX.. Os resultados apresentados foram calculados fazendo-se uso de um Índice de Laspeyres, tendo como período base o ano de 1962. Computa-se toda a produção nacional bem como aquilo que é exportado. Todos os produtos processados são convertidos em valores equivalentes ao produto in natura, de tal sorte que é possível avaliar perfeitamente quanto do que se produz internamente é consumido no exterior.

7 Vale ressaltar, entretanto, que os cálculos apresentados não levam em conta o produto importado. Sabe-se que o ideal seria medir o coeficiente de abertura somando-se as exportações com as importações. De qualquer forma os resultados servem para indicar uma tendência de aumento da colocação do produto interno no exterior. 
O maior grau de abertura ao exterior sinalizava, ainda segundo Manoel e Mendonça de Barros (1987), que o padrão de consumo doméstico estaria progressivamente se internacionalizando. Os autores vão além e ao discorrerem acerca da distinção entre produtos domésticos e exportáveis, indicam que a mesma estaria perdendo sentido no horizonte que se desenhava. O maior grau de exposição ao exterior associado à redução das políticas públicas voltadas para a agricultura, que acabava por liberar progressivamente os mercados agrícolas, seriam um indutor a um maior equilíbrio entre os dois grupos de produtos.

Seja como for, o fato é que esses estudos mais recentes dão conta de um padrão de crescimento equilibrado entre a maior parte dos produtos agrícolas. Note-se, também, que a agricultura brasileira conseguiu crescer a despeito do maior grau de concorrência no mercado internacional.

Outro ponto que merece ser levantado é que os ganhos de produtividade alcançados pelo setor agrícola ocorreram concomitantemente com a redução dos volumes de recursos transferidos ao setor. Como apontam Buainain e Rezende (1994), a linha de política econômica adotada nos anos 70 tinha como preocupação central promover o crescimento da economia brasileira a qualquer custo, sem apresentar maiores preocupações com o equilíbrio e sustentabilidade das contas nacionais. Segundo os autores, desde o início dos anos 80, a política macroeconômica foi perdendo graus 'de liberdade, passando então a concentrar esforços no equilíbrio macroeconômico. Essa alteração na rota da política econômica teria como consequiência a redução dos volumes de recursos subsidiados fornecidos à agricultura. Segundo Dias (1993):

"A crise fiscal e financeira do governo federal durante a década de 80 foi limitando gradualmente a sua capacidade de transferir renda e, consequentemente, de coordenação de políticas setoriais." (página 888)

A magnitude da redução da interferência do governo central no setor pode ser observada com auxílio da figura 2. Nela, é apresentada a relação entre o volume total de 
crédito formal concedido e o PIB agropecuário. Note-se que o programa atingiu seu auge em 1976 quando começou a declinar, muito embora ainda se sustentasse em patamares elevados por mais alguns anos.

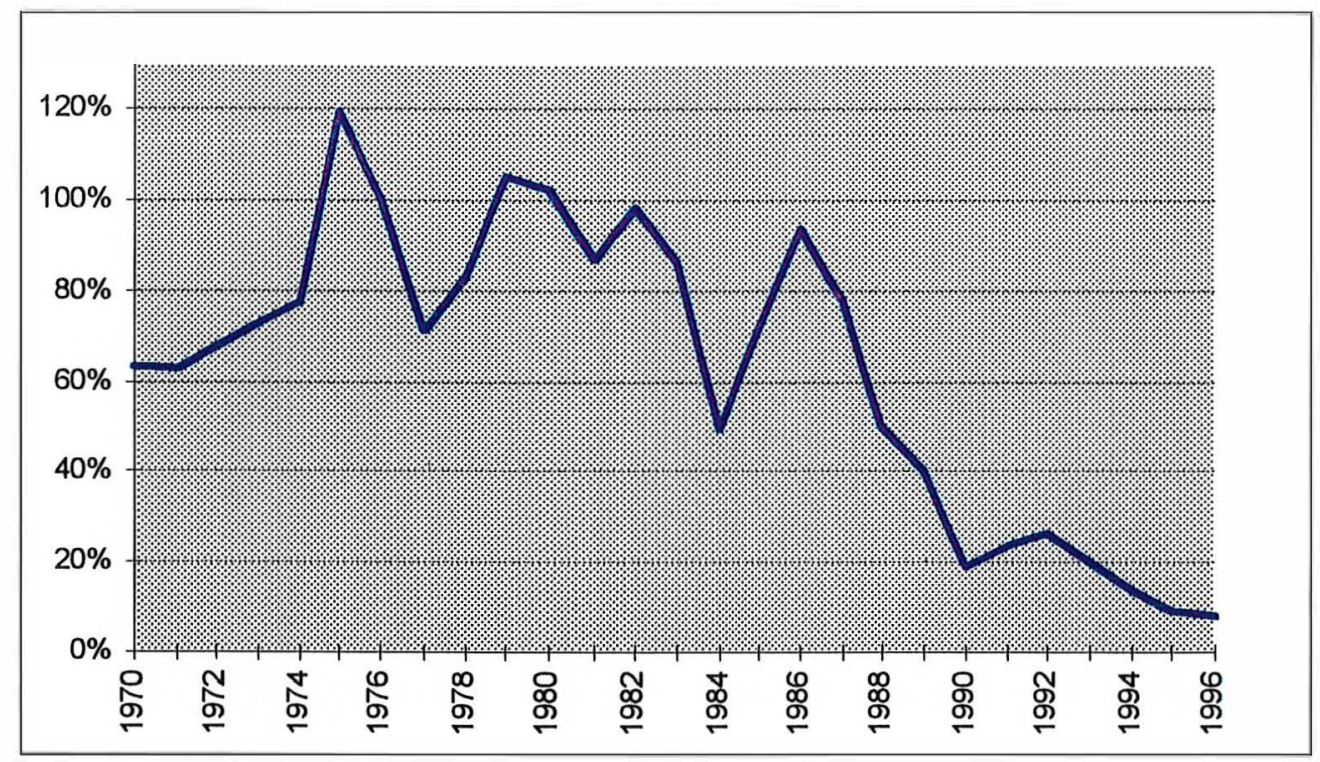

Figura 2 - Relação entre Crédito Formal e PIB Agropecuário, Brasil, 1970$1996(\%)$

Fonte: Os dados de crédito foram retirados de Almeida (1996). Os dados do PIB agropecuário do BACEN.

Percebe-se uma quebra estrutural na tendência da série no ano de 1986 quando, a partir de então, o Sistema Nacional de Crédito Rural perdeu a importância de outrora. Vale lembrar que, como apontam Araújo e Meyer (1979), Dias (1988) e Mendonça de Barros e Manoel (1987), a política de crédito rural era o elemento central da política agrícola. Dessa maneira pode-se dimensionar a partir da tendência observada na série, quão significativa foi a redução no grau de intervenção da política governamental. 
Ora, quando se soma o quadro de desajuste macroeconômico pelo qual passou o país ao maior grau de concorrência do mercado internacional, à redução nos subsídios concedidos ao setor e à perda na relação de troca sofrida ao longo dos anos 80 , coloca-se a seguinte questão: como foi possível ao setor crescer e tornar-se mais produtivo em condições tão adversas? A seção seguinte procurará condensar algumas proposições levantadas em diversos estudos a fim de responder esta questão. O presente trabalho, por seu turno, tem como pano de fundo essa mesma pergunta.

\section{3 - Agricultura e ciclos econômicos}

Em uma seqüência de artigos, Rezende $(1986,1988,1989 a, 1989 b)^{8}$ elenca um conjunto de proposições quanto ao comportamento da agricultura nos ciclos econômicos. A principal preocupação do autor era encontrar explicação para a pequena variação da oferta agrícola com os movimentos da economia brasileira. Como já foi cōmentado, o autor percebia que a recessão ocorrida nos anos 80 não afetou tanto a agricultura quanto a indústria.

Rezende vai procurar explicação em antigos estudos acerca do problema. Com efeito, a constatação da baixa elasticidade da oferta agrícola era um fenômeno bem estudado desde a Grande Depressão. Schultz (1945), em seu livro Agriculture in an Unstable Economy, aventa algumas hipóteses para explicar o comportamento da oferta agrícola nos ciclos econômicos. O autor constata que no curto prazo existe flexibilidade da oferta apenas para cima: preços altos induzem uma expansão da oferta, mas preços baixos não forçam a uma contração proporcional da mesma. Schultz acrescenta que mesmo o aumento da oferta leva 2 a 3 anos para se concretizar uma vez que sendo os

\footnotetext{
${ }^{8}$ As principais idéias dos referidos artigos encontram-se resumidas em Goldin e Rezende (1993).
} 
recursos produtivos quase que totalmente empregados, fica difícil imaginar que possam prontamente aumentar a oferta ${ }^{9}$.

A baixa flexibilidade da oferta deve-se, ainda segundo Schultz (1945), a dois fatores fundamentais, quais sejam: i) estrutura competitiva da agricultura; ii) alta participação dos custos fixos nos custos totais. O primeiro ponto refere-se ao fato de o agricultor individual ser um tomador de preços, ou seja, uma alteração no seu volume de produção não afeta o preço de equilíbrio de mercadó $^{10}$. Dessa maneira, não existe condição de aumentar a renda em um período de preços baixos senão elevando ainda mais a oferta. Cortar a produção não confere ganho algum ao produtor. De certa maneira a estrutura competitiva do setor "forçaria" ao uso intensivo dos fatores de produção.

A alta proporção dos custos fixos nos custos totais de produção também induz ao uso pleno dos fatores de produção. Esses custós são mantidos independentemente do montante produzido pela firma. Schultz afirma que a maior parcela dos custos de produção refere-se a mão-de-obra (cerca de 70\% no caso dos EUA nos anos 30 e 40). Como boa parte dessa força de trabalho é composta por proprietários e, em um ambiente de recessão, o emprego nos demais setores também é contraído, não há como reduzir os custos fixos de produção. Outro ponto levantado pelo autor diz respeito ao uso da terra. Muito embora o custo do aluguel ("rent") da terra possa cair em uma contração da economia, a áréa cultivada tende a ser mantida em decorrência dos ganhos de produtividade que as novas tecnologias proporcionam ${ }^{11}$.

\footnotetext{
${ }^{9}$ É importante chamar atenção para ressalva que o autor faz quanto as transformações tecnológicas no setor. Segundo Shultz o aumento no uso de insumos modernos atenuaria a baixa elasticidade da oferta de fatores no curto prazo, conferindo maior agilidade à oferta agrícola.

${ }^{10}$ Vale a pena transcrever um trecho da página 93 de Schultz (1945):

"Quando a demanda pelo produto agrícola se contrai, não está sob poder do fazendeiro tornar a produção agregada variável e tratar seu preço de venda e seu "salário" como constantes. Com a oferta agrícola mantendo-se aproximadamente constante, uma contração na demanda faz com que os preços caiam a menos que o governo intervenha." (nossa tradução)

${ }^{11} \mathrm{~A}$ importância dos ganhos de produtividade na dinâmica da agricultura será objeto da próxima seção.
} 
Johnson (1950) parece não concordar que os custos fixos sejam a explicação fundamental para a estabilidade da oferta agrícola. Segundo o autor esta característica deve-se muito mais a elasticidade da oferta dos fatores de produção. Para ele o emprego constante dos fatores de produção refletem não os custos fixos mas: i) curvas de oferta inelásticas de fatores associadas a preços de fatores bastante flexíveis; ii) mudanças nos custos de oportunidade dos fatores com o ciclo de negócios. A primeira explicação refere-se mais ao capital físico e à terra; a segunda, ao trabalho.

Em um mercado onde as curvas de oferta dos fatores são inelásticas e os preços flexíveis há uma tendếncia ao uso intensivo dos fatores de produção. Tome-se por exemplo o caso da terra. Em uma contração da demanda, dada a inelasticidade-preço da mesma com relação aos produtos agrícolas, o preço das commoditties cai mais do que proporcionalmente. A queda no preço do produto induz uma redução no uso dos fatores de produção. Como a oferta de terras é inelástica e seu uso alternativo inexistente, o ajuste do mercado se dá com o preço do aluguel caindo mais do que proporcionalmente a queda na demanda. Os preços dos fatores de produção ajustam-se aos menores preços dos produtos e, dessa maneira, tendem a ser empregados plenamente.

O mesmo ocorreria com o capital. A função de oferta de máquinas e equipamentos para a agricultura como um todo é bastante inelástica sempre que o preço de equilíbrio da demanda estiver abaixo do preço dos equipamentos novos. A curva de oferta passa entắo a depender, apenas, da oferta existente de máquinas usadas. Como esse custo não representa desencaixe imediato, pode perfeitamente ser postergado. Dessa maneira o preço do capital também se ajusta para baixo e, como a terra, tende a ser plenamente empregado.

No tocante à mão-de-obra, Johnson parte da constatação que o montante de trabalhadores assalariados empregados na produção agrícola não oscilou significativamente ao longo de toda a Grande Depressão. Observa, portanto, que mesmo a porção variável dos custos de produção, referente à mão-de-obra contratada, tendeu a ser plenamente empregada. Assim não é possível sustentar que a explicação para baixa 
elasticidade da oferta é a alta proporção de custos fixos nos custos totais. A razão para a sustentação do emprego é que o custo marginal de oportunidade da mão-de-obra cai, uma vez que o emprego urbano diminui no ciclo de baixa. Conforme o custo marginal de oportunidade se aproxima de zero, a curva de oferta de trabalho agrícola torna-se bastante inelástica. Da mesma maneira que o capital e a terra, o ajuste se dá via redução drástica de preços. Os trabalhadores prefeririam taxas mais baixas de salário ao desemprego. Pode-se notar que, neste ponto particular, Johnson concorda com Schultz.

Para esses dois autores a diferença de velocidade dos ajustamentos da oferta na agricultura e na indústria faz com que os termos de troca entre os setores mudem substancialmente conforme o padrão dos ciclos. Em uma recessão, os preços agrícolas caem mais do que os industriais, uma vez que neste último segmento é possível ajustar a oferta assegurando, assim, a manutenção dos preços. Em um ciclo de alta da economia, o inverso sucede: como a oferta agrícola é mais lenta e a demanda é preçoinelástica, o ajuste no setor se dará através do aumento dos preços; a indústria, por sua vez, adequa rapidamente sua produção, mantendo relativamente estável seu nível de preços. O resultado desses processos de ajustamento pode então ser resumido: em ciclos de baixa os termos de troca seguem contrários à agricultura; no ciclo de alta o setor agrícola melhora sua relação de troca. Vale notar que a agricultura serve como um colchão principalmente na recessão, uma vez que além de sustentar o nível de emprego, garante, em alguma medida, o poder de compra do salário urbano.

Através das formulações teóricas propostas por Schultz (1945) e Johnson (1950), Rezende $(1986,1988,1989$ a , 1989b) procura entender o bom desempenho relativo da agricultura frente a indústria nos anos 80. A principal explicação apresentada pelo autor é que em decorrência do baixo desempenho da economia como um todo, o nível de emprego reduziu-se, baixando o custo marginal de oportunidade do trabalho. Assim, em razão da estabilidade do emprego rural, foi possível elevar a produção agrícola. Como aponta Rezende (1986), nos anos 70 a situação era exatamente oposta pois a economia crescia a taxas substanciais; o que acabava por drenar recursos do setor, reduzindo a oferta agrícola: $\mathrm{O}$ impacto das flutuações do emprego se daria, segundo o mesmo, 
principalmente sobre a pequena produção pois é aí que se faz sentir mais fortemente o custo de oportunidade do emprego urbano. Surge assim uma explicação adicional para o desempenho relativo dos produtos domésticos face aos exportáveis. É que, como sustenta Rezende (1988), a maior parte dos produtos de mercado interno era, até 1985 , produzida pelos pequenos e médios produtores e arrendatários. Logo, com as oscilações da economia e com as migrações inter-setoriais do emprego, haveria uma variação maior na produção dos bens domésticos. Nos anos 80 o aumento do número de pequenos proprietários e arrendatários expliçaria a elevação da quantidade ofertada de produtos de mercado interno (Rezende 1988).

Outro aspecto levantado por Rezende (1989b) diz respeito ao papel desempenhado pela economia internacional. O autor lembra que parcela crescente da produção nacional sofria influência dos preços externos. Uma vez que os ciclos internacionais podem apresentar movimentos diferentes dos internos, o padrão de crescimento dos setores ligados ao comércio internacional pode ser bastante distinto dos demais. O mesmo ocorreria com os insumos modernos usados na agricultura. Dada a alta dependência desses insumos ao preço do petróleo, a formação de preços nesses mercados seria determinada exógenamente. Dessa maneira conclui Rezende (1989b):

“... a acumulação de capital na agricultura tanto pode ser anticíclica como pró-cíclica dependendo da atuação das variáveis externaś..." (página 575)

Nas proposições colocadas por Rezende pode-se notar uma preocupação maior em descrever o comportamento da agricultura no curto prazo, procurando discorrer acerca dos impactos das mudanças ano a ano na política econômica sobre o setor (Ferreira Filho, 1997). O autor não centra sua análise na persistência do crescimento da agricultura. Tampouco explica os sustentados ganhos de produtividade que ocorreram desde o início dos anos 80. Para melhor entender esse fenômeno há que se deslocar a ênfase do componente de ciclo para aquele de tendência das séries 
econômicas. A preocupação central passa a ser então conhecer a fundo os ajustamentos estruturais porque passou a agricultura no referido período.

\section{4 - O ajustamento estrutural da agricultura brasileira nos anos 80}

Ao captarem os sinais das mudanças no padrão de crescimento de agricultura brasileira, alguns autores passaram a aventar a hipótese de que o que vinha acontecendo, de fato, era um ajustamento estrutural do setor às mudanças por que passava a economia brasileira. Os movimentos simultâneos de abertura da economia e restrição de recursos acabaram por forçar o aumento da eficiência produtiva. A retirada dos subsídios implícitos no crédito rural teria alterądo os preços relativos dos fatores, forçando uma realocação dos mesmos em direção a seu uso mais eficiente. A elevação da produtividade seria decorrente do uso mais racional dos fatores e da disseminação dos resultados da pesquisa agronômica dos anos precedentes.

O trecho abaixo, extraído de Dias (1988), resume esse conjunto de idéias:

"Essa é uma représentação consistente de um sistema que está respondendo ao processo de ajustamento com métodos de racionalização da produção, produtividade crescente e, por fim, competitividade nos mercados internacionais. Esse padrão também condiz coin a hipótese de que o crescimento potencial está sendo restrito pela escassez de investimento, à qual não é peculiar ao setor rural, estendendo-se a toda a economia, como vimos na primeira seção deste artigo. Desde 1984 os gastos de investimento em maquinaria e fertilizantes vem sendo crescentes e provavelmente financiados pelos agricultores com uma parcela maior de seus próprios recursos, pois, embora o crédito de investimento tenha aumentado em 1986, sofreu substancial redução em 1987. “ (página. 266). 
Como afirmam Ferreira Filho (1997), Dias (1988, 1989) e Rezende (1989 a), o aumento na produtividade é explicado pela soma do uso mais racional dos fatores com a incorporação do progresso tecnológico gestado nos anos 70. Esses dois fatores teriam levado, conjuntamente, a uma redução nos custos unitários de produção, viabilizando, assim, o crescimento da oferta.

Ferreira Filho (1997) aponta que esses podem ser, de fato, alguns dos componentes que explicam as reduções nos custos de produção. $O$ autor leṿanta, entretanto, que outra razão para a queda nos custos, qual seja, a diminuição nos prèços dos fatores de produção. Partindo de uma série de custos de produção levantados pelo Instituto de Economia Agrícola do Estado de São Paulo (IEA) no período de 1980 a 1994, o autor estuda o comportamento dos mesmos para as lavouras do milho, arroz, feijão, algodão, mandioca, soja e trigo. A diminuição dos custos unitários é bastante clara no período: partindo de um índice 100 em 1981, chega-se, em 1994, a um valor de 44 para o algodão, 43 para o arroz, 22 para o feijão, 37 para o milho, 59 para a mandioca e 57 para soja. Ou seja, na maior parte dos produtos houve queda de mais de $50 \%$ nos custos de produção.

A principal causa apontada para a redução dos custos de produção foram as quedas nos preços dos fatores. Como coloca Homem de Melo (1988), nos anos 80 houve queda nos preços de fertilizantes, defensivos e combustíveis. Apenas os preços das máquinas agrícolas mostraram tendência de alta. Como já comentado anteriormente, paralelamente a redução no preço dos fatores houve queda nos preços de quase todos os produtos agrícolas. Caberia saber, portanto, se a queda nos preços dos produtos seria suficiente para mais do que compensar as reduções nos custos médios.

A tabela 4, extraída de Ferreira Filho (1997, página 11), calcula a relação entre os preços recebidos e os índices de custo unitário. Encontra-se também apresentado o índice de termos de troca calculado pelo IEA. Pode-se observar que a despeito de variações para baixo em alguns anos, existe uma tendência de elevação da relação preço recebido/custo unitário, indicando melhora na situação econômica dos agricultores. A 
série é clara em mostrar que a margem aumentou sistematicamente no período. A única exceção é a cultura de mandioca que apresentou redução sistemática em suas margens. Outro aspecto que merece destaque é a evolução na relação de trocas do setor: houve, principalmente nos anos 90, uma sensível queda na relação preços recebidos/preços pagos (IPR/IPPF).

Tabela 4 - Índice de valor da relação preço do produto / custo unitário de produção e relação preços recebido / preços pagos por insumos de fora da propriedade rural. $(1980=100)$.

\begin{tabular}{cccccccc}
\hline Ano & Algodão & Arroz & Feijão & Milho & Mandioca & Soja & IPR/IPPF \\
\hline 1980 & 137 & 177 & 123 & 130 & 147 & 179 & 122 \\
1981 & 100 & 100 & 100 & 100 & 100 & 100 & 100 \\
1982 & 102 & 135 & 59 & 98 & 58 & 94 & 89 \\
1983 & 94 & 147 & 86 & 136 & 72 & 110 & 116 \\
1984 & 108 & 127 & 108 & 121 & 99 & 119 & 117 \\
1985 & 119 & 186 & 37 & 141 & 101 & 110 & 123 \\
1986 & 110 & 121 & 73 & 172 & 40 & 147 & 159 \\
1987 & 86 & 71 & 122 & 64 & 22 & 111 & 79 \\
1988 & 96 & 80 & 81 & 99 & 101 & 78 & 98 \\
1989 & 47 & 59 & 122 & 81 & 56 & 59 & 66 \\
1990 & 57 & 84 & 86 & 82 & 21 & 49 & 69 \\
1991 & 61 & 122 & 144 & 114 & 19 & 78 & 66 \\
1992 & 82 & 107 & 138 & 142 & 47 & 94 & 71 \\
1993 & 148 & 172 & 252 & 204 & 75 & 125 & 85 \\
1994 & 108 & 112 & 216 & 114 & 46 & 86 & 92 \\
\hline
\end{tabular}

Fonte : Ferreira Filho (1997)

A combinação de piora nos termos de troca com melhora na relação preço do produto/custo médio dá alguma indicação de ter ocorrido incorporação de progresso tecnológico. Na realidade, embora o autor estivesse interessado em demonstrar apenas o efeito da redução dos preços dos insumos sobre os custos médios, fica bastante difícil isolar o efeito da tecnologia sobre os mesmos. Por um lado, como menciona o próprio autor, o IEA atualiza seus coeficientes técnicos sistematicamente a fim de dar conta das mudanças tecnológicas ocorridas na produção. Por outro, no cálculo do custo médio 
encontra-se embutida a produtividade da lavoura que, por sua vez, sofre influência do progresso tecnológico. Assim, embora seja difícil separar os efeitos dos preços dos insumos do progresso tecnológico, pode-se afirmar concretamente que ocorreram reduções nos custos médios de produção.

Esse movimento de diminuição nos custos unitários é, na realidade, uma tendência de longo prazo comum a agricultura de todos os países desenvolvidos. Em estudo sobre a história da agricultura americana, Cochrane (1993) faz uso de um engenhoso modelo por ele desenvolvido, em 1958, para entender o crescimento da oferta agrícola naquele país. Baseando-se na teoria formulada por Schumpeter (1936), o autor procura explicar o aumento persistente da produtividade da terra observada nos Estados Unidos. O modelo foi por ele batizado de "treadmill"

O modelo inicia qualificando os agricultores em três grupos distintos, conforme sua aversão ao risco. No primeiro encontram-se os mais modernos, amantes do risco e dispostos a adotar novas tecnologias. Do segundo grupo fazem parte aqueles agricultores que aguardam para tomar a decisão quanto a adoção da nova tẹcnologia, esperando os resultados do grupo mais moderno. O terceiro grupo é constituído pelos agricultores que, ou por ausência de capital humano para adotar a nova tecnologia, ou por falta de recursos para investir, não faz uso da mesma.

Partindo-se de uma posição de equilíbrio a dinâmica do sistema será dada pela adoção de tecnologia por parte dos agricultores mais modernos. Esses vislumbram a possibilidade de ampliar suas margens de lucro: embora os custos totais aumentem com os novos investimentos, a elevação da produtividade decorrente da nova tecnologia garantirá a redução nos custos unitários. Como esse grupo é pequeno em número, o aumento da oferta graças à nova tecnologia é insuficiente para abaixar os preços de mercado. Dessa maneira, mantidos os preços, a redução nos custos unitários assegura o aumento na margem de lucro dos agricultores modernos.

\footnotetext{
12 Parece não existir uma tradução específica para o termo. Treadmill era uma bomba d'água movimentada pelos passos do fazendeiro sem que esse saísse do lugar. A idéia a ser transmitida é a de o agricultor que anda mas não sai do lugar. Ver Veiga (1991) a respeito do assunto.
} 
Os fazendeiros do grupo intermediário, por seu turno, ao vislumbrarem o potencial de ganho adicional, passam a adotar a nova tecnologia. Ocorre, contudo, que conforme um número crescente de agricultores vai elevando sua produção, a oferta agregada vai progressivamente aumentando. Mantida constante a demanda por alimentos, o preço dos mesmos passa a cair em decorrência da oferta maior. Chega-se, então, a um novo ponto de equilíbrio onde fica consolidada a seguinte situação: i) o preço de equilíbrio está abaixo do nível inicial; ii) com a queda do preço, a margem de lucro volta a ser zero (equilíbrio competitivo) tanto para o grupo moderno, quanto para o intermediário; iii) os produtores mais atrasados, na medida em que não fizeram uso da nova tecnologia, mantém seus custos unitários no mesmo nível da situação inicial. Dessa maneira, não conseguem cobrir seus custos de produção, uma vez que o nível de preços baixou. Com o tempo, são forçados a deixar a produção. Os produtores mais dinâmicos acabam por anexar a área daqueles que abandonam a produção. Note-se que com a redução dos preços, os lucros voltam a zero; somente com novas inversões em tecnologia moderna haverá aumento temporário do lucro. Os agricultores terão que investir sistematicamente em novas tecnologias para seguir produzindo, com seus lucros sempre tendendo a zero. Os produtores andam mas ficam no mesmo lugar. No longo prazo os únicos ganhadores do processo serão os consumidores. Os perdedores, aqueles expulsos da produção.

O modelọ de Cochrane (1993) parece explicar bem a dinâmica da agricultura americana. Se esse modelo se adequa às transformações por que vem passando a agricultura brasileira é uma questão que merece ser estudada empiricamente. Seja como for, alguns elementos essenciais do modelo parecem encaixar com os trabalhos citados anteriormente. Vale a pena, entretanto, extrair do modelo de Cochrane dois aspectos fundamentais que garantem o funcionamento do mesmo. Em primeiro lugar a existência de capital para viabilizar os novos investimentos é condição inicial para a dinâmica de todo o sistema. Segundo, os aumentos de produtividade advindos do progresso tecnológico e dos ganhos em escala são a única forma de assegurar a redução sistemática dos custos médios, garantindo assim a permanência na produção. No longo 
prazo são esses os determinantes fundamentais do crescimento da agricultura. O presente trabalho procurará dimensionar o que vem ocorrendo com a formação de capital na agricultura brasileira. A fim de tornar mais claros os objetivos do estudo fazse necessário tecer algumas observações acerca dos determinantes do crescimento econômico.

\section{5 - Os determinantes do crescimento}

É difícil falar de crescimento econômico sem tocar no nome de Robert Solow. Seu modelo é o ponto de partida de toda a moderna teoria do crescimento ${ }^{13}$. Com uma seqüência de artigos de 1956 e 1957, Solow construiu os alicerces para o entendimento dos fatores que explicam o crescimento de um país no longo prazo. Na presente seção não será feita uma exposição do modelo original por ser ele suficientemente conhecido. Procurar-se-á, por hora, apresentar apenas uma síntese dos fatores que afetam o crescimento econômico, a fim de facilitar a compreensão dos objetivos específicos do estudo ora apresentado ${ }^{14}$.

O esquema de contabilidade proposto por Solow $(1957)^{15}$ parte de uma função de produção com retornos constantes à escala. Seja $\mathrm{Q}$ o produto agregado da economia que é função da quantidade de capital (K), da força de trabalho (L) e de uma taxa exógena de progresso tecnológico (A). Pressupõe-se que as mudanças tecnológicas são neutras no que se refere as alterações na produtividade marginal do capital (PMgK) e do trabalho (PMgL). Assim, mudanças em A causam alterações equânimes em PMK e PML. A equação (2.1) estabelece a relação funcional entre as variáveis:

\footnotetext{
${ }^{13}$ Ver, por exemplo, Barro e Sala-i-Martin (1995) e Romer (1996).

${ }^{14}$ Para melhor exposição do modelo de Solow ver seu excelente livro de 1970, intitulado Growth Theory.

${ }^{15}$ No capítulo 4 será feita uma exposição do esquema contábil desenvolvido pelo autor.
} 


\section{(2.1) $Q=A \cdot F(K, L)$}

Diferenciando totalmente o sistema e realizando uma sequência de substituições, ver Solow (1957), chega-se ao seguinte esquema contábil:

(2.2) $\mathrm{q}=\mathrm{a}+\mathrm{s}_{\mathrm{k}} \mathrm{k}$

onde,

$$
\begin{aligned}
& q=\text { taxa de crescimento do produto por trabalhador } \\
& \mathrm{a}=\text { taxa de progresso tecnológico } \\
& \text { sk = participação do capital no produto total } \\
& \mathrm{k}=\text { taxa de crescimento do capital por trabalhador }
\end{aligned}
$$

A equação (2.2) indica que a taxa de aumento do produto por trabalhador (q) é função do progresso tecnológico e da taxa de aumento do capital por trabalhador (k), ponderado pela participação do capital no produto total $\left(\mathrm{s}_{\mathrm{k}}\right)$. Assim as variáveis explicativas do aumento no produto per capita seriam a acumulação de capital e o avanço da técnica. Note-se que a variável (a) não é mensurável; na realidade ela pode ser obtida apenas por diferença. Rearranjando os termos em (2.2) tem-se,

$$
\left(2.2^{\prime}\right) \quad a=q-{ }^{-} s_{k} k
$$

O termo (a) representa a produtividade total dos fatores e é também conhecido por resíduo de Solow. Boa parte da teoria de crescimento desenvolvida após a apresentação deste modelo procurou entender quais as variáveis que afetam o resíduo. Como aponta Blanchard e Fisher (1989), até hoje tem-se um conhecimento apenas limitado de onde vem o resíduo e porque ele é maior em alguns países do que em outros, ou, ainda, é maior durante alguns períodos de tempo do que em outros. Essa dificuldade decorre do fato de o próprio conceito de tecnologia ser abstrato por natureza 
(Mundlak, 1989). A engenhosidade de Solow foi a de contornar o problema concentrando-se nas variáveis passíveis de mensuração.

Ocorre que em alguns estudos empíricos constatou-se que o resíduo acabava por explicar a maior parte do crescimento. Solow (1957) calcula que nos EUA, no período de 1909 a 1949, cerca de $12 \%$ da taxa de crescimento da economia foi explicado pelo capital e $88 \%$ pelo resíduo. Denison (1985), corroborando os números acima apresentados, estima que entre 1929 e1982 o capital explicou 15\% do crescimento daquele país . Em revisão acerca do assunto, Chenery (1983) encontra que a contribuição do resíduo ao crescimento é, de fato, substancial . Para países desenvolvidos o resíduo constituía mais da metade da taxa de crescimento. Nos países em desenvolvimento, entretanto, a proporção do crescimento explicada pelos fatores de produção (capital e trabalho) encontrava-se acima de $3 / 4$, com o resíduo respondendo por menos de 25\%. Elías (1992) estudando 7 países latino-americanos conclui que o poder de explicação do resíduo é bastante variável na amostra, no período de 1950 a 1980 . O resíduo explicava $21 \%$ do crescimento na Argentina , 57\% no Brasil, -6\% no Chile, $42 \%$ na Colômbia, $48 \%$ no México, $41 \%$ no Peru e, finalmente, $50 \%$ na Venezuela.

A importância relativa do resíduo, bem como sua variância entre diferentes países, levou diversos pesquisadores a procurar entender e destrinchar os componentes que afetam a produtividade total dos fatores. Nos últimos 40 anos foram inúmeras as ramificações désenvolvidas nos estudos teóricos e empíricos sobre o crescimento econômico no longo prazo. Discorrer sobre cada uma delas seria tarefa desnecessária para os propósitos deste trabalho. É possível, contudo, realizar alguma sistematização do que é hoje quase consensual entre os estudiosos dessa área da economia.

Segundo Stern (1991) seriam 6 os principais determinantes do crescimento econômico: i) acumulação de capital; ii) capital humano; iii) pesquisa , desenvolvimento e inovação; iv) capacidade administrativa e organizacional; v) infraestrutura; e, vi) alocação do produto diretamente para os setores produtivos. Dentre esses fatores aquele que mereceu maior atenção nos últimos anos foi a importância da 
dotação de capital humano para explicar o crescimento no longo prazo. Desde logo, notou-se a forte correlação entre o volume de pesquisa, desenvolvimento e inovação com a quantidade de capital humano existente nas economias. Diversos estudos econométricos deram conta, já há algum tempo, da importância do grau de escolaridade e do treinamento da mão-de-obra para a elevação da produtividade do trabalho. Foi só recentemente, contudo, que a teoria do crescimento incorporou o capital humano nos modelos de crescimento. A partir dos trabalhos de Romer (1986), Romer (1990), Lucas (1988), houve um aumento expressivo no interesse dos pesquisadores em estabelecer teórica e empiricamente a importância do capital humano para o crescimento. A idéia básica que envolve os modelos acima citados é a dos retornos crescentes advindos do acúmulo de capital humano: dadas as externalidades positivas geradas no processo de formação de capital humano, quanto maior o estoque acumulado, maiores serão os efeitos externos criados, garantindo retornos crescentes ao investimento em educação. Não só o aprendizado formal é importante mas também o prático. Em artigo original, Arrow (1962) ${ }^{16}$, antecipando os modelos desenvolvidos a partir de meados dos 80, constrói um modelo em que os ganhos de produtividade do trabalho são decorrentes do aprendizado adquirido com o tempo de trabalho ("learning-by-doing") ${ }^{17}$. Conforme o processo produtivo vai-se dando ao longo do tempo, o número de horas trabalhadas por unidade de produto vai caindo, pois na medida em que os trabalhadores vão adquirindo maior habilidade e destreza, aumentam o volume de produto produzido por hora trabalhada. A experiência acumulada leva a ganhos crescentes na produtividade. Notese que o acúmulo de conhecimento permite ganhos nas taxas de crescimento da economia. Dessa maneira, habilidade e conhecimento tornam-se insumos indispensáveis à função de produção.

A produção agregada pode, entretanto, ser elevada sem que ocorra aumento nos insumos de produção. Maior eficiência alocativa no uso dos insumos pode também

\footnotetext{
${ }^{16}$ Este artigo encontra-se bem explicado em Solow (1997).

${ }^{17}$ Estudo empírico bastante interessante sobre o assunto é o de Rapping ( 1965)
} 
aumentar a produtividade da economia. A capacidade administrativa associada ao arranjo institucional e organizacional pode alterar o total produzido a partir de mesma quantidade de insumos. Em outras palavras, dependendo do arranjo institucional uma dada economia pode operar dentro da fronteira de possibilidades de produção.

Exemplo bastante ilustrativo desse fenômeno é o caso da agricultura chinesa. Em 1978 o governo chinês instituiu relevante mudança na organização da produção agrícola. Antes de 1978 trabalhava-se em propriedades coletivas: 20 a 30 famílias produziam em bloco conjunto, com o governo determinando as quantidades e a área a ser cultivada por lavoura. As quantidades acima da cota máxima estabelecida deveriam ser entregues ao Estado (Stern, 1994). No sistema criado a partir de 1978, cada família arrendava um pedaço de terra do governo, pagando pela mesma uma cota fixa pré-determinada em produto. A produção obtida acima da cota poderia ser comercializada pelo arrendatário. O programa também contou com uma elevação em $20 \%$ nos preços pagos pelo produto, além de incentivos ao uso de insumos modernos (principalmente fertilizantes). A combinação de todas essas mudanças levou a um aumento da produção, entre 1978 e 1985, de 7,7\% ao ano (Stern, 1978). Lin (1992) calcula que $40 \%$ desse aumento podem ser atibuídos às reformas na organização da produção.

O mesmo pode acontecer caso a infra-estrutura da economia seja deficiente. Como aponta Stern (1991), é bastante difícil garantir a manutenção da produção quando o fornecimento de eletricidade e água é irregular, o sistema de telefonia e de correios é ruim, e o sistema de transporte lento e oneroso. Em tais situações, mesmo que a tecnologia seja a mais moderna possível, as restrições em infra-estrutura não permitem que a economia opere na fronteira de produção.

O marco institucional pode limitar o crescimento de um país de outra forma que não a acima descrita. Em países que possuem um sistema legal burocratizado, onde os direitos de propriedade sejam pouco claros, onde a corrupção não seja devidamente 
punida, o estímulo ao investimento produtivo também cai. Nessas condições, os recursos são desviados dos seus verdadeiros donos, reduzindo os retornos aos investimentos. Além disso, na medida em que a firma não recebe o equivalente a produtividade marginal dos fatores de produção, perde-se o incentivo a novas inversões. A queda nos investimentos diminuirá o ritmo da acumulação de capital, reduzindo a taxa de crescimento econômico.

O acúmulo de capital é o elemento mais estudado da teoria do crescimento econômico. Como aponta Furtado (1977), o problema fundamental do desenvolvimento econômico diz respeito ao processo de acumulação de capital e da sua distribuição entre os agentes econômicos. O acúmulo de capital permite que ocorra um aumento na produtividade global da economia, o que por sua vez leva a um aumento na poupança social, que induz a uma elevação na taxa de investimento, que desta forma garantirá um aumento no processo de acumulação. Esse mecanismo é o fio condutor do crescimento econômico. Estudar o que vem ocorrendo com o processo de acumulação de capital em uma economia, ou em um setor, permite dimensionar suas potencialidades de crescimento. Essa é, também, preocupação central do presente estudo.

À luz dos seis determinantes do crescimento sistematizados por Stern (1991), pode-se fazer um resumo das possíveis explicações sobre o bom desempenho relativo da agricultura brasileira a partir dos anos 80. Durante os anos 70 foram criadas diversas instituições de pesquisa agrícola que se espalharam por todo país (ver Alves e Contini, 1992) . Os resultados obtidos naqueles centros passaram a ser disseminados nas crescentes escolas de engenharia agronômica, engenharia florestal, medicina veterinária e zootecnia. Em 1969 estes cursos eram ministrados em 49 unidades que somavam 1.008 vagas. Em 1986 este número subiu para 7.203 vagas em 96 instituições (Alves e Contini, 1992). Em 1994 atingiu-se 12.142 vagas disponíveis em 177 instituições distintas (Araújo et alii, 1996). Um número crescente de técnicos ligados ao setor foi em boa parte aproveitado pelos centros de extensão criados pelo estado brasileiro a fim de divulgar as pesquisas e as modernas técnicas de cultivo. O aumento dos investimentos 
em pesquisa e desenvolvimento e na dotação de capital humano ligado a agricultura seria parte dos requisitos estruturais ao crescimento do setor (Mendonça de Barros, 1979).

Paralelamente aos investimentos em educação e pesquisa um volume expressivo de recursos era destinado a estimular os investimentos em capital físico. Como apontado na seção anterior, os volumes de compras de máquinas agrícolas, fertilizantes e defensivos aumentaram substancialmente durante os anos 70 e início dos 80 . Associada aos investimentos na agricultura encontrava-se a melhoria na infra-estrutura de transportes no país. Todo o conjunto viário construído em direção ao Centro-Oeste permitiu que uma agricultura moderna se desenvolvesse nesse novo pólo de crescimento. O processo de acumulação de capital foi, portanto, vigoroso naquele período.

Como sabido, os retornos ao investimento em pesquisa, principalmente na agricultura, são bastante lentos. É de se esperar uma defasagem entre a criação, dos centros de pesquisas e seus resultados em termos de inovações tecnológicas. O mesmo acontece com o processo de difusão das novas técnicas. Leva tempo até que os agentes tenham perfeito conhecimento do funcionamento da nova tecnologia. Os incrementos de produtividade advindos do uso das novas técnicas ("learning-by-doing") só aparecem com a maturidade. Assim, era de se esperar que os incrementos da produtividade não ocorressem de forma vigorosa na década de 70 . Os retornos aos investimentos realizados só surtiriam efeito na década seguinte. Em outras palavras, aquele período teria servido como base para o crescimento que se seguiria. Mesmo com a recessão por que passaria a economia brasileira nos anos 80 , alguns alicerces para o crescimento já haviam sido construídos.

Ocorre, contudo, que a despeito dos investimentos realizados, a forte intervenção estatal na agricultura brasileira teria induzido uma redução na eficiência econômica do setor. Como sintetizado nas seções anteriores, o caráter discricionário das políticas 
agrícolas acabou por elevar a variabilidade dos preços, da produtividade e da renda de parte significativa da produção (Homem de Mello, 1988), reduzindo as inversões nesse segmento. A política de modernização da agricultura brasileira, estimulada pelo Sistema Nacional de Crédito Rural, também teria contribuído para redução da eficiência alocativa. Como apontam Sanders e Ruttan (1978), a política de crédito rural subsidiado acabou por alterar o preço relativo dos fatores, beneficiando aquelas regiões onde a mão-de-obra era mais escassa. $\mathrm{Na}$ medida em que os custos dos insumos modernos eram reduzidos, havia um estímulo à substituição de trabalho por capital. Ao serem criadas condições "artificiais" no mercado de fatores, a eficiência alocativa seria reduzida (Pastore, 1979). A abundância do crédito rưral subsidiado criaria um ambiente de baixo estímulo ao aumento da eficiência técnica e econômica. Os volumes de crédito eram proporcionais a área de cada agricultor (Goldin e Rezende, 1993); assim, quanto maior a área, maior a capacidade de obtenção de crédito subsidiado.

Ora, conforme a capacidade de intervenção do setor público foi diminuindo nos anos 80 , as distorções no mercado de fatores foram também regredindo. A redução do subsídio implícito no crédito rural, a partir de 1986, não mais permitiria o uso de insumos modernos em quantidades superiores às de equilíbrio em um mercado competitivo. A retirada do Estado pressionaria o setor a um " processo de ajustamento com métodos de racionalização da produção" (Dias, op.cit.). A natureza competitiva da agricultura associada à retirada dos subsídios não mais permitiria a ineficiência produtiva.

Pode-se, então, sintetizar os argumentos que explicariam o bom desempenho relativo da agricultura brasileira nos anos 80 e 90 . O acúmulo de capital físico e humano, o aumento nos investimentos em pesquisa e extensão, a expansão e melhoria da infra-estrutura básica no país ocorridos ao longo dos anos 70, serviram de base para o crescimento que se seguiria. A progressiva redução na intervenção estatal no decorrer dos anos 80 associada ao aprendizado das modernas técnicas de produção, pressionaria 
os agentes a um aumento na eficiência técnica. O vetor de todas essas forças conduziria então a agricultura a um aumento da produtividade total dos fatores.

Parece possível, portanto, entender o desempenho da agricultura brasileira a partir de estudos empíricos que venham comprovar a importância relativa de cada um dos determinantes do crescimento. O presente estudo centra a análise no processo de acumulação de capital. Procurará concentrar esforços na mensuração dos investimentos em máquinas agrícolas no período de 1970 a 1996. O objetivo principal é o de entender o que ocorreu com o estoque de tratores no Brasil ao longo do período. Como foi determinado por Barros (1980), o fator que mais explicou o investimento em tratores no país nos anos 70 foi o crédito subsidiado. Com sua diminuição cabe dimensionar seus impactos sobre o processo de acumulação de capital. Além disso, na medida em que a evolução do estoque de tratores for construída, poder-se-á fazer alguma inferência quanto à importância do capital na explicação do crescimento do setor. Teria ocorrido uma deterioração significativa do estoque acumulado nos anos 70 e meados dos 80 ? Em caso afirmativo, cabe saber se o nível atual do estoque poderá comprometer o crescimento futuro do setor.

A pergunta levantada parece ser relevante. A partir dos dados de vendas internas de tratores de roda pode-se notar que, de fato, houve clara redução no volume de negócios. A tabela 5, a seguir, ilustra as vendas de tratores de roda no Brasil no período de 1970 a 1996. Note-se que em 1970 foram vendidos quase 14,6 mil unidades de tratores de roda. Em 1976 esse número atingiu quase 63 mil unidades quando, a partir de então, começou a decrescer. Em 1996, foram vendidas quase 10,3 mil unidades, número inferior ao de quase 26 anos atrás. 
Tabela 5 - Vendas Anuais e Médias Quinquenais de Vendas de Tratores de Rodas ao Mercado Interno, Brasil, 1970-1996.

\begin{tabular}{ccc}
\hline Ano & Tratores de Roda & Médias Quinquenais \\
\hline 1970 & 14.586 & \\
1971 & 21.947 & \\
1972 & 29.254 & \\
1973 & 38.918 & \\
1974 & 45.226 & \\
1975 & 57.101 & \\
1976 & 62.700 & \\
1977 & 47.815 & \\
1978 & 41.017 & \\
1979 & 48.963 & \\
1980 & 50.195 & \\
1981 & 27.949 & \\
1982 & 24.615 & \\
1983 & 22.546 & \\
1984 & 41.645 & \\
1985 & 40.736 & \\
1986 & 45.297 & \\
1987 & 38.815 & \\
1988 & 29.921 & \\
1989 & 26.310 & \\
1990 & 21.241 & \\
1991 & 13.495 & \\
1992 & 11.727 & \\
1993 & 21.396 & \\
1994 & 38.491 & \\
1995 & 17.584 & \\
1996 & 10.291 & \\
1997 & 15.731 & \\
\hline
\end{tabular}

Fonte : ANFAVEA

O próximo capítulo apresenta o modelo formal, utilizado por Barros (1980), que identifica quais as regras de decisão de investimento em um bem durável adotadas pela firma. O objetivo do capítulo é tornar explícito que a decisão de investimento é uma função direta de uma série de variáveis econômicas constantemente alteradas pelos 
ciclos econômicos. O ponto a ser feito é que no processo de construção do estoque de capital é fundamental que se capte a avaliação do mercado quanto ao valor atribuído aos serviços do capital. É frequente encontrar na literatura estudos que fazem uso de taxas contábeis para mensurar a depreciação do capital. Ao proceder dessa maneira, perde-se, de imediato, a informação mais preciosa a ser perseguida, qual seja, o valor atribuído pelo mercado ao seu estoque produtivo. O presente trabalho, como dito, procurará dimensionar o valor do estoque de tratores a partir de curvas de preços de tratores de segunda mão, captando, dessa maneira, a taxa de depreciação econômica do estoque. Este é o objetivo do quarto capítulo. 


\section{3 - O MODELO: TOMADA DE DECISÃO DA FIRMA}

Ponto que chama atenção quando se faz uma revisão dos estudos acerca da demanda de tratores é a diversidade de variáveis independentes usadas nos modelos. Em geral, os trabalhos empíricos não partem de um modelo teórico de decisão da firma; quase sempre são testadas diversas variáveis procurando-se aquelas que apresentam estatísticas favoráveis. Dos estudos analisados apenas o de Barros (1980) teve a preocupação em partir de um modelo teórico e, por essa razão, é sumarizado a seguir.

\section{O MODELO}

A principal preocupação do modelo proposto por Barros (1980) é o entendimento da tomada de decisão da firma frente ao uso dos insumos duráveis. $\mathrm{O}$ agente deverá decidir qual a intensidade e o tempo de duração do fluxo de serviços a serem obtidos com o bem durável. Quanto mais intenso for o uso do insumo, menor sua longevidade. Note-se que estas duas decisões estão intrinsicamente relacionadas. A única forma de extrair mais serviços do insumo e manter até certo ponto sua longevidade, é aumentar o dispêndio na manutenção do mesmo.

Segundo o modelo,'a firma tem dois objetivos específicos: maximizar tanto o lucro quanto o valor presente líquido do conjunto de seus insumos duráveis. O aumento no valor do estoque de capital dependerá das decisões de investimento líquido (portanto, do investimento bruto e da depreciação). Pressupõe-se, adicionalmente, que o agente tenha perfeito conhecimento do futuro, embora as decisões passadas não impliquem perfeito acerto. 
A firma opera em um mercado de concorrência perfeita produzindo um volume (Y) a partir do serviço $(\theta)$ de um insumo durável (D) e um insumo não-durável $\left(\mathrm{X}_{1}\right)$, estabelecendo a seguinte relação funcional:

(3.1) $\mathrm{Y}_{\mathrm{t}}=\mathrm{F}\left(\mathrm{X}_{1 \mathrm{t}}, \theta_{\mathrm{t}}\right)$

O serviço $(\theta)$ é originado a partir do estoque de insumos duráveis (D), dependendo, também, do uso de um insumo não-durável complementar $\left(X_{2}{ }^{\prime}\right)$, ou seja:

(3.2) $\theta_{t}=g\left(X_{2 t} / D_{t}\right)$

A vida útil do insumo (D) dependerá da intensidade de uso do equipamento e da qualidade da manutenção $\left(\mathrm{X}_{3}\right)$. Assim, a longevidade do insumo durável pode ser expressa da seguinte forma:

(3.3) $\mathrm{T}=\mathrm{h}\left(\theta_{1}, \theta_{2}, \ldots, \theta_{\mathrm{t}}, \ldots, \theta_{\mathrm{TH}}, \mathrm{X}_{31}, \mathrm{X}_{32}, \ldots ., \mathrm{X}_{3 \mathrm{t}}, \ldots, \mathrm{X}_{3 \mathrm{TH}}\right)$

onde $\mathrm{T}_{\mathrm{H}}$ é o horizonte temporal de planejamento da firma.

A função objetivo (G) da firma é composta pelo lucro corrente $(\pi)$ e pelo ganho no valor presente líquido (GVPL) dos insumos duráveis, ou seja:

(3.4) $\mathrm{G}_{\mathrm{t}}=\pi_{\mathrm{t}}+\mathrm{GVPL}_{\mathrm{t}}$ 
O lucro da firma será dado por:

$$
\pi_{t}=P_{t} Y_{t}-P_{1 t} X_{1 t}-P_{2 t} X_{2 t}-P_{3 t} X_{3 t}-\operatorname{CTU}\left(\theta_{t}\right)-C F_{t}
$$

onde,

$\mathrm{P}_{\mathrm{t}}=$ preço do produto

$\mathrm{P}_{\mathrm{it}}=$ preço do i-ésimo insumo com $\mathrm{i}=1,2,3$

CTU $\left(\theta_{t}\right)=$ custo total do uso do insumo durável

$\mathrm{CF}_{\mathrm{t}}=$ custo fixo do insumo durável

O custo total de uso do insumo durável representa o custo de oportunidade do mesmo.

Caberá a firma, em cada momento, decidir pela aquisição ou venda do insumo durável. Essa decisão, por sua vez, será função do valor atribuído pela firma aos serviços advindos do insumo durável. Seja então o valor de uso (VU) do insumo durável definido por:

$$
\mathrm{VU}\left(\theta^{*}, \mathrm{~T}^{*}\right)=\sum_{\mathrm{t}=1}^{\mathrm{T}^{*}}\left[\int_{0}^{\theta_{\mathrm{t}}^{*}} \mathrm{VMP} \theta_{\mathrm{t}} \mathrm{d} \theta_{\mathrm{t}^{-}} \int_{0}^{\theta_{\mathrm{t}}^{*}} \mathrm{CMF} \theta_{\mathrm{t}} \mathrm{dt}-\mathrm{CF} F_{\mathrm{t}}\right] \frac{1}{(1+\mathrm{r})^{\mathrm{t}}}+\frac{\mathrm{P}_{\mathrm{V}}\left(\mathrm{T}^{*}\right)}{(1+\mathrm{r})^{\mathrm{T}^{*}}}
$$

onde,

$\mathrm{VMP}_{\mathrm{t}}=$ valor do produto marginal do serviço do insumo durável

$\mathrm{CMF} \theta_{\mathrm{t}}=$ custo marginal do serviço do insumo durável

$P_{v}=$ preço de venda do insumo durável

$\mathrm{Na}$ expressão (3.6), o asterisco representa o ponto ótimo de cada item especificado. Note-se que o termo entre colchetes representa o valor da produção acumulado no período útil do insumo, deduzido dos custos variáveis e fixos acumulados no mesmo intervalo de tempo. 
A partir da expressão (3.4) é possível estabelecer a regra de decisão quanto a aquisição de uma unidade do insumo durável. Se o valor de uso deduzido do preço de compra $\left(\mathrm{P}_{\mathrm{c}}\right)$ for positivo, haverá um ganho no valor presente líquido da firma (GVPL) e, portanto, compensará a aquisição daquela unidade. Ou seja,

(3.7) $\mathrm{GVPL}_{\mathrm{t}}=\mathrm{VU}\left(\theta^{*}, \mathrm{~T}^{*}\right)-\mathrm{P}_{\mathrm{c}}$

Para ser compensadora a compra de novas unidades, a seguinte regra deverá ser seguida:

(3.7') $\mathrm{GVPL}_{\mathrm{t}}=\Delta \mathrm{VU}\left(\theta^{*}, \mathrm{~T}^{*}\right)-\mathrm{P}_{\mathrm{c}}>0$

onde,

$\Delta \mathrm{GVPL}_{\mathrm{t}}=\Delta \mathrm{VU}\left(\theta^{*}, \mathrm{~T}^{*}\right)=$ variação no valor de uso do estoque

Analogamente, a decisão de venda da firma ocorrerá se a variação no valor de uso do estoque decorrente da venda de uma unidade, deduzido o preço de venda da mesma, gerar um saldo negativo:

(3.7'’) $\mathrm{GVPL}_{\mathrm{t}}=\Delta \mathrm{VU}\left(\theta^{*}, \mathrm{~T}^{*}\right)-\mathrm{P}_{\mathrm{v}}<0$

Se a variação no valor de uso da unidade em análise for menor do que o preço de compra e maior do que o preço de venda, não haverá alteração no tamanho do estoque: 
(3.8) $\mathrm{P}_{\mathrm{v}}<\Delta \mathrm{VU}\left(\theta^{*}, \mathrm{~T}^{*}\right)<\mathrm{P}_{\mathrm{c}}$

Partindo-se, então, da função objetivo (3.4) e das restrições representadas pelas equações (3.2) e (3.3), pode-se construir a seguinte expressão de Lagrange a ser maximizada:

$$
\begin{aligned}
L= & P_{t} F\left(X_{1 t}, \theta_{t}\right)-P_{1 t} X_{1 t}-P_{2 t} X_{2 t}-P_{3 t} X_{3 t}-C T U_{t}\left(\theta_{t}\right)-C F_{t}- \\
& -\phi_{t}\left(\theta_{t}-g\left(X_{2 t} / D_{t}\right)\right)-\gamma_{t}\left(T-h\left(\theta_{1}, \ldots, \theta_{2}, \ldots, \theta_{t}, \ldots, \theta_{T H}, X_{31}, X_{32}\right.\right. \\
& \left.\left.\ldots ., X_{3 t}, \ldots, X_{3 T H}\right)\right)
\end{aligned}
$$

$\mathrm{Da}$ equação (3.9) extraem-se as condições de primeira ordem para a maximização da função, quais sejam:

(3.10) $\frac{\partial \mathrm{L}}{\partial \mathrm{X}_{\mathrm{tt}}}=\mathrm{P}_{\mathrm{t}} \frac{\partial \mathrm{F}}{\partial \mathrm{X}_{\mathrm{tt}}}-\mathrm{P}_{1 \mathrm{t}}=0$

(3.11) $\frac{\partial \mathrm{L}}{\partial \mathrm{X}_{2 \mathrm{t}}}=-\mathrm{P}_{2 \mathrm{t}}+\phi_{\mathrm{t}} \frac{\partial \mathrm{g}}{\partial \mathrm{X}_{2 \mathrm{t}}}=0$

(3.12) $\frac{\partial L}{\partial X_{3 t}}=-P_{3 t}+\gamma_{t} \frac{\partial h}{\partial X_{3 t}}=0$

$$
\frac{\partial \mathrm{L}}{\partial \theta_{\mathrm{t}}}=\mathrm{P}_{\mathrm{t}} \frac{\partial \mathrm{F}}{\partial \theta_{\mathrm{t}}}-\frac{\partial \mathrm{CTU}}{\partial \theta_{\mathrm{t}}}-\phi_{\mathrm{t}}+\gamma_{\mathrm{t}} \frac{\partial \mathrm{h}}{\partial \theta_{\mathrm{t}}}=0
$$

(3.14) $\frac{\partial \mathrm{L}}{\partial \phi_{\mathrm{t}}}=\theta_{\mathrm{t}}-\mathrm{g}\left(\mathrm{X}_{2 \mathrm{t}} / \mathrm{D}_{\mathrm{t}}\right)=0$

(3.15) $\frac{\partial \mathrm{L}}{\partial \gamma_{\mathrm{t}}}=\mathrm{T}-\mathrm{h}\left(\theta_{1}, \theta_{2}, \ldots, \theta_{\mathrm{t}}, \ldots, \theta_{\mathrm{T}_{\mathrm{H}}}, \mathrm{X}_{31}, \mathrm{X}_{32}, \ldots, \mathrm{X}_{3 \mathrm{t}}, \ldots, \mathrm{X}_{3 \mathrm{~T}_{\mathrm{H}}}\right)=0$ 
Dois pontos merecem ser levantados antes da interpretação das equações (3.10) a (3.15). Em primeiro lugar, vale notar que as equações (3.10) a (3.15) referem-se a um período de tempo (t). Assim, para cada um dos períodos haverá um conjunto de equações semelhantes àquelas, dentro do universo temporal $\mathrm{T}_{\mathrm{H}}$. $\mathrm{O}$ segundo ponto a ser comentado é que as condições de segunda ordem não serão aqui discutidas. Assumese, de antemão, que as funções (3.1), (3.2) e (3.3) apresentam formas bem comportadas que atendam tais condições.

A condição (3.10) indica que o insumo não durável $X_{1}$ deve ser empregado até que o valor do seu produto marginal seja igual ao seu preço.

A condição (3.11) implica que $\phi$ seja dado por,

$$
\text { (3.11') } \phi_{t}=\frac{P_{2 t}}{\frac{\partial g}{\partial X_{2 t}}}
$$

Ou seja, o multiplicador mede o aumento no custo da firma advindo do uso adicional do inśumo não durável (complementar), necessário para gerar serviços adicionais do insumo durável.

Analogamente, o multiplicador $\gamma$ representa o aumento no custo resultante de alteração no tempo de uso do insumo durável: 


$$
\text { (3.12') } \gamma_{\mathrm{t}}=\frac{\mathrm{P}_{3 \mathrm{t}}}{\partial_{\mathrm{h}_{3 \mathrm{t}}}}
$$

Para melhor entender a condição (3.13) vale a pena substituir $\gamma_{t}$ em (3.13) pela expressão (3.12'). Rearranjando os termos, chega-se a :

$$
\text { (3.13') } \phi_{\mathrm{t}}=\mathrm{P}_{\mathrm{t}} \frac{\partial \mathrm{F}}{\partial \theta_{\mathrm{t}}}+\left[\frac{\mathrm{P}_{3 \mathrm{t}}}{\frac{\partial \mathrm{h}}{\partial \mathrm{X}_{3 \mathrm{t}}}}\right] \frac{\partial \mathrm{h}}{\partial \theta_{\mathrm{t}}}-\frac{\partial \mathrm{CTU}}{\partial \theta_{\mathrm{t}}}
$$

A expressão acima implica que se deve empregar $X_{2}$ até o ponto em que o custo marginal da geração de serviços é igual ao valor do produto marginal desses serviços (primeira expressão do lado direito), deduzidos os custos de oportunidade do serviço $\left(\partial \operatorname{CTU}_{t} / \partial \theta_{t}\right)$ e o custo marginal de se usar mais intensamente o insumo durável (o que requer maior gasto com manutenção). Note-se, portanto, que para a firma individual não interessa apenas o custo de oportunidade do serviço advindo de insumo; há que se considerar também que a atividade da firma no ano corrente compete com a atividade nos demais anos: Existe, portanto, um problema intertemporal de alocação dos serviços do insumo durável.

Vale lembrar que, além do problema de otimização da intensidade no uso do insumo durável, a firma leva em consideração os ganhos decorrentes das alterações no portfólio de insumos duráveis por ela possuídos. Na aquisição de um novo trator a firma leva em consideração o aumento no lucro corrente, bem como o ganho no valor líquido dos ativos se a nova unidade representar, para a mesma, um valor superior ao de aquisição. 
Como visto na condição (3.6), a tomada de decisão da firma quanto à aquisição de um equipamento durável adicional, depende do valor presente dos serviços extraídos otimamente durante a duração também ótima do insumo, adicionado o preço de venda do mesmo. Até aqui, viu-se como a firma otimiza os serviços extraídos; cabe, ainda, estabelecer qual a duração ótima $\left(\mathrm{T}^{*}\right)$ da vida do insumo durável. A questão é, então, maximizar a seguinte função:

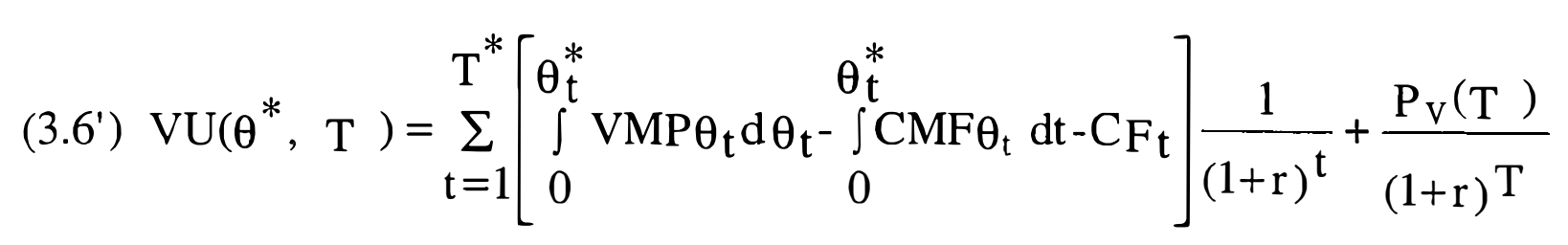

A expressão (3.6') pode ser simplificada por

$$
\left(3.6^{\prime \prime}\right) \operatorname{VU}\left(\theta^{*}, \mathrm{~T}\right)=\operatorname{VPLS}(\mathrm{T})+\mathrm{VP}_{\mathrm{v}}(\mathrm{T})
$$

onde VPLS (T) representa o primeiro termo em (3.6') (valor presente líquido dos serviços) e $\mathrm{VP}_{\mathrm{v}}$ é o valor presente do preço de venda.

Como $\mathrm{T}$ é medido discretamente no modelo, não é possível chegar ao ótimo tomando-se as derivadas. Pode-se, contudo, estabelecer a regra para que $\mathrm{T}$ seja otimizado $\left(\mathrm{T}^{*}\right)$. Em cada período $\mathrm{T}$, analisa-se a relação entre VPLS e $\mathrm{VP}_{\mathrm{v}}$; quando o acréscimo em VPLS compensar exatamente o decréscimo em $V_{\mathrm{v}}$, estar-se-á em T*. Quando o incremento em VPLS for menor que o decréscimo em $\mathrm{VP}_{\mathrm{v}}$, o insumo deverá ser vendido. Para calcular se é compensadora a compra de novas unidades a firma deverá sempre simular o aumento em VU $\left(\theta^{*}, \mathrm{~T}^{*}\right)$ advindo da nova aquisição. Se esse 
incremento for superior ao preço de aquisição, a firma deverá comprar essa unidade adicional. Note-se, portanto, que para cada unidade de insumo durável adicional há que se recalcular o ponto ótimo.

A partir das condições (3.10) a (3.15) e dos critérios para investimento e desinvestimento, nota-se que o estoque ótimo depende, basicamente, das seguintes variáveis:

i) preços de insumos não-duráveis usados na produção;

ii) preços dos insumos usados na geração de serviços dos tratores;

iii) preços dos insumos utilizados na manutenção dos tratores;

iv) preço do produto da firma;

v) preços de compra e venda dos insumos duráveis; e,

vi) taxa de juros.

Alterações nessas variáveis determinarão a longevidade de uso do equipamento. Se, por exemplo, os gastos com manutenção do insumo durável aumentarem, haverá uma tendência à redução da vida ótima do equipamento. Aumento no custo de manutenção induz a uma aceleração da depreciação de equipamento. Alterações nos preços de compra e venda dos tratores com relação aos preços dos produtos promoverão ajustamentos no nível do estoque desejado. Aumento na taxa de juros reduz o valor presente dos tratores, o que acaba por desestimular o investimento.

Dessa maneira, pode-se perceber que se for possível captar algum sinal do mercado que indique o padrão de evolução do valor do bem durável estudado, será possível ter idéia de como as variáveis anteriormente elencadas vêm afetando a tomada de decisão da firma. Em especial, ao determinar a depreciação econômica de tratores com base em dados amostrados, será possível estabelecer a evolução do valor do estoque de capital na agricultura nos últimos 25 anos. 


\section{4 - INVESTIMENTO ACUMULADO: O ESTOQUE DE TRATORES}

"The capital time series is the one that will drive a purist mad."

Robert Solow, 1957

\section{1 - INTRODUÇÃO}

Um dos problemas de mais difícil solução nos estudos de produtividade refere-se a construção da série de capital (Solow, 1963). Por se tratar de um insumo que prestará serviços ao longo de um período relativamente longo de tempo, há uma série de dificuldades de mensuração. Em primeiro lugar, existe a cada momento no tempo uma grande diversidade na qualidade dos bens duráveis. Além disso, conforme passa o tempo, essas diferenças qualitativas vão se tornando progressivamente mais acentuadas, indicando que inferências de prazo mais longo requerem certa cautela. Um segundo aspecto importante, levantado por Harberger (1960), é que os dados sobre preços tendem também a apresentar problemas no que se refere aos bens duráveis. Esse aspecto é a contrapartida quantitativa do problema qualitativo acima referido: o mercado de bens duráveis cobre uma faixa enorme de diferentes tipos de bens, ao passo que o mercado de soja, por exemplo, é certamente muito mais homogêneo.

A demanda por um bem de capital apresenta, por sua própria natureza, uma estratificação bem acentuada. Em cada momento no tempo existe uma demanda por tratores e uma demanda por novos tratores. Estas demandas são claramente correlacionadas. O estoque de tratores não pode ser aumentado sem que novas unidades sejam adquiridas e, portanto, novas máquinas são necessárias para manter um dado 
estoque, face à depreciação do mesmo. Ocorre, contudo, que uma correlação precisa entre essas variáveis não é muito clara. Como aponta Harberger (1960), o desejo de se aumentar o estoque de tratores em $10 \%$ pode ser acomodado por um aumento no número de tratores em um único ano, ou essa demanda pode ser ajustada em 10 anos, com um aumento de $1 \%$ ao ano.

Dessa maneira, pode-se perceber que existem diferentes padrões de demanda por novos equipamentos consistentes com uma demanda por tratores. Tudo dependerá da velocidade de ajustamento do estoque. O ponto a ser ressaltado é que a associação entre o estoque acumulado e as novas aquisições alteram-se conforme as condições econômicas vão mudando, como visto no capítulo anterior. O tamanho e o valor do estoque relativamente aos ciclos econômicos fazem com que os agentes estejam permanentemente revendo suas decisões de investimento.

Não é possível fugir das dificuldades de mensuração do estoque existente focalizando apenas a demanda por fluxos, uma vez que há forte correlação entre o estoque existente e a velocidade das novas aquisições. Para uma dada demanda de serviços advindos de um bem durável, novas aquisições serão tanto maiores quanto menores forem os serviços obtidos pelo estoque existente naquele momento.

Outro problema relacionado aos estoques refere-se ao fato de não ser muito fácil medir os serviços advindos de um dado estoque. Se, por exemplo, tratores de idades distintas fornecerem idênticos serviços, a melhor medida para o estoque será o número total de tratores. Se, por outro lado, o serviço fornecido por um trator for proporcional ao seu valor, a melhor medida do estoque será dada pelo seu valor total. Uma forma de identificar qual a melhor representação dos estoques é através da curva de depreciação do bem. Se o trator tende a depreciar anualmente por um montante constante ao ano, isso indicaria que o volume de serviços extraídos do bem tende a ser mais ou menos o mesmo para todas as idades e, portanto, a medida do estoque expressa em números seria preferível. Se o bem durável tende a depreciar por uma porcentagem constante do seu valor a cada ano, a medida do valor agregado do estoque seria preferível como indicação do volume de serviços gerados. 
Note-se que o padrão da curva de depreciação passa a ser elemento chave na determinação do estoque de capital. A velocidade de redução do preço do equipamento usado responde a avaliação do mercado quanto as oscilações dos ciclos de negócio, bem como dão dimensão à redução da vida útil e dos serviços do bem. Portanto, é da curva de depreciação que o estudo empírico deve partir.

\section{2 - Depreciação}

Segundo Jorgenson (1996), a depreciação de um bem durável é representada pela queda no preço do mesmo, refletindo a redução corrente e o valor presente das reduções futuras da eficiência do equipamento. A queda no preço do bem reflete, na realidade, o comportamento de 3 componentes de difícil separação: i) deterioração; ii) obsolescência e, iii) exaustão (Griliches, 1963a). A deterioração reflete a menor produtividade da vida útịl remanescente. Obsolescência indica as reduções nos preços dos bens decorrentes do surgimento de modelos mais modernos. A exaustão refere-se a redução na vida útil futura do bem.

O problema empírico relevante diz respeito ao estabelecimento da relação entre queda do preço e perda de eficiência produtiva do equipamento. Como aponta Griliches (1960a), existem várias possibilidades para o formato da curva de redução na eficiência do equipamento. Em um limite extremo, pode não haver redução alguma na eficiência produtiva do trator até o dia em que sua vida útil acabe. Em outro extremo, poder-se-ia imaginar que a redução na eficiência do equipamento ocorreria a uma taxa declinante constante, distribuída de forma equânime ao longo da vida útil do equipamento. Dentro desses dois limites existiria um espectro relativamente amplo de possibilidades. Griliches (1963a) apresenta uma série de curvas de redução na eficiência dos equipamentos. O autor chama atenção, da mesma forma que Jorgenson (1996) e Feldstein e Foot (1971), para o número reduzido de estudos estabelecendo uma correlação entre idade e perda de eficiência produtiva. 
A relação entre o preço do bem de capital e a quantidade de serviços por ele prestado é especialmente importante nos estudos sobre produtividade, uma vez que o que se quer medir é a quantidade de serviço físico extraída do estoque produtivo. $\mathrm{O}$ problema é ser possível que o preço do trator usado não reflita perfeitamente a quantidade de serviços por ele realizado. Ocorre, como aponta Griliches (1963b), que pode haver redução do valor do equipamento por obsolescência, ou seja, por que surgiram máquinas tecnologicamente mais avançadas. Ora, a existência de máquinas mais modernas não altera o volume de serviços físicos prestados pelo equipamento antigo (Solow, 1963). Enquanto eles forem rentáveis, as empresas seguirão usando seus bens de capital, mantendo assim o potencial produtivo de suas firmas ${ }^{18}$.

Para resolver essa questão, passa a ser interessante associar os estudos de perda de capacidade mecânica dos equipamentos aos estudos de depreciação econômica. Jorgenson (1996) faz uma revisão sobre o assunto, concluindo que os diferentes estudos empíricos referentes tanto às necessidades de reposição dos equipamentos em decorrência da perda de eficiência produtiva, quanto das curvas de preço do mercado de bens duráveis de segunda mão, indicam um comportamento bastante semelhante.

Em geral, o formato das curvas de depreciação encontradas nos diferentes trabalhos apontam para um comportamento geométrico declinante das mesmas. Estudando o mercado de carros usados, Wykoff (1970) e Cramer (1958) encontram que o formato geométrico representou bem o declínio nos preços com relação à idade. O já referido estudo de Griliches (1960) chega a mesma conclusão. Berndt (1991), citando Hulten e Wykoff (página 231), comenta que os autores são contundentes quanto à afirmação de que a representação linear da depreciação não é adequada, sugerindo

\footnotetext{
18 Vale a pena citar o trecho extraído de Solow (1963): "Como mencionei anteriormente, plantas e equipamentos obsoletos não precisam necessariamente desaparecer; podem continuar em uso enquanto renderem uma quase-renda qualquer. Se a substituição entre os insumos variáveis e o capital for relativamente fácil, então o capital antigo não será expulso da produção até o ponto de sua completa exaustão. Se, entretanto, houver substituição limitada entre os fatores, um eventual aumento dos salários e de outros custos tornará o capital obsoleto completamente anti-econômico, forçando assim o fim de suas operações” (página 58).
} 
claramente que o formato geométrico declinante e regular (hipérbole) é o que melhor se ajusta à série.

Outros estudos sobre o padrão de depreciação dos preços dos tratores usados corroboram os trabalhos acima citados. Mc Neill (1979), Reid e Bradford (1983), Perry et al (1990) e Cross e Perry (1995) encontram formatos geométricos declinantes das curvas de depreciação. A exceção encontrada na literatura foi o estudo de Penson et alii (1977). Trabalhando com dados de depreciação da capacidade produtiva, com base em informações da engenharia mecânica, os autores encontram um formato côncavo da curva de depreciação. Alguns dos autores fazem, ainda, um conjunto de comparações entre as curvas de depreciação de tratores de diferentes marcas e tamanhos. Cross e Perry (1995) estudam o efeito da marca sobre o padrão da depreciação encontrando curvas com mesmo formato mas com níveis distintos. Perry et al. (1990) concluem que a depreciação varia com o tamanho do equipamento: tratores maiores perdem valor mais rapidamente do que os menores. Os autores creditam esse comportamento ao fato de os tratores mais pesados serem submetidos a serviços mais intensos, o que acaba por acelerar o seu desgaste.

O uso da forma geométrica na redução dos preços dos bens duráveis usados parece ser quase consensual entre os estudos resenhados. Existe certa controvérsia, entretanto, quanto a hipótese da depreciação ser constante ao longo do tempo. Griliches (1960a) e Wykoff (1970) já haviam percebido que a taxa de depreciação teria registrado alterações nos diferentes momentos amostrados. Mais recentemente, Nelson e Caputo (1997), estudando a depreciação no mercado de aviões mono e bi-motores de segunda mão nos EUA, perceberam que a taxa de depreciação mostrou-se variável conforme as condições econômicas. Esses autores julgam ser um tanto forte a hipótese de taxas geométricas de depreciação constantes ao longo do tempo, independentemente das condições econômicas. Em seu trabalho utilizam como variáveis econômicas relevantes o preço do avião e os custos de manutenção, além de variáveis relacionadas às especificações do equipamento (tamanho, velocidade, capacidade de carga, etc.). 
Estudaram um período (1970-1991) em que houve uma mudança na forma de computar os passivos das empresas ligadas ao setor. ${ }^{19}$ Essa mudança acarretou um aumento nos passivos da ordem de 775\%, o que contribuiu para elevar os preços dos equipamentos novos e usados. Esse aumento nos preços teria diminuído as taxas anuais de depreciação em $18,22 \%$ entre 1971 e 1975 e em $22,34 \%$ entre 1980 e 1991 . Os autores concluem que essas alterações nas taxas de depreciação favorecem a idéia de endogenização da depreciação nos estudos referentes ao capital. Vale ressaltar, entretanto, que o expressivo aumento observado no trabalho acima citado não é uma situação normal de mercado. Dificilmente têm-se aumentos de passivo da ordem de $800 \%$ em um curto período de tempo. Vale notar que caso a série se mantenha constante no novo nível de preços, é possível que a taxa de depreciação não sofra alterações significativas.

Na realidade essa questão já havia sido levantada há muito tempo por Feldtein e Foot (1971). Esses autores afirmaram que no curto prazo as taxas de depreciação sofriam oscilações decorrentes das alterações nos gastos com manutenção e nos impostos. Entretanto, no longo prazo a taxa de depreciação é estável, podendo-se trabalhar com um valor fixo constante. Hulten et al., citados por Nelson e Caputo (1997), concluem que o uso de uma taxa constante de depreciação fornece boa aproximação da realidade, além de apresentar a vantagem adicional de facilitar bastante a construção de séries de estoque. Trabalhar com mudanças constantes na depreciação dificulta, em larga medida, o estudo empírico. Berndt (1991) chama atenção, também, para importância da utilização de uma forma simples de depreciação para construção de séries de capital. Jorgenson (1996) comenta que existem poucos bens duráveis cujos mercados de segunda mão possuam séries de preços suficientemente longas. Esse fato restringe as chances de melhorar as estimativas de depreciação; afirma também que assumir, no longo prazo, uma taxa de depreciação constante pode ser uma aproximação razoável.

\footnotetext{
${ }^{19}$ No original o novo sistema foi nomeado por "strict liability standard".
} 
No Brasil parece não existir nenhum estudo sobre investimento em tratores que tenha utilizado série de preços de máquinas de segunda mão. Barros (1980) não fez uso desse instrumental por ausência de informação, calculando a taxa de depreciação através da interpolação de dados dos Censos Agropecuários. A taxa assim estimada foi de 1,5\% a.a. no período de 1961 a 1979. Essa taxa é bastante inferior àquelas encontradas em Griliches (1963): as taxas de depreciação oscilaram entre 18,5\% e $11 \%$ nos EUA, dependendo da fonte de dados utilizada.

Barros (1980) chama atenção, contudo, para a importância da mensuração dos estoques em termos de valor. $\mathrm{O}$ autor afirma que a ausência de dados sobre o padrão da depreciação não permite medir qual é efetivamente a depreciação existente no estoque agregado. Na medida em que o Censo possibilita saber apenas qual o número de tratores existentes e sua respectiva potência, não há como saber qual a idade da frota. Pode-se calcular, apenas, quantos tratores saíram da produção no intervalo de dois censos.

O mesmo problema foi encontrado por Rocha (1986). Assim como Barros (1980), a autora utiliza os Censos Agropecuários e as vendas de tratores ao mercado interno para determinar a taxa de depreciação da frota brasileira entre 1969 e 1983. Rocha conclui que a vida útil do trator deveria ser superior a 15 anos para que houvesse compatibilidade entre as séries estudadas ${ }^{20}$.

A ausência de uma medida do valor de um dado estoque de capital merece especial atenção. Vale notar que é perfeitamente possível que um estoque aumente em número mas caia em valor agregado. Se as novas adições durante um período longo de tempo forem pequenas, o estoque acumulado pode até aumentar em número, mas, certamente, a frota estará envelhecendo e, portanto, apresentando um montante total de serviços menor (representado quantitativamente pelo valor do estoque).

\footnotetext{
${ }^{20}$ A autora chega a uma conclusão curiosa em seu trabalho. Baseando-se em estudos técnicos da sobrevivência de tratores agrícolas, afirma que é quase impossível que um trator tenha vida útil superior a 13 anos. Dessa maneira conclui que os dados censitários devem estar superestimados.
} 
Ora, esse fenômeno parece ser fundamental para analisar a formação de capital na agricultura brasileira nos anos 70 e 80 . Com os altos investimentos realizados na década de 70 até meados dos anos 80 , o número de tratores vendidos aumentou consideravelmente. A partir de então, as vendas ao mercado interno caíram sistematicamente. Se medido em termos numéricos, é perfeitamente possível que o estoque de tratores tenha aumentado consistentemente até 1996. Se expresso em valor, entretanto, é provável que o estoque esteja caindo à medida que a frota for envelhecendo. Pode-se notar, portanto, quão relevante é a determinação empírica da depreciação de um bem de capital.

Griliches (1963a) já havia destacado a importância do uso combinado das medidas de estoque (em valor e número) na avaliação do fluxo de investimento em tratores:

“... quando o investimento em tratores for alto durante o passado recente, o conceito de valor (do estoque) será alto relativamente ao conceito quantitativo (número) $e$, portanto, contribuirá positivamente para a previsão do investimento no próximo ano. Quando o investimento for abaixo da média por algum tempo, o conceito de quantidade será relativamente maior do que o conceito de valor, contribuindo negativamente para a previsão do investimento no próximo ano...".

(página 131)

Essa diferença aparentemente pequena na medida do estoque pode levar a alterações significativas na medida empírica da produtividade do capital. Imagine-se uma situação semelhante a descrita acima em que o estoque de capital esteja aumentando em número mas caindo em valor. Se a produtividade do capital for computada através de um índice do estoque medido em número, ela será certamente 
menor do que o resultado obtido medindo-se o estoque em valor. Observa-se assim que esse é um sério problema para quem estuda os fatores de crescimento da agricultura.

O presente trabalho procura representar o estoque de tratores no Brasil em número, em potência e em valor. Pretende-se determinar, empiricamente, a curva de depreciação para, a partir dela, construir as séries de estoque. Esse é o objetivo da próxima seção.

\section{3 - Medida da depreciação e do estoque de tratores no Brasil}

\subsection{1 - A base de dados}

Dos artigos resenhados anteriormente sobre o estoque de capital na agricultura brasileira não foi encontrado nenhum trabalho que procurasse determinar a depreciação do estoque com base em séries de preços de máquinas de segunda mão. Tanto os estudos de demanda de tratores (Barros, 1980 e Rocha, 1986), quanto os de produtividade (Gasques e Conceição, 1998 e Bonelli e Pessoa, 1998) fizeram uso de métodos indiretos para obtenção da série de estoque de capital. Os métodos utilizados são, em geral, de dois tipos: i) aqueles baseados na associação dos dados do Censo Agropecuário com a série de consumo aparente anual de tratores; e, ii) aqueles baseados na hipótese de depreciação constante do estoque de tratores (em geral, equivalente à perda de $10 \%$ do valor de um trator novo ao ano). A segunda formulação pressupõe que o trator tenha vida útil equivalente a 10 anos.

Pelas razões descritas na seção anterior pode-se perceber que nenhuma das duas soluções representa bem o que ocorreu com o estoque de máquinas na agricultura brasileira. No primeiro caso, embora os dados do Censo Agropecuário representem resultados bastante sólidos uma vez que as informações são levantadas nas propriedades rurais do país, os resultados não permitem nenhuma inferência quanto ao 
valor do estoque produtivo uma vez que é impossível estabelecer a distribuição etária da frota. A segunda forma de cômputo do estoque é seguramente menos satisfatória. Ao admitir uma vida útil fixa do trator (10 anos) não se leva em consideração as oscilações existentes na vida útil ótima do equipamento em decorrência das mudanças nas variáveis econômicas. Essa hipótese de depreciação guarda pouco respaldo empírico e, como será visto, produz fortes divergências com relação ao estoque levantado pelo Censo Agropecuário.

A idéia central a ser aqui desenvolvida consiste em combinar o uso de três fontes de dados básicos, quais sejam, o Censo Agropecuário, as séries de vendas anuais de tratores ao mercado interno e as séries de preços de tratores usados divulgadas pelo jornal "O Estado de São Paulo"21.

Foram utilizados os dados dos Censos de 1970, 1975, 1980, 1985 e 1995-96. No caso do último Censo, foram coletadas informações de cada um dos censos estaduais, uma vez que o censo nacional não havia sido divulgado quando do término do estudo. A tabela com a quantidade de tratores por estado da federação encontra-se no Apêndice A.

No caso da série de vendas de tratores no mercado interno, a fonte básica de informação advém do Anuário Estatístico da ANFAVEA (1998). Essa base de dados fornece as vendąs de tratores de roda em quatro classes de potência: i) tratores com até 49 cavalos (c.v.); ii) tratores de 50 a 99 c.v.; iii) tratores de 100 a 199 c.v.; e, iv) tratores com mais de 200 c.v.. Graças a essa divisão foi possível estimar o estoque de tratores medido em potência. As séries da ANFAVEA não consideram os tratores importados e, portanto, foram necessárias outras fontes para obter o consumo aparente de tratores de roda. Até o ano de 1977, as estatísticas foram levantadas do trabalho de Barros (1980), que fez uso de dados apresentados em estudo do Instituto de Economia Agrícola da

\footnotetext{
${ }^{21}$ A Folha de São Paulo divulgou durante o período de janeiro de 1989 e abril de 1991 uma série de preços de tratores usados de diferentes marcas e potências. Entretanto, esses dados contemplavam apenas os tratores com até 8 anos de idade, o que não permite grande precisão nas estimativas da depreciação. Como os dados do jornal O Estado de São Paulo fornecem informações de preços de tratores com até 21 anos de uso, optou-se por essa fonte.
} 
Secretaria de Agricultura do Estado de São Paulo (IEA). De 1978 até 1997, as informações foram levantadas junto a CACEX. A série obtida nessa última fonte continha apenas a quantidade e o valor de importação de tratores de roda, não apresentando a potência média de cada equipamento. Para obter uma estimativa da potência comparou-se o preço médio do trator importado com um trator vendido no mercado nacional com preço equivalente e com a potência conhecida. As séries de vendas de tratores de roda ao mercado interno e de importação encontram-se no Apêndice A.

Durante o período de abril de 1997 e setembro de 1998, o jornal "O Estado de São Paulo" divulgou, mensalmente (em alguns períodos quinzenalmente), um suplemento especializado em máquinas e implementos agrícolas. Esses suplementos apresentavam preços de tratores novos e usados de diferentes marcas e potência, levantados junto a revendedores de tratores do interior do Estado de São Paulo. As séries compiladas dão conta de preços de tratores com idade de zero a 21 anos. Entretanto, poucos modelos de tratores apresentavam séries completas, uma vez que muitos deles não foram produzidos por período tão longo ou não foram comercializados no período de coleta da informação. Na realidade apenas dois modelos da marca Massey Ferguson (MF) mostraram consistentemente preços para cada idade considerada, embora em alguns meses até mesmo essas duas séries tenham sido incompletas. Selecionaram-se; então, apenas as séries completas de preços dos tratores MF 275 e MF 290, apresentadas no Apêndice A.

\subsection{2 - A Análise dos dados de depreciação}

Quando se iniciou o estudo com as séries de preços de tratores duas perguntas básicas requeriam resposta: i) existe variação significativa na taxa de depreciação em momentos distintos do tempo? e, ii) há diferença expressiva na taxa de depreciação de tratores de diferentes faixas de potência? Essas duas questões eram centrais uma vez 
que a qualidade da subsequente construção do estoque de tratores dependeria, em última instância, de quão bem o padrão de depreciação adotado fosse fiel aos mercados dos diferentes tipos de tratores de roda.

A inspeção dos dados parece indicar que o padrão de depreciação dos dois modelos considerados era bastante semelhante. A figura 3 apresenta a média das séries de preços dos tratores MF 275 e MF 290 com até 21 anos de uso. Os dados foram normalizados com base no preço do trator novo, de tal forma que os preços refletem a porcentagem com relação ao trator com zero hora de uso. Pode-se notar que existe uma variação apenas no nível das séries, uma vez que as tendências das mesmas são muito parecidas. Vale observar, também, que conforme a idade do equipamento vai avançando a curva tende a tornar-se mais suave. Além disso, é perceptível que o formato geométrico declinante levantado nos estudos resenhados no início do capítulo, ajusta-se bem aos dados coletados.

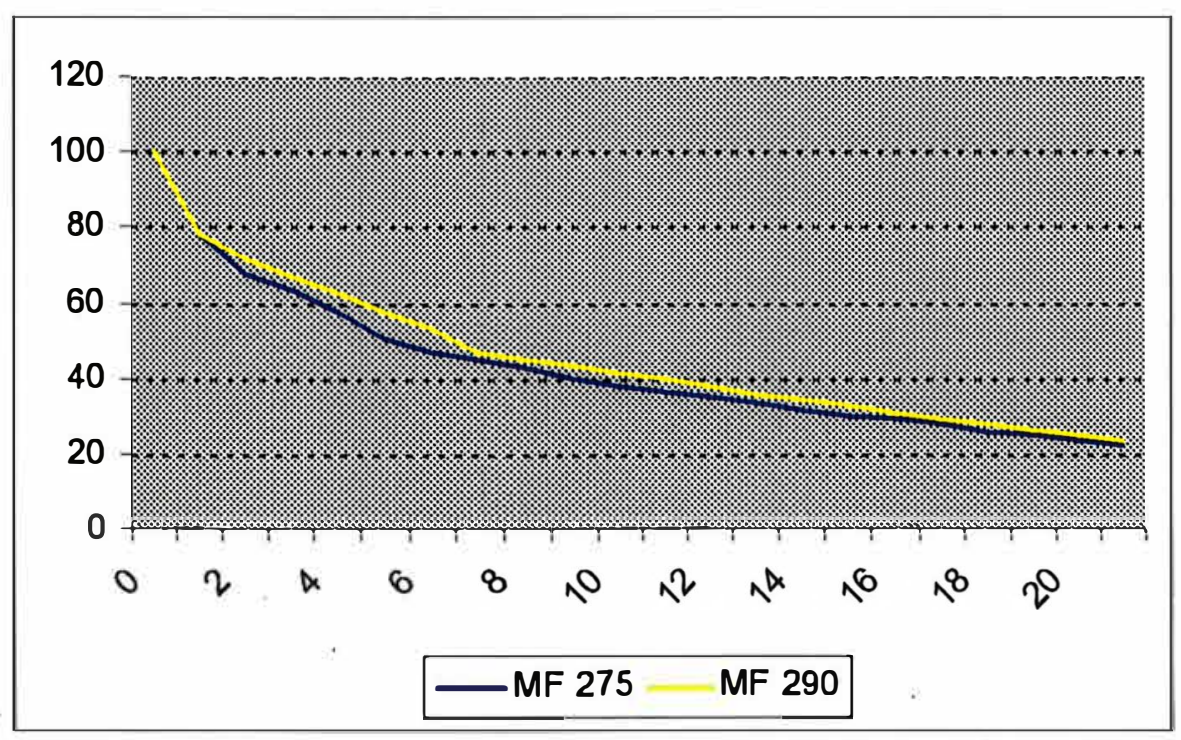

Figura 3 - Índice de Preço Médio dos Tratores Massey Fergusson 275 e 290 com

\section{Zero a 21 anos de Uso (\% do trator novo)}

Fonte: O Estado de São Paulo (vários números entre 1997-1998)

As séries apresentadas na figura 3 encontram-se em nível. Ocorre que o interesse maior se encontra na primeira diferença da série, uma vez que se pretende estabelecer o 
padrão de variação dos preços de um ano para o outro. A fim de testar a consistência dos dados realizou-se um estudo de análise da variância das amostras coletadas ${ }^{22}$. O objetivo era tentar saber se existe diferença significativa nas taxas de variação dos preços entre os dois modelos selecionados e entre as diferentes observações coletadas. Realizou-se, então, o teste $\mathrm{F}$ para as médias das diferenças das séries. A hipótese básica adotada foi a de que as médias eram iguais contra a hipótese alternativa das médias diferirem entre si.

Os resultados obtidos não permitem, em nenhum dos casos considerados, rejeitar a hipótese de que as médias são iguais. No caso do MF 275 o valor do teste $\mathrm{F}$ obtido foi igual a 0,1564 contra um valor crítico de 2,0672. Para o MF 290 o valor alcançado foi de 0,0295 contra um $\mathrm{F}^{*}$ crítico equivalente a 2,1639. Quando as duas amostras foram combinadas a fim de se testar se há diferença significativa no padrão de depreciação das duas séries, o resultado obtido foi igual a 0,1109 com um $\mathrm{F}^{*}$ crítico equivalente a 1,7249. Os resultados da análise da variância encontram-se compilados no Apêndice A.

Uma vez que os resultados da análise da variância não permitiram rejeitar a hipótese das médias das séries diferirem entre si, passou-se a trabalhar com a média das amostras das duas séries. A figura 4 apresenta as séries das médias das diferenças dos preços dos tratores MF 275 e MF 290. Note-se que existe uma queda expressiva do preço do trator nos primeiros anos de uso e que, com o passar do tempo, as variações anuais vão se tornando mais suaves, estabilizando-se ao redor de $5 \%$ ao ano.

\footnotetext{
${ }^{22}$ Para uma apresentação da análise da variância ver Koutsoyiannis (1977).
} 


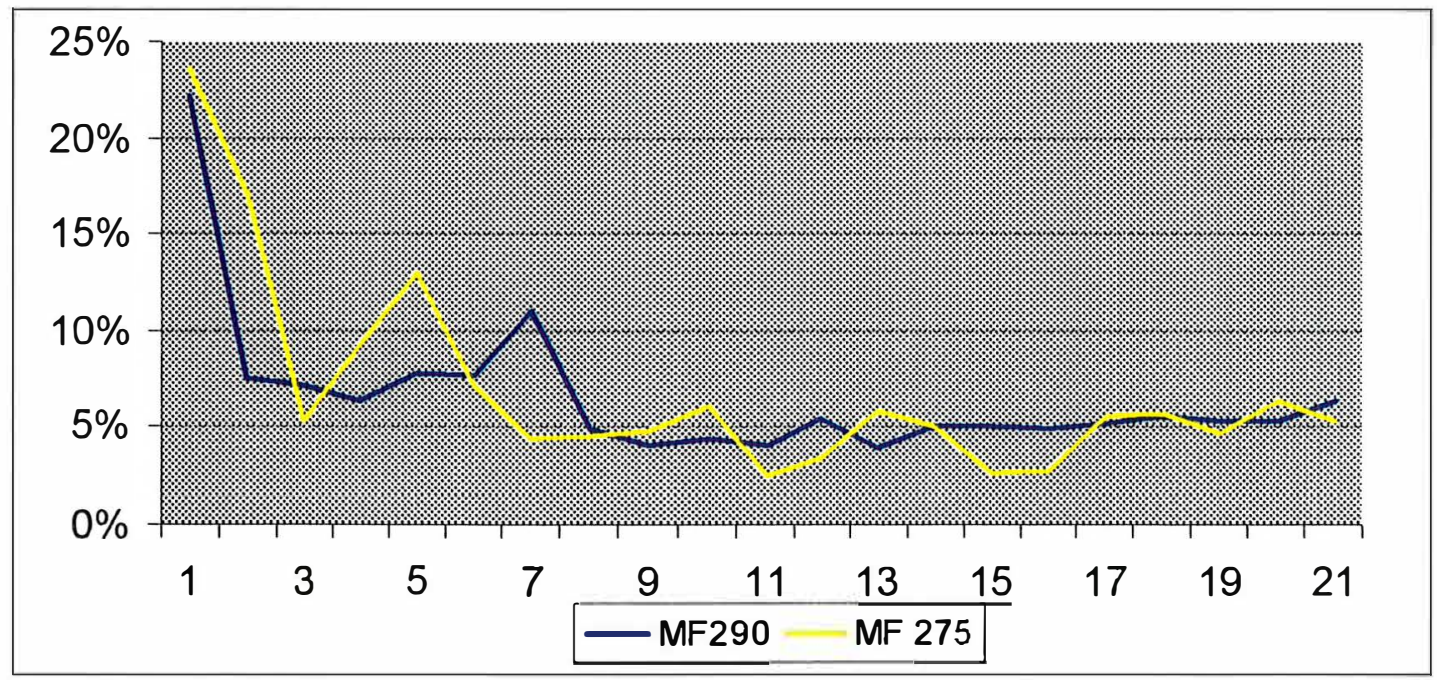

Figura 4 - Taxa Média de Variação Anual dos Preços dos Tratores Massey Fergusson 275 e 290 em 21 anos de Uso

Fonte: O Estado de São Paulo (vários números entre 1997-1998)

Uma vez determinadas as séries a serem consideradas na análise econométrica o problema que se coloca é o estabelecimento da taxa média de depreciação. Uma primeira possibilidade seria tirar a média das diferenças das séries. Ocorre que esse procedimento levaria a uma estimativa um tanto viesada para cima. Pode-se notar, ao observar a figura 4, que nos primeiros anos de vida do trator a redução do preço do mesmo é bastante acentuada (quase $25 \%$ em um ano). Certamente essa redução não reflete a diminuição do valor produtivo do equipamento, uma vez que o trator estará no auge de sua capacidade. Esta queda acentuada no preço do trator semi-novo parece ser muito mais um problema clássico de assimetria de informação. $\mathrm{O}$ artigo seminal de Akerlof (1970) resolve a questão: todos os agentes sabem que um certo número de novos tratores são produzidos com defeito; o agente que comprou um trator novo e quer vendê-lo depois de um ano de uso (por qualquer razão que seja), sabe perfeitamente se seu equipamento é ou não defeituoso; o comprador, entretanto, não tem essa informação; assim, só aceita comprar o trator semi-novo com um forte desconto. 
Percebe-se, portanto, que a inclusão dos primeiros anos no cálculo da depreciação média levaria a uma distorção nos resultados ${ }^{23}$.

Como a média da série das diferenças não representaria bem a taxa média de depreciação optou-se por estimá-la econometricamente ${ }^{24}$. A forma da função selecionada foi a geométrica declinante representada pela seguinte equação:

$$
P_{t}=P_{0} \cdot e^{-d t}
$$

onde,

$$
\begin{aligned}
& \mathrm{P}_{\mathrm{t}}=\text { preço no ano } \mathrm{t} \\
& \mathrm{P}_{\mathrm{o}}=\text { preço no ano } 0 \\
& \mathrm{~d}=\text { taxa de depreciação } \\
& \mathrm{t}=\text { tempo }
\end{aligned}
$$

A equação acima foi estimada na forma logarítmica pelo método de Mínimos Quadrados Ordinários. Estimou-se a taxa de depreciação para as séries de preços dos modelos MF 275 e MF 290; estimou-se também a depreciação obtida da junção das observações dos dois modelos de tratores. A tabela 6 sintetiza os principais resultados das regressões.

Percebe-se que os coeficientes estimados são bastante semelhantes nas três séries consideradas. Nota-se que a taxa de depreciação encontra-se próxima de $6,1 \%$ ao ano. Os resultados do teste t e do coeficiente de determinação são elevados em todos os modelos, indicando que o modelo estimado apresenta bom ajustamento. $\mathrm{O}$ único problema apresentado nas regressões é a presença de autocorrelação nos resíduos. $\mathrm{O}$

\footnotetext{
${ }^{23}$ Griliches (1960a) já havia chamado atenção para o fato da excessiva redução no preço dos tratores nos primeiros anos de vida. Por julgar que essa queda não representava a diminuição no valor produtivo do trator o autor recomendava que esses anos fossem extraídos do cálculo da depreciação média.

${ }^{24}$ Foram testadas diferentes especificações para a função de depreciação; aquela que apresentou melhor ajustamento foi a especificada em (4.1).
} 
teste de Durbin-Watson encontrado para as séries do MF 275, MF 290 e para a combinação de ambas foi, respectivamente, igual a $0,34,0,48$ e 0,41.

Tabela 6 - Coeficiente de Depreciação Estimado Para os Preços de Tratores MF 275, MF 290 e Para a Combinação das Duas Séries

\begin{tabular}{lcccc}
\hline Série de Preços & Coeficiente Estimado (d) & Erro Padrão & Teste t & R2 \\
\hline MF 275 & $-0,0615$ & 0,0031 & $-20,0913$ & 0,9528 \\
MF 290 & $-0,0610$ & 0,0023 & $-26,4716$ & 0,9723 \\
MF 275+MF 290 & $-0,0617$ & 0,0026 & $-24,0704$ & 0,9666 \\
\hline
\end{tabular}

A taxa de depreciação adotada foi de $6 \%$ ao ano, uma vez que a presença de autocorrelação não altera a tendenciosidade do estimador. O cálculo do valor do estoque foi realizado com base nesse número, embora a taxa de $7 \%$ ao ano também tenha sido adotada com o intuito de medir a sensibilidade dos resultados. Observe-se que o valor adotado é bem inferior aos detectados nos EUA, que em geral giravam ao redor de 11 a 18,5\% ao ano (vide Griliches, 1963b). O trabalho de Barros (1980), como já mencionado, havia encontrado para o Brasil uma taxa de depreciação equivalente a 1,5\% ao ano para o período de 1961 a 1979.

\section{4 - A construção do estoque de tratores}

Como ensina Solow (1963, página 78), o primeiro passo a ser tomado quando da construção do estoque de capital é a determinação da vida útil do equipamento. Para poder acumular as vendas anuais é necessário saber quanto tempo atrás deve-se retroceder. A forma ideal de se estabelecer o período de vida do equipamento seria fazer uso de informações acerca da taxa de mortalidade do bem (vide a respeito o excelente estudo de Cramer, 1958). Caso a distribuição de mortalidade fosse conhecida seria possível estabelecer com boa precisão qual a distribuição etária da frota, bem como a 
vida útil máxima do equipamento. Ocorre que não foi encontrado nenhuma fonte de dados que permitisse estabelecer a distribuição da mortalidade de tratores no Brasil.

Dessa maneira, a primeira hipótese levantada foi a de utilizar a série de depreciação estimada na seção anterior. Estabelecendo um preço de sucata do trator (por exemplo, igual a $10 \%$ do valor original do mesmo), seria possível verificar quantos anos seriam necessários para o preço do trator chegar nesse valor. Admitindo-se a depreciação de 6\% ao ano, o trator chegaria a 10\% do seu valor original com 37 anos de uso; com uma taxa de depreciação de $7 \%$ ao ano seriam necessários 32 anos. O problema que surge com um procedimento dessa natureza é que a quantidade de tratores acumulada em 37 anos supera significativamente os dados levantados pelo Censo Agropecuário. Como essa é a melhor fonte de dados disponível quanto ao tamanho da frota de tratores, não fazia sentido algum seguir essa opção.

Assim, o caminho trilhado seguiu por outra direção. Com base nos dados de estoque publicados no Censo Agropecuário e de posse das séries de vendas anuais de tratores de rodas, somaram-se ano a ano as vendas até chegar num valor equivalente ao do Censo. Percebeu-se então que era necessário acumular 21 a 22 anos de vendas. Dessa maneira a vida útil do trator adotada no presente trabalho foi de 21 anos.

Este ponto merece ser melhor elaborado. A hipótese simplificadora adotada no presente estudo é a de que todos os tratores de roda no Brasil tem uma vida útil equivalente a 21 anos; a partir dessa data os tratores deixam de trabalhar. Ora, é claro que esse procedimento não condiz perfeitamente com a realidade, uma vez que existe uma distribuição de mortalidade da frota: alguns tratores deixarão de operar no primeiro ano de vida, em decorrência de algum acidente, por exemplo; outros, entretanto, trabalharão muito mais do que 21 anos. Contudo, como já dito, não existe informação conhecida que dê conta dessa distribuição de mortalidade. Portanto, o procedimento adotado parece ser o melhor possível.

Vale observar, entretanto, que a série de preços de tratores usados computava tratores com até 21 anos de idade. Esse fato pode ser um indicador da não existência de 
um volume expressivo de negócios com tratores acima dessa idade, posto que os dados foram levantados junto a diversos revendedores do Estado de São Paulo. A coincidência desses dois números pode ser um sinalizador da consistência da hipótese simplificadora adotada.

A essência do método adotado foi a seguinte: partindo do ano de 1995, somou-se o valor correspondente a 21 anos de vendas de tratores no mercado interno (de 1974 a 1995). Dessa maneira chegou-se ao número total de tratores existentes em 1995. Para o ano de 1994, somou-se as vendas de tratores entre os anos de 1973 e 1994; para 1993, adicionou-se o período de 1972 até 1993, e assim sucessivamente.

Ao somar os 21 anos de consumo aparente de tratores de rodas chega-se a valores bem próximos dos fornecidos pelo Censo para os anos de 1985 e 1995. Para os anos anteriores a 1985, entretanto, passou a aumentar a distância entre o estoque calculado e o fornecido pelo Censo. Para que os dados continuassem próximos fez-se necessário diminuir o número de anos acumulados para 19. Dessa maneira, o estoque de 1984 foi composto pela agregação das vendas de tratores ao mercado interno entre os anos de 1965 e 1984; o número total de tratores em 1983 foi composto pelas vendas de 1964 a 1983, e assim sucessivamente. Entre 1975 e 1985 os dados obtidos no presente trabalho e os divulgados pelo Censo, seguiram juntos. A partir de então foi necessário reduzir, mais uma vez, para 18 o número de anos acumulados. Esses resultados indicam que, de certa máneira, a frota brasileira de tratores envelheceu ao longo do período considerado.

A tabela 7 apresenta o número total de tratores levantados pelos Censos de $1970,1975,1980,1985$ e 1995, bem como os valores estimados no trabalho conforme a metodologia descrita acima. Pode-se notar que a diferença entre os estoques é relativamente pequena, ao redor de $2 \%$. Note-se que essa diferença é tanto positiva quanto negativa, o que é um indicador da não existência de um viés no procedimento adotado. Vale ressaltar, novamente, que ao balizar o estoque estimado nos dados dos 
Censos Agropecuários estar-se-á atrelando o estudo à melhor base de informação disponível sobre o tamanho do estoque de tratores.

Tabela 7 - Número de Tratores de Roda Presentes nos Censos Agropecuários, Número de Tratores Estimados e Diferença Percentual dos Estoques

\begin{tabular}{cccc}
\hline Anos & Valores do Censo & Valores Estimados & Diferença \\
\hline 1970 & 165.870 & 165.332 & $+0,3 \%$ \\
1975 & 323.113 & 331.214 & $-2,5 \%$ \\
1980 & 545.205 & 555.124 & $-1,8 \%$ \\
1985 & 652.049 & 663.487 & $-1,8 \%$ \\
1995 & 803.676 & 788.574 & $+1,9 \%$ \\
\hline
\end{tabular}

Fonte: Censo Agropecuário

Uma vez determinada a vida útil dos tratores foi possível estabelecer, em cada ano, o número de tratores de rodas acumulados. Foi possível também dimensionar o número total de cavalos acumulados. Como já mencionado, os dados da ANFAVEA separam as vendas ao mercado interno em quatro classes de potência: i) até 49 c.v.; ii) de 50 a 99cv; iii) de 100 a 199 c.v.; iv) acima de 200 c.v.. Para estimar o número total de cavalos acumulados multiplicou-se, ano a ano, o número de tratores vendidos por classe de potência pelos seguintes valores: para o primeiro grupo adotou-se o limite de cima da classe (49 c.v.); para as classes intermediárias adotaram-se os valores médios do grupo (7.5 e 150 c.v., respectivamente) e para a última categoria foi escolhido o valor de 200 c.v.. Uma vez calculado o volume anual de cavalos vendidos ao mercado interno somou-se, a cada ano, o número correspondente a 21 anos de vendas para o período 1995 a 1986, 19 anos para 1985 a 1976 e 18 anos para os anos de 1975 a 1970. Com esse procedimento foram obtidas as séries de estoque medidas em número total de tratores e de cavalos. 
Restava calcular o valor do estoque. Para tanto fez-se uso das séries de depreciação construídas com base nos valores de 6 e de $7 \%$ ao ano. Adotando-se os preços de tratores novos ${ }^{25}$ com potências equivalente às selecionadas anteriormente para a série de potência, multiplicaram-se esses preços pelos valores registrados na curva teórica de depreciação. Dessa maneira obteve-se o preço do trator para cada ano de uso (de zero a 21 anos). A partir deste ponto o procedimento adotado foi análogo aos das duas outras séries só que agora as quantidades foram multiplicadas pelo preço do trator no respectivo ano de uso. Deslocando-se ano a ano a somatória de 21 anos da multiplicação das vendas anuais pelo respectivo preço do trator, chegou-se às séries de valor do estoque para as depreciações de 6 e de $7 \%$.

A tabela 8 apresenta as quatro séries construídas de estoque de tratores de rodas. As séries de valor do estoque estão expressas em reais de dezembro de 1995 e as demais em número de tratores e número de cavalos-vapor. A fim de fazer uma análise comparativa das séries os dados foram transformados em índices tomando o ano de 1970 como base. Os movimentos das quatro séries podem ser melhor observados com auxílio da figura 5 abaixo.

Um primeiro ponto refere-se à comparação entre as duas taxas de depreciação adotadas. Note-se que enquanto o estoque de tratores era relativamente pequeno e as taxas de investimento eram altas (início dos anos 70), as duas medidas não se distanciaram múito. Entretanto, conforme o estoque foi envelhecendo, aumentando a proporção de tratores antigos, começou a haver maior diferença entre as séries. Enquanto em 1980 essa distância era de 5\%, em 1997 passou a 10\%. Assim, é possível verificar que pequenas variações na taxa de depreciação adotada provocam mudanças apreciáveis no longo prazo, dependendo dos ciclos de investimento.

Aspecto marcante a ser destacado diz respeito é o processo de envelhecimento do estoque de tratores no Brasil. O valor da frota atingiu o auge no final dos anos 80 , quando seu valor chegou a ser quatro vezes maior do que em 1970. Entretanto, a partir

\footnotetext{
${ }^{25}$ Os preços dos tratores novos são do IEA e encontram-se listados no apêndice A.
} 
de então, a série mudou claramente de tendência, tendo reduzido seu valor em mais do que $20 \%$. É perceptível, portanto, que as alterações nas condições econômicas nos anos 80 afetaram fortemente os investimentos. Note-se que o valor do capital em 1995 é equivalente ao valor de 1979.

\section{Tabela 8 - Estoque de Tratores Medido em Valor, Número de Tratores e Número de Cavalos Vapor Entre 1970 e 1997 (valores em R\$ de dezembro de 1995)}

\begin{tabular}{|c|c|c|c|c|c|c|c|c|}
\hline ANO & \multicolumn{2}{|c|}{ VALOR ESTOQUE (7\%) } & \multicolumn{2}{|c|}{ VALOR ESTOQUE ( $6 \%)$} & \multicolumn{2}{|c|}{ ESTOQUE (número) } & \multicolumn{2}{|c|}{ ESTOQUE (c.v.) } \\
\hline 1970 & 2.216 .893 .191 & 100 & 2.364 .024 .403 & 100 & 165.332 & 100 & 10.269 .630 & 100 \\
\hline 1971 & 2.513.733.293 & 113 & 2.665.012.227 & 113 & 180.370 & 109 & 11.700 .800 & 114 \\
\hline 1972 & 2.984 .340 .359 & 135 & 3.148.990.435 & 133 & 208.148 & 126 & 13.925 .420 & 136 \\
\hline 1973 & 3.581.177.305 & 162 & 3.750 .486 .615 & 159 & 235.602 & 143 & 16.504 .690 & 161 \\
\hline 1974 & 4.320 .401 .529 & 195 & 4.508 .690 .361 & 191 & 276.599 & 167 & 19.914.595 & 194 \\
\hline 1975 & 5.287.264.571 & 238 & 5.502 .319 .660 & 233 & 331.214 & 200 & 24.415 .000 & 238 \\
\hline 1976 & 6.324 .430 .051 & 285 & 6.579 .454 .481 & 278 & 395.181 & 239 & 29.550 .385 & 288 \\
\hline 1977 & 6.915 .980 .279 & 312 & 7.210 .577 .495 & 305 & 436.978 & 264 & 32.889 .405 & 320 \\
\hline 1978 & 7.315 .001 .183 & 330 & 7.652 .312 .868 & 324 & 471.657 & 285 & 35.778 .940 & 348 \\
\hline 1979 & 7.873.035.586 & 355 & 8.257 .608 .492 & 349 & 516.777 & 313 & 39.768 .195 & 387 \\
\hline 1980 & 8.379 .544 .448 & 378 & 8.804 .161 .534 & 372 & 555.124 & 336 & 42.892 .740 & 418 \\
\hline 1981 & 8.370 .889 .946 & 378 & 8.843 .917 .821 & 374 & 575.220 & 348 & 44.676 .535 & 435 \\
\hline 1982 & 8.280 .028 .376 & 373 & 8.796 .953 .015 & 372 & 590.603 & 357 & 46.077 .160 & 449 \\
\hline 1983 & 8.138 .856 .108 & 367 & 8.693 .753 .127 & 368 & 601.926 & 364 & 47.283 .305 & 460 \\
\hline 1984 & 8.425 .968 .866 & 380 & 9.013 .134 .964 & 381 & 631.013 & 382 & 49.862 .890 & 486 \\
\hline 1985 & 8.698 .409 .231 & 392 & 9.323 .819 .857 & 394 & 663.487 & 401 & 52.606 .360 & 512 \\
\hline 1986 & 9.152 .155 .012 & 413 & 9.837 .615 .374 & 416 & 718.652 & 435 & 56.813 .395 & 553 \\
\hline 1987 & 9.348 .191 .544 & 422 & 10.073 .670 .425 & 426 & 749.686 & 453 & 59.475 .630 & 579 \\
\hline 1988 & 9.321 .966 .448 & 420 & 10.085 .359 .490 & 427 & 770.119 & 466 & 61.418 .925 & 598 \\
\hline 1989 & 9.232 .202 .915 & 416 & 10.034 .915 .082 & 424 & 790.239 & 478 & 63.158 .390 & 615 \\
\hline 1990 & 9.024 .648 .926 & 407 & 9.859 .263 .812 & 417 & 801.914 & 485 & 64.149 .070 & 625 \\
\hline 1991 & 8.655 .647 .892 & 390 & 9.518 .129 .681 & 403 & 805.559 & 487 & 64.609 .995 & 629 \\
\hline 1992 & 8.207 .968 .193 & 370 & 9.087 .758 .288 & 384 & 800.949 & 484 & 64.169 .575 & 625 \\
\hline 1993 & 8.022 .364 .032 & 362 & 8.904 .959 .846 & 377 & 800.766 & 484 & 64.392 .355 & 627 \\
\hline 1994 & 8.187 .744 .116 & 369 & 9.062 .216 .740 & 383 & 809.941 & 490 & 65.471 .255 & 638 \\
\hline 1995 & 7.841 .193 .641 & 354 & 8.698 .120 .563 & 368 & 788.574 & 477 & 63.830 .620 & 622 \\
\hline 1996 & 7.323 .471 .455 & 330 & 8.152 .600 .713 & 345 & 753.037 & 455 & 61.102 .390 & 595 \\
\hline 1997 & 6.930 .888 .966 & 313 & 7.714 .061 .477 & 326 & 711.661 & 430 & 57.926 .220 & 564 \\
\hline
\end{tabular}

A inspeção da figura 5 permite melhor visualização dos movimentos relativos das séries. A taxa de crescimento do valor do estoque foi maior do que a taxa de crescimento do número de tratores no início dos anos 70 até meados dos 80 . Esse 
movimento é típico, como apontava Griliches (1963a), de economias que estão em expansão. Partindo de um estoque pequeno, altos acréscimos anuais elevam o valor do estoque mais do que proporcionalmente ao número. Percebe-se, contudo, que essa tendência foi revertida e, já a partir dos anos 80 , a taxa de decréscimo do valor tornou-se bem mais acentuada do que a do número de tratores, indicando o envelhecimento da frota. Vale notar que o estoque de tratores chegou a aumentar quase cinco vezes em número entre 1970 e 1990. O que mais chama atenção, contudo, é a evolução da potência acumulada. Entre 1970 e 1994 o estoque de tratores medido em potência aumentou mais do que seis vezes, sugerindo uma elevação da potência média dos tratores. Ainda assim, percebe-se que todas as séries indicam uma tendência de redução do estoque a partir de 1994, o que poderia, inclusive, estar sinalizando um ambiente de grande incerteza em futuro não muito distante.

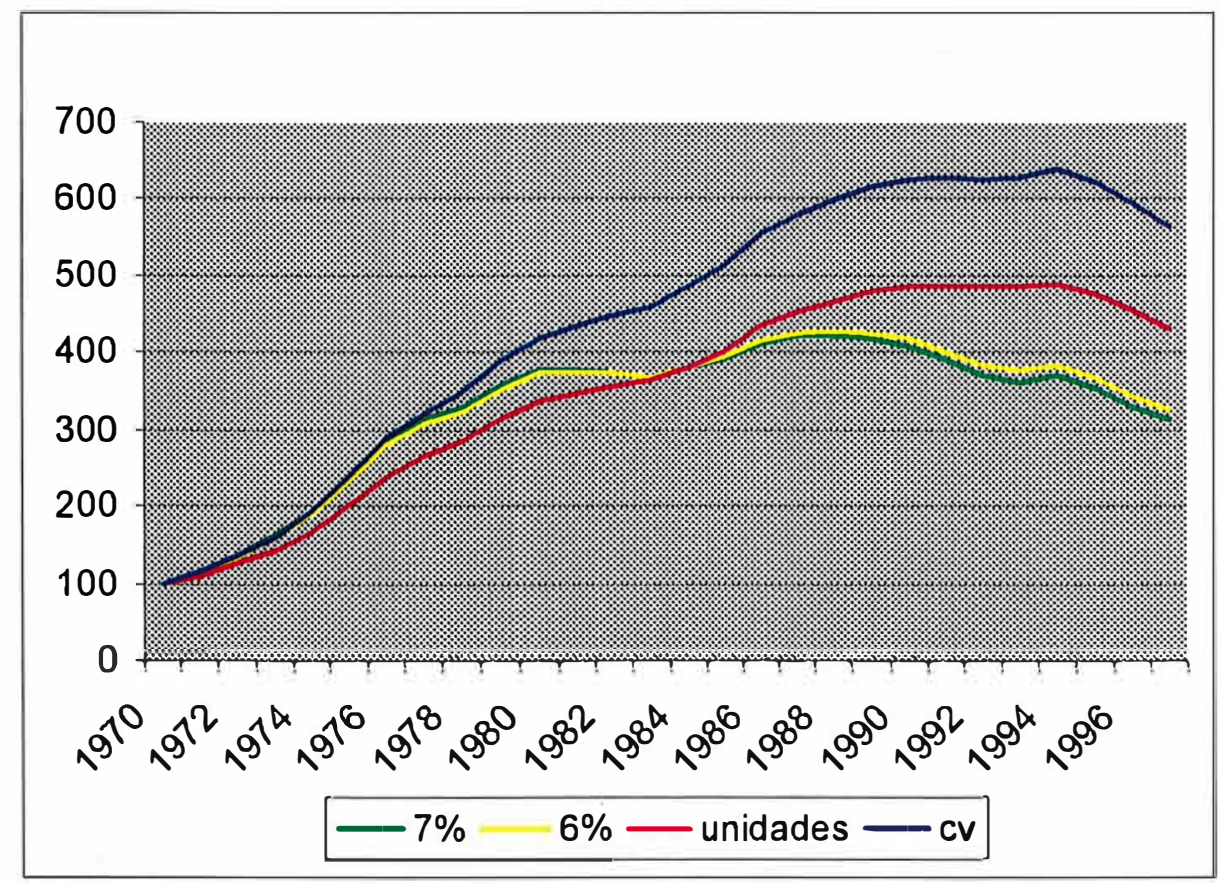

Figura 5 - Estoque de Tratores Medido em Valor, Número de Tratores e Número de Cavalos Vapor Entre 1970 e 1997 (1970=100) 
O processo de acumulação de capital na agricultura nos anos 70 e meados de 80 foi, de fato, expressivo. $\mathrm{O}$ aumento no número de tratores no país fez com que o número de hectares por trator caísse sensivelmente. Enquanto em 1973 eram cultivados 165 ha por trator, em 1995 esse valor passou a 64 (figura 6).

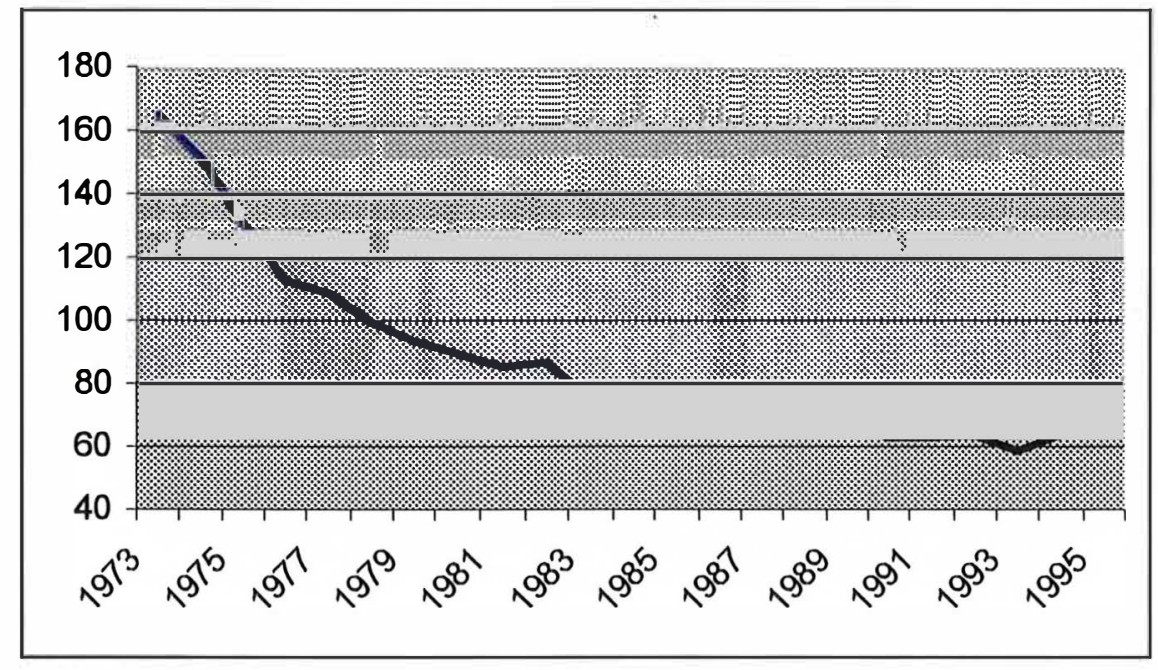

Figura 6 - Número de Hectares Cultivados por Trator Entre 1973 e 1995

A tabela 9 permite que se tenha melhor noção do processo de acumulação de capital na agricultura brasileira no período de 1973 a 1995. Observa-se que a relação capital/trabalho aumentou consideravelmente no período. Enquanto em 1973 existia 1 trator para 63 pessoas ocupadas na agricultura, em 1995 esse número correspondia a 18. Entretanto, quando se considera o valor do capital por pessoa, percebe-se que esse aumentou até início dos anos 90, quando a partir de então começou a reduzir (houve entre 1990 e 1995, uma queda de 10\% no valor do estoque de capital por pessoa ocupada). Por fim, pode-se notar que de fato houve uma elevação da potência média no período estudado, atingindo-se a média de $81 \mathrm{cv}$ por trator nos anos 90. 
Tabela 9 - Número de Hectares por Trator, Pessoas por Trator, Cavalos -Vapor por Pessoa e Valor do Capital por Pessoa na Agricultura Brasileira, 1973 a 1995

\begin{tabular}{lcccc}
\hline Ano & Hectares por Trator & Pessoas por Trator & Cavalos Vapor por Trator & Capital (R\$) por Pessoa \\
\hline 1973 & 165 & 64 & 70 & 239 \\
1974 & 151 & 53 & 72 & 292 \\
1975 & 131 & 44 & 74 & 363 \\
1976 & 113 & 36 & 75 & 441 \\
1977 & 108 & 35 & 75 & 458 \\
1978 & 99 & 31 & 76 & 506 \\
1979 & 93 & 28 & 77 & 548 \\
1980 & 89 & 23 & 77 & 662 \\
1981 & 85 & 23 & 78 & 629 \\
1982 & 87 & 24 & 78 & 586 \\
1983 & 75 & 22 & 79 & 621 \\
1984 & 79 & 24 & 79 & 563 \\
1985 & 78 & 23 & 79 & 573 \\
1986 & 75 & 20 & 79 & 639 \\
1987 & 71 & 19 & 79 & 662 \\
1988 & 72 & 18 & 80 & 655 \\
1989 & 70 & 18 & 80 & 658 \\
1990 & 63 & 18 & 80 & 636 \\
1991 & 63 & 16 & 80 & 689 \\
1992 & 63 & 19 & 80 & 549 \\
1993 & 58 & 18 & 80 & 547 \\
1994 & 63 & 17 & 81 & 579 \\
1995 & 64 & 18 & 81 & 540 \\
\hline
\end{tabular}

Uma última observação antes de adentrar nas questões relativas à mensuração da produtividade total dos fatores. É importante que se tenha em mente a distância entre as medidas do capital adotadas no presente estudo e outra freqüentemente utilizada. Na figura 7 encontra-se o estoque em número de tratores aqui estimado (linha verde) e o estoque construído admitindo-se que haja uma depreciação linear de $10 \%$ ao ano (ou seja, que um trator tenha 10 anos de vida útil). Note-se que em 1997 existiria uma distância entre as séries de mais do que 500.000 tratores. 


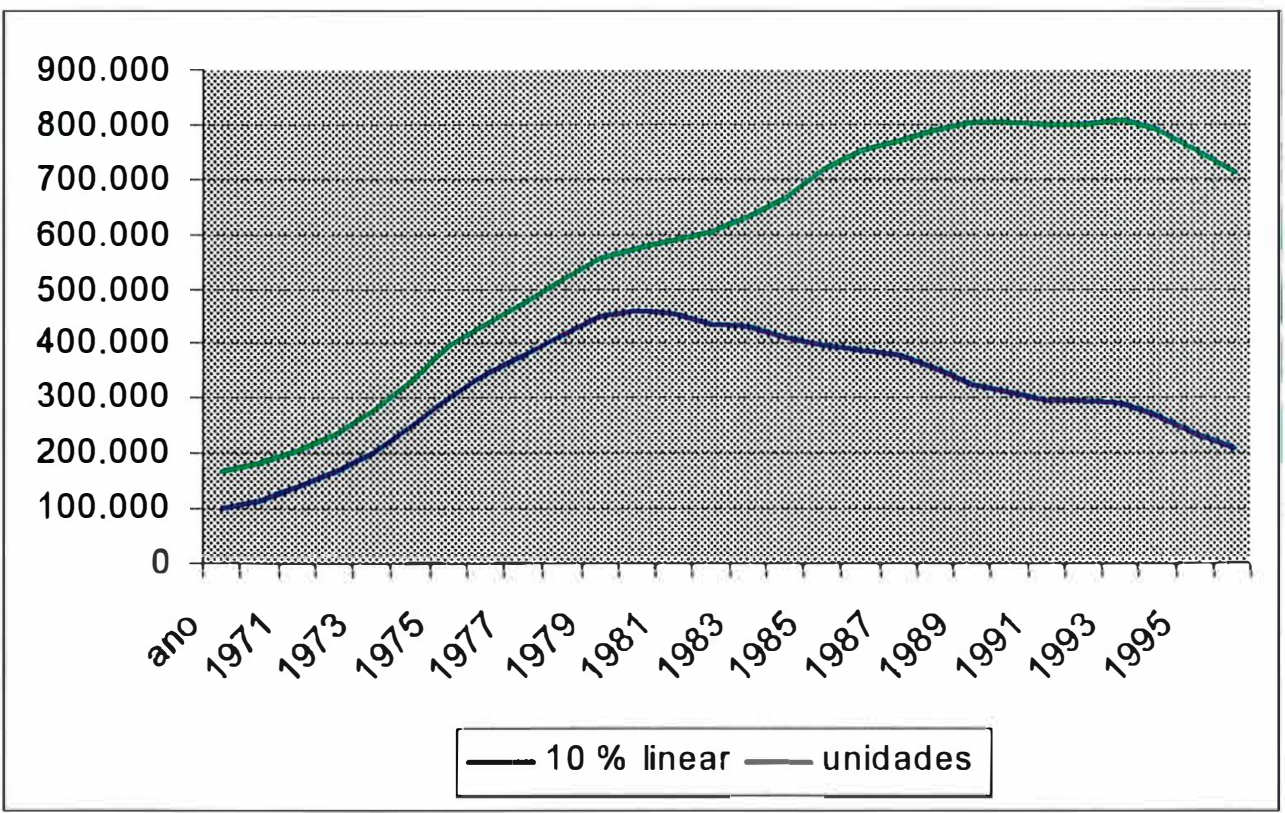

Figura 7 - Comparação dos Estoques de Tratores Calculados com Taxa de Depreciação Linear (10\%) e Estoque Baseado nos Censos Agropecuários entre 1970-1997 (em unidades) 


\section{5 - PRODUTIVIDADE TOTAL DOS FATORES NA AGRICULTURA BRASILEIRA}

Uma característica que vem marcando os diferentes estudos relativos aos ganhos na produtividade total dos fatores (PTF) na agricultura é a grande variância de resultados encontrados. Os números oscilam entre $-1,66 \%$ e $4.3 \%$ ao ano ${ }^{26}$. O objetivo do presente capítulo é mostrar que a base das diferenças dos resultados encontra-se na construção das séries dos fatores de produção. Em especial, pretende-se avaliar as oscilações da PTF em decorrência das diferentes formas de medida do capital. O capítulo segue a seguinte sequência: na primeira parte apresenta-se o conceito; na segunda, suas formas de mensuração; a terceira descrevem-se os dados; e, por fim, expõem-se os resultados.

\section{1 - O conceito}

O produto de uma economia é dado pela quantidade de insumos usados na produção e pela produtividade desses insumos, ou seja, pela tecnologia usada para transformar os insumos em produto (Pinheiro, 1989). As alterações no produto são resultantes das variações nas quantidades dos fatores ou nas mudanças da produtividade total dos fatores (PTF) . Assim, percebe-se que o conceito de produtividade total dos

\footnotetext{
${ }^{26}$ Ao longo do capítulo será apresentada uma resenha dos estudos de produtividade total dos fatores na agricultura brasileira e internacional.
} 
fatores é, na verdade, relativamente simples: consiste na parcela do crescimento do produto não explicada pela variação na quantidade dos insumos.

Embora o conceito da PTF seja simples, sua mensuração e relação com a teoria econômica não o são. Existe uma extensa discussão na literatura quanto ao significado preciso dessa medida. Frequientemente, relaciona-se a PTF com a taxa de progresso tecnológico. A variação na produtividade total seria, nessa visão, conseqüência do desenvolvimento e da difusão de novas tecnologias ao longo da cadeia produtiva, fazendo com que uma dada quantidade de insumo gere maior volume de produto.

Desde logo essa associação foi muito criticada. Como é fácil perceber pela própria definição do conceito, a produtividade total dos fatores é o resíduo da diferença entre o produto e a soma dos insumos mensurados. Ora, é possível que nem tudo nessa diferença seja progresso tecnológico strictu sensu. Se, por um lado, houver ganhos em escala ou se, por outro, mudanças institucionais permitirem ganhos em eficiência alocativa, haverá um aumento na PTF que não tem nenhuma correlação com melhoria da tecnologia. Percebe-se, portanto, que o conceito carrega em si uma série de determinantes de difícil desagregação. Como coloca Nelson (1981), em trecho cunhado por Pinheiro (1989):

"Todos sabem que o resíduo responde por uma mistura de fatores, mas estes são de difícil identificação. Se esta "medida de nossa ignorância" não é completamente misteriosa, certamente não é bem compreendida."

(página 1035)

Boa parte dos esforços empíricos dos estudiosos do crescimento passou a se concentrar em quais seriam as causas das variações no resíduo. Desde os anos 60 percebeu-se que parte da explicação estaria nas mudanças na qualidade dos insumos. $\mathrm{Na}$ 
agricultura, os estudos de Griliches (op.cit.) foram pioneiros nessa direção. A idéia básica por trás dessa linha de pesquisa é que boa parte do progresso tecnológico é fisicamente incorporada ao fator de produção, de tal sorte que sua qualidade é alterada, tornando-o mais produtivo. O trecho a seguir, extraído de Griliches (1960b), resume precisamente a questão:

"Existem poucas dúvidas que a qualidade da maioria dos insumos agrícolas mudou substancialmente nos últimos 20 anos. Tratores aumentaram em tamanho e em versatilidade, a concentração de nutrientes nos fertilizantes aumentou cerca de 50\%, e houve uma elevação no nível educacional da força de trabalho agrícola. Está claro que nós queremos que nossas medidas dos insumos consigam contabilizar algumas dessas mudanças, isto é, mudanças na capacidade média dos fatores. Se quisermos ou não medir todas as mudanças possíveis na qualidade é muito mais uma questão semântica do que de substância. A semente de milho híbrido pode ser vista tanto como uma mudança na qualidade da semente quanto como "mudança tecnológica". Uma vez que estamos interessados em explicar o crescimento, não interessa se colocarmos a mudança tecnológica na categoria de "mudança dos insumo" ou na categoria de "mudança da produtividade", contanto que a coloquemos em algum lugár e saibamos onde está. Mas interessa muito que procuremos medir essa mudança da melhor forma possível uma vez que ela é uma fonte muito importante na variação do produto".

(página 1411)

O trecho acima sugere que caso os insumos sejam medidos adequadamente, dando conta das variações na qualidade dos mesmos, o resíduo poderia ser reduzido a quase zero. Solow (1963) já havia aventado essa possibilidade, muito embora julgasse 
não ser factível na prática reduzir tanto o resíduo (ver página 39). O autor chama atenção, entretanto, que reduzir o resíduo a zero não significa dizer que o progresso tecnológico não teria mais importância no longo prazo; significaria apenas que os efeitos da tecnologia poderiam ser imputados de volta aos insumos ${ }^{27}$.

Esse aspecto da mudança na qualidade dos insumos e seus impactos na medida da PTF é uma das preocupações do presente capítulo. A idéia a ser perseguida é que, como visto no capítulo anterior, o estoque de tratores no Brasil apresentou clara tendência de aumento na potência média da frota. Essa mudança de qualidade será incorporada ao cálculo da PTF, avaliando-se o impacto das diferentes formas de medida de estoque nos valores estimados para a PTF.

Existem, de acordo com Bonelli e Fonseca (1998), três formas de cômputo da PTF, quais sejam: i) o método da contabilidade do crescimento; ii) o método da função de produção; iii) o método das razões de produtividade, que pode ser dividido em aditivo ou geométrico ${ }^{28}$. Em geral, segundo os mesmos autores, a escolha do método adotado é determinado, em boa medida, pela disponibilidade de dados. Entretanto, Fulginiti e Perrin (1998) sugerem que se possível for, devem ser testadas diferentes formas de medida a fim de avaliar robustez dos resultados.

O presente estudo utilizará os três métodos de cálculo. Assim como Bonelli e Fonseca (1998), far-se-á uso da estimação da função de produção agregada do setor com o intuito de estabelecer as participações dos fatores no produto e de testar a hipótese de retornos constantes à escala. Como será visto mais adiante, nos estudos de produtividade total dos fatores três componentes afetam e diferenciam os resultados, quais sejam: i) existência de retornos à escala; ii) a determinação do peso relativo dos fatores de produção; e , principalmente, iii) a qualidade das séries de fatores. A estimação da função de produção auxiliará nos dois primeiros itens. O terceiro item já

\footnotetext{
${ }^{27}$ Parte da desconfiança de Solow se baseia no fato de que nem toda tecnologia é incorporada aos insumos. Existem aquelas técnicas não-incorporadas tais como organização da produção, ganhos com experiência (learning-by-doing), efeitos externos da tecnologia, etc.

${ }^{28}$ Esse último é também conhecido como método não paramétrico.
} 
foi elaborado no capítulo anterior, ao serem construídas as séries de capital que são, reconhecidamente, de difícil estimação (Solow 1963, Bonelli e Pessoa 1998, entre tantos).

Uma vez estabelecida a participação dos fatores a partir dos coeficientes das funções estimadas, o cálculo da PTF será feito através do método da contabilidade. Serão testados, nessa formulação, os efeitos das diferentes formas de medida do estoque de capital na PTF. A fim de avaliar a consistência dos resultados do método da contabilidade, a PTF será calculada também pelo método não paramétrico, fazendo uso do índice de Tornquist-Theil. Além de permitir a comparação dos resultados, o próprio processo de construção do índice possibilitará a quantificação das participações dos fatores no produto total, permitindo que as estimativas da função de produção possam ser testadas. Na realidade, ao longo do desenvolvimento do trabalho, percebeu-se que os diferentes métodos selecionados foram se tornando crescentemente complementares, $\mathrm{o}$ que conferiu certa solidez aos resultados, como será visto mais adiante. Antes, entretanto, faz-se necessário apresentar formalmente os três procedimentos adotados. Esse é o objetivo das próximas seções.

\section{2 - Os métodos de cálculo da produtividade total dos fatores}

\subsection{1 - O método da contabilidade}

Como afirma Hulten (1986), a base de todo o procedimento padrão de cálculo da produtividade parte da teoria da função de produção. O clássico artigo de Solow (1957), base do método da contabilidade, parte de uma função de produção igual a

(5.1) $\quad \mathrm{Y}=\mathrm{F}(\mathrm{K}, \mathrm{L}, \mathrm{t})$ 
Onde,

$\mathrm{Y}=$ produto

$\mathrm{K}$ = capital em unidades físicas

$\mathrm{L}=$ trabalho em unidades físicas

$\mathrm{t}$ = variável de tendência

A variável t aparece em $\mathrm{F}$ para representar a mudança técnica. Solow argumenta, entretanto, que a expressão "mudança técnica" indica qualquer tipo de alteração na função de produção. $O$ autor reconhece que variações na capacidade, melhoria na educação do trabalhador, etc, serão computadas como "progresso técnico".

A fim de simplificar a exposição, o autor admite que o progresso é do tipo neutro, ou seja, que não altere as taxas marginais de substituição dos fatores; essa forma de tecnologia provoca apenas alterações na quantidade de produto extraído de dada quantidade de insumos. Assim, nesse caso, a função assume a forma especial,

\section{(5.2) $Y=A(t) f(K, L)$}

em que o fator multiplicativo $\mathrm{A}(\mathrm{t})$ mede os efeitos acumulados das mudanças ao longo do tempo. Diferenciando totalmente a equação (5.2), obtém-se

$$
\dot{Y}=\dot{A} f(K, L)+A \frac{\partial f}{\partial K} \dot{K}+A \frac{\partial f}{\partial L} \dot{L}
$$

onde o ponto acima da variável indica a derivada com relação ao tempo. Dividindo a expressão acima por $\mathrm{Y}$, chega-se a 
(5.4) $\frac{\dot{Y}}{Y}=\frac{\dot{A}}{A}+\frac{\partial Y}{\partial K} \frac{\dot{K}}{Y}+\frac{\partial Y}{\partial L} \frac{\dot{L}}{L}$

$$
A \frac{\partial f}{\partial K}=\frac{\partial Y}{\partial K} \quad \text { e } \quad A \frac{\partial f}{\partial L}=\frac{\partial Y}{\partial L}
$$

com

Multiplicando o segundo termo do lado direito por $\mathrm{K} / \mathrm{K}$ e o terceiro por $\mathrm{L} / \mathrm{L}$, temse

$$
\frac{\dot{Y}}{Y}=\frac{\dot{A}}{A}+E_{K} \frac{\dot{K}}{K}+E_{L} \frac{\dot{L}}{L}
$$

com,

$$
\text { (5.6) } \quad E_{K}=\frac{\partial Y}{\partial K} \frac{K}{Y} \quad \text { e } \quad E_{L}=\frac{\partial Y}{\partial L} \frac{L^{\prime}}{Y}
$$

As expressões apresentadas em (5.6) representam as elasticidades do produto com relação ao capital e ao trabalho.

Em equilíbrio competitivo o valor do produto marginal do capital e do trabalho devem ser iguaiș a seus preços (o valor de aluguel do capital e o valor do salário). Chamando $\mathrm{P}_{\mathrm{K}}, \mathrm{P}_{\mathrm{L}}$ e $\mathrm{P}$ os preços do capital, do trabalho e do produto agregado, respectivamente, tem-se que 
(5.7)

$$
\frac{\partial Y}{\partial K}=\frac{P_{K}}{P} \quad \text { e } \quad \frac{\partial \mathrm{Y}}{\partial \mathrm{L}}=\frac{P_{L}}{P}
$$

Substituindo (5.7) em (5.6), transformam-se as expressões de elasticidade em

$$
\text { (5.8) } \quad W_{K}=\frac{P_{K}}{P} \frac{K}{Y} \quad \text { e } \quad W_{L}=\frac{P_{L}}{P} \frac{L}{Y}
$$

O ponto a ser notado é que as expressões apresentadas em (5.8) representam as participações do capital e do trabalho no produto total e que, dado (5.5), são iguais as elasticidades do produto com relação aos fatores de produção $\left(E_{K}\right.$ e $\left.E_{L}\right)$. Vale observar que sob retornos constantes a escala, $\mathrm{W}_{\mathrm{K}}+\mathrm{W}_{\mathrm{L}}=1$.

Combinando as expressões (5.8) e (5.5) e rearranjando os termos, chega-se a equação da medida da PTF (ou do resíduo de Solow),

(5.9) $\frac{\dot{A}}{A}=\frac{\dot{Y}}{Y}-W_{K} \frac{\dot{K}}{K}-W_{L} \frac{\dot{L}}{L}$

A expressão (5.9) é a equação fundamental da contabilidade do crescimento na sua forma de tempo contínuo. Hulten (1986) afirma que pode ser também chamada de forma do Índice de Divísia.

A expressão fundamental torna explícito o fato de a PTF ser estimada por resíduo. Ademais, é fácil perceber a forte correlação entre ela e a função de produção. 


\subsection{2 - O método da função de produção}

Os estudos de produtividade que fazem uso de estimativas econométricas de funções de produção (ou de funções custo) podem ser divididos em dois grupos: i) funções deterministas; e, ii) funções de fronteira estocástica (Pinheiro, 1989). A distinção básica entre as duas categorias é que enquanto o primeiro grupo estima a função pela média da amostra, no segundo a estimativa é feita computando-se a fronteira de possibilidades de produção das firmas. A idéia associada à função fronteira é a da curva envelope formada pelas firmas com mais altas produtividades.

A distinção entre esses dois grupos ajuda a elucidar mais um componente computado no resíduo que dificulta sua associação direta com o conceito de progresso tecnológico. A idéia básica por trás dessas duas formas de estimar a função de produção é que, numa economia qualquer, existe uma distribuição do nível de produtividade das firmas. Ao estimar a função pela média da amostra e uma vez constatado um deslocamento da mesma, não é possível saber se esse movimento se deu por conta do progresso tecnológico ou se foi resultado do fato da parcela menos produtiva da amostra ter-se aproximado da fronteira. É perfeitamente possível que, em decorrência de alterações no marco institucional, as empresas ganhem eficiência produtiva ao longo do tempo e passem a apresentar ganhos de produtividade. Se esse fosse o caso, o movimento da fronteira não seria decorrente do progresso tecnológico, mas sim de ganhos em eficiência alocativa. Entretanto, ao estimar a fronteira de produção e uma vez detectado um deslocamento da mesma, saber-se-ia com segurança que isso seria devido ao progresso técnico. Tal procedimento permitiria separar ganhos de eficiência de progresso tecnológico.

No início do presente estudo imaginou-se que o conceito da função fronteira seria muito útil para entender as causas do crescimento da agricultura brasileira nos anos 80 e 90. Imaginou-se que ao estimar a função fronteira seria possível avaliar a cada ano do período qual a distância entre produto potencial e produto efetivo. Caso esta distância tivesse diminuído no período, significaria que os ganhos de eficiência alocativa teriam 
aumentado progressivamente. Seria uma forma de computar os efeitos da redução da interferência do Estado no mercado de fatores.

Esse procedimento foi adotado por Kalirajan et alii (1996) para estudar o comportamento do aumento da PTF na agricultura chinesa antes e após as mudanças institucionais adotadas em 1978. Os autores demonstram que os ganhos de produtividade após a reforma foram explicados em boa medida pelo aumento da eficiência produtiva. No Brasil o único estudo encontrado que procurou fazer algo semelhante foi o de Arnade (1992b). O autor estimou uma função custo do tipo Leontief e analisando os resíduos em diversos períodos entre 1968 e 1987, conclui que com a redução dos subsídios houve um aumento na eficiência produtiva.

Procurou-se estimar a função de fronteira estocástica, mas a pequena variância dos dados não permitiu chegar a nenhum resultado. Na realidade, como a cada ano existia apenas uma observação, não havia grandes diferenças dos números entre os anos, o que, se de fato ocorresse, possibilitaria captar a fronteira. Kalirajan et alii (1996) utilizaram dados anuais de 28 províncias chinesas, o que garantia uma amostra muito maior do que a do presente trabalho.

Como não foi possível estimar a função fronteira partiu-se para a estimação de uma função determinista. De qualquer modo, remete-se o leitor mais interessado no assunto às revisões feitas por Forsund et alii (1980), Pinheiro (1989) e Conceição (1998 a), bem como aos artigos de Aigner et alii (1977), Jondrow et alii (1982) e Nishimizu e Page (1982).

\section{A Função de Produção Cobb-Douglas}

O primeiro problema que surge ao pesquisador que pretende estimar uma função de produção é a escolha da forma funcional adequada. No presente trabalho optou-se 
pela função de produção do tipo Cobb-Douglas essencialmente por duas razões. Como a série de dados disponível é relativamente curta, e como comparativamente a outros modelos a função apresenta um pequeno número de parâmetros a serem estimados, garante-se um maior número de graus de liberdade. A segunda razão é que essa é a forma funcional mais utilizada nos estudos de produtividade, o que permite uma análise comparativa mais rica. Desde o estudo de Solow, passando pelo clássico trabalho de Hayami e Ruttan (1988), até a maior parte dos estudos resenhados (Fulginiti e Perrin 1993 e 1998, Kalirajan et alii 1996, Lau e Yotopoulos 1989), fizeram uso da função Cobb-Douglas.

Em sua forma mais geral a função Cobb-Douglas pode ser expressa por $^{29}$

(5.10) $\quad \mathrm{Y}=A X_{1}^{{ }_{1}{ }_{1}} X_{2}{ }^{\alpha_{2}} \ldots X_{n}^{\alpha_{n}} \varepsilon=A \prod_{i=1}^{n} X_{i}^{\alpha_{i}} \mathcal{E}$

onde,

$\mathrm{Y}=$ produto

$X_{\mathrm{i}}=$ fatores de produção

$\mathrm{A}=$ constante positiva

$\alpha_{\mathrm{i}}=$ coefịcientes de elasticidades parciais da produção

$\varepsilon=$ erro aleatório multiplicativo cujo logaritmo tem distribuição normal com média zero e variância $\sigma^{2}$

As principais características da função Cobb-Douglas são:

1) $\mathrm{O}$ produto físico médio de um fator $\mathrm{X}_{\mathrm{i}}\left(\mathrm{PFMe}_{\mathrm{xi}}\right)$ qualquer é sempre positivo e decrescente conforme aumenta o uso de $\mathrm{X}_{\mathrm{i}}$. 
PFMex $x_{i}=\frac{Y}{X_{i}}=A X_{1}^{\alpha_{1}} \ldots X_{i}^{\alpha_{i}} \ldots X_{n}^{{ }^{\alpha_{n}}}=\alpha_{i}\left[\frac{\mathrm{Y}}{\mathrm{X}_{\mathrm{i}}}\right]$

2) $\mathrm{O}$ produto físico marginal de $\mathrm{X}_{\mathrm{i}}\left(\mathrm{PFMg}_{\mathrm{xi}}\right)$ é positivo se $\alpha_{\mathrm{i}}>0$ e decrescente conforme se aumenta o uso de $X_{i}$

$P F M g x_{i}=\frac{\partial Y}{\partial X_{i}}=\alpha_{i} A X_{1}^{\alpha_{1}} \ldots X_{i}^{\alpha_{i}-1} \ldots X_{n}^{\alpha_{n}}=\alpha_{i}\left[\frac{Y}{X_{i}}\right]>0$

3) A elasticidade de produção do fator $X_{i}\left(E_{x i}\right)$ é constante, ou seja, independe da combinação dos fatores e do produto.

$$
E x_{i}=\frac{\partial Y}{\partial X_{i}} \frac{X_{i}}{Y}=\left[\alpha_{i}\left(\frac{Y}{X_{i}}\right)\right] \frac{X_{i}}{Y}=\alpha_{i}
$$

4) O grau de retornos à escala, ou grau de homogeneidade, é dado pela soma dos coeficientes $\alpha_{i}$.

5) A taxa marginal de substituição entre dois fatores $X_{i}$ e $X_{j}\left(T M S_{\text {xixj }}\right)$ é dada por

$$
T M S_{x i x j}=\frac{\partial X_{i}}{\partial X_{j}}=\frac{f_{x i}}{f_{x j}}=\frac{\partial Y / \partial X_{i}}{\partial Y / \partial X_{j}}=\frac{\alpha_{j}}{\alpha_{i}} \frac{X_{i}}{X_{j}}
$$

${ }^{29}$ Uma boa apresentação da função Cobb-Douglas pode ser encontrada em Silva (1996) e Silberberg (1990). 
6) A elasticidade de substituição entre dois fatores $X_{i}$ e $X_{j}$ é constante e igual a 1. A elasticidade de substituição é dada pela relação entre as variações no uso dos insumos e pelas variações relativas das taxas marginais de substituição, ou seja,

$$
E s=\frac{\partial\left(X_{i} / X_{j}\right) /\left(X_{i} / X_{j}\right)}{\partial\left(f x_{j} / f x_{i}\right) /\left(f x_{j} / f x_{i}\right)}=\frac{\partial\left(X_{i} / X_{j}\right) \quad\left(\alpha_{j} / \alpha_{i}\right)\left(X_{i} / X_{j}\right)}{\partial\left[\left(\alpha_{j} / \alpha_{i}\right)\left(X_{i} / X_{j}\right)\right] \quad\left(X_{i} / X_{j}\right)}=1
$$

7) A função Cobb-Douglas é linear nos logaritmos.

$$
\ln Y=\ln A+\alpha_{1} \ln X_{1}+\ldots+\alpha_{n} \ln X_{n}+\ln \varepsilon
$$

O modelo econométrico a ser estimado terá a forma apresentada na equação (5.11). As variáveis explicativas a serem utilizadas são o estoque de tratores (medido em número e em cv), a mão-de-obra empregada (medida em equivalentes-homem), a área cultivada de lavouras temporárias e permanentes (em hectares), a quantidade consumida de fertilizantes (em toneladas de nutrientes) e o estoque de animais. A variável dependente será medida de duas formas alternativas, quais sejam, o valor da produção das lavouras (temporárias e permanentes) e o valor da produção total (lavouras e produtos de origem animal).

O intuito de estimar funções com essas duas especificações alternativas é o de tentar mensurar os efeitos da hipótese simplificadora em usar o estoque de tratores como aproximação do estoque de capital agregado. Ocorre que na produção de lavouras a maior parte do capital empregado encontra-se exatamente no estoque de tratores. $\mathrm{O}$ mesmo não acontece, entretanto, com a pecuária, principalmente a de pequenos animais. Nesse caso o peso de construções (galpões, fábricas de ração, salas de ordenha, etc) é apreciável e, portanto, a elasticidade estimada para o capital pode estar "contaminada" por informações não especificadas no modelo. Espera-se que a função de produção 
tendo o valor da produção de lavouras como variável dependente permita isolar a elasticidade da produção com relação aos tratores agrícolas.

A discussão a respeito das fontes de dados, bem como da forma como foram utilizados serão assunto da seção 5.3. Por ora, resta dizer que os principais objetivos perseguidos com a estimação da função de produção são responder a duas questões: são os retornos na produção constantes a escala? e, quais as participações relativas dos fatores no produto?

\subsection{3 - O método não-paramétrico de medida da produtividade}

O método não-paramétrico de medida da produtividade total dos fatores consiste na razão entre um índice de produto e um índice de insumos. De acordo com Selvanathan e Rao (1994) existe um número muito grande de índices conhecidos na literatura, embora apenas alguns deles apresentem as propriedades exigidas pela teoria ${ }^{30}$. Como salientam Silva e Carmo (1986) é fundamental que haja compatibilidade entre o índice selecionado e a análise econômica. Em especial, chamam atenção para a correlação existente entre a forma funcional admitida e o número índice selecionado.

A partir do trabalho de Diewert (1976) diz-se que um índice é exato quando ele representa perfeitamente uma dada forma funcional. Segundo Dias (1998), os índices geométricos são exatos para a função de produção Cobb-Douglas. De acordo com Selvanathan e Rao (1994) o formato geral de um índice geométrico seria dado por $^{31}$,

\footnotetext{
${ }^{30}$ A teoria dos números índices é bastante complexa e um aprofundamento da mesma escaparia aos propósitos desse trabalho. Silva e Carmo (1986) e Selvanathan e Rao (1994) fazem uma revisão dos trabalhos mais importantes sobre o assunto.

${ }^{31}$ Os autores afirmam que esse formato de índice vem sendo batizado na literatura de índice CobbDouglas (página 23).
} 


$$
\frac{P T F_{t}}{P T F_{t-1}}=\frac{\prod_{i=1}^{n}\left[\frac{Y_{i t}}{Y_{i t-1}}\right]^{W_{i}}}{\prod_{j=1}^{p}\left[\frac{X_{j t}}{X_{j t-1}}\right]^{m_{j}}}
$$

onde,

$$
\begin{aligned}
& \mathrm{Y}_{\mathrm{it}}=\text { quantidade dos } \mathrm{i} \text {-ésimo produto } \\
& \mathrm{X}_{\mathrm{it}}=\text { quantidade do i-ésimo insumo } \\
& \mathrm{w}_{\mathrm{it}}=\text { participação do produto i no valor do produto total } \\
& \mathrm{m}_{\mathrm{j}}=\text { participação do insumo } \mathrm{j} \text { no total dos insumos }
\end{aligned}
$$

A principal diferença entre os diferentes tipos de índices geométricos é a forma de cálculo das ponderações $\left(w_{i}\right.$ e $\left.m_{j}\right)$. Admitindo-se na expressão (5.12) que

$$
W_{i}=\frac{\left(W_{i t}+W_{i t}-1\right)}{2} \text { e } m_{i}=\frac{\left(m_{i t}+m_{i t}-i\right)}{2}
$$

chega-se ao îndice conhecido pelo nome de Tornquist. Esse índice, desde que foi recomendado por Christensen (1975), vem sendo amplamente utilizado em pesquisas de mensuração da PTF na agricultura. No Brasil, por exemplo, Gasques e Conceição (1998), Dias e Bacha (1998) e Arnade (1992a) fizeram uso dessa formulação para cômputo da produtividade.

Embora Diewert (1976) tenha demonstrado que o índice de Tornquist é exato com relação a função translog, Christensen (1975) afirma que, em realidade, a função translog fornece uma aproximação de segunda ordem a qualquer função homogênea 
duplamente diferenciável. Assim, seus resultados não divergem muito em diferentes especificações funcionais.

Uma vantagem de se usar um índice geométrico é que, como pode ser percebido através da equação (5.12), as ponderações são móveis ao longo do período. Essa característica faz com que o índice consiga captar as flutuações nos preços dos produtos e dos fatores, o que é especialmente importante nos mercados agrícolas, nos quais o ajuste no curto prazo se dá através de fortes variações nos preços.

Por essas razões, optou-se pelo uso do índice de Tornquist para servir como base de comparação com os resultados obtidos pelo método da contabilidade. É importante, entretanto, que se visualize a forte correlação entre os dois métodos. Substituindo a expressão (5.13) em (5.12) e tomando-se o logaritmo neperiano da mesma, chega-se a

$$
\ln \left(\mathrm{PTF}_{\mathrm{t}} / P T F_{t-1}\right)=\frac{1}{2} \sum_{i=1}^{n}\left(w_{i t}+w_{i t-1}\right) \ln \left[\frac{Y_{i t}}{Y_{i t}-1}\right]-\frac{1}{2} \sum_{j=1}^{p}\left(m_{i t}+m_{i t}-1\right) \ln \left[\frac{X_{j t}}{X_{j t}-1}\right]
$$

que é a formulação geral de Tornquist utilizada para os cálculos deste estudo.

Se agora na equação fundamental do crescimento (equação 5.9) substituir-se $\mathrm{W}_{\mathrm{K}}$ e $\mathrm{W}_{\mathrm{L}}$ respectivamente por $1 / 2\left(\mathrm{~W}_{\mathrm{Kt}}-\mathrm{W}_{\mathrm{Kt}-1}\right)$ e $1 / 2\left(\mathrm{~W}_{\mathrm{Lt}}-\mathrm{W}_{\mathrm{Lt}-1}\right)$ e notando que em tempo discreto

$$
\text { (5.15) } \quad \frac{\dot{\mathrm{Y}}}{\mathrm{Y}}=\ln Y_{t}-\ln Y_{t-1}
$$

é possível reescrever (5.9) como 


$$
\ln \left[\frac{\mathrm{A}_{t}}{\mathrm{~A}_{t-1}}\right]=\ln \left[\frac{Y_{t}}{Y_{t-1}}\right]-\frac{1}{2}\left(W_{k t}+W_{K t-1}\right) \ln \left[\frac{K_{t}}{K_{t-1}}\right]-\frac{1}{2}\left(W_{L t}+W_{L t-1}\right) \ln \left[\frac{L_{t}}{L_{t-1}}\right]
$$

Note-se que a expressão (5.16) guarda correlação direta com (5.9). Na verdade, são a mesma coisa.

\section{3 - Os dados}

Os dados utilizados no trabalho são provenientes de diversas fontes. A seguir, elas são descritas e detalhados os procedimentos que caracterizam as séries a serem utilizadas.

\section{Produto}

A base de dados utilizada para dar conta da produção de lavouras foi a Produção Agrícola Municipal (PAM), publicada anualmente pelo IBGE. Foram computadas as lavouras temporárias e permanentes, perfazendo um total de 55 culturas. Essas séries são publicadas tanto em valor quanto em quantidade, o que permite calcular o preço adotado pelo IBGE para cada produto.

Os valores são nominais, tendo como período base o mês de dezembro. As quantidades são medidas das mais diversas formas (cachos, mil frutos, toneladas, etc.) o que impede a soma direta de todos os produtos. Por essa razão são adotados os preços de 1995 como padrão, construindo um índice de produção com base nesses preços.

As informações relativas à produção pecuária vieram também do IBGE, através da Produção da Pecuária Municipal (PPM). Dentre os dados publicados pela pesquisa 
foram selecionadas a produção de carne de frango e de suíno, a produção de leite, de lã, de ovos de galinha e de codorna e de mel. Dos principais produtos da pecuária o único excluído foi a produção de carcaça bovina. Por ser um produto importante em volume, essa exceção requer justificativa. Ocorre que não existe nenhuma série anual que dê conta da área de pastagem no país; apenas os dados dos Censos Agropecuários contém essa informação. Por essa razão julgou-se que seria equivocado acrescentar à produção o volume de bovinos abatidos sem utilizar como contrapartida o principal insumo consumido pela pecuária de corte.

Dentre os produtos animais, apenas aves e suínos não apresentam o valor anual da produção. Assim, foram utilizados os preços de frangos e suínos no atacado divulgados pelo Instituto de Economia Agrícola (IEA). Adotou-se o preço de dezembro de cada ano como base, a fim de apresentar o mesmo período base que os demais dados divulgados pelo IBGE.

\section{Estoque de Animais}

Para medir a produtividade na pecuária é necessário considerar como insumo de produção o estoque de animais ${ }^{32}$. Para tanto fez-se uso das informações de estoque de animais divulgadas pela PPM. Ocorre que o valor do estoque só foi divulgado até o ano de 1988, o que impedia seu uso no cálculo do índice de Tornquist.

O procedimento adotado para solucionar o problema consistiu em dividir (no período de 1975 a 1988) o valor do rebanho de suínos e de aves pelas respectivas quantidades. Assim são obtidos os preços médios de cada animal. Dividindo esses valores pelo preço pago por quilo ao produtor do suíno para abate tipo carne, e pelo preço do quilo do frango para corte (IEA) no mês de dezembro, chegou-se ao peso médio por animal. Adotou-se, a partir de então, o peso médio por animal do período,

\footnotetext{
${ }^{32}$ A base da medida de produtividade na pecuária é o desfrute, definido como o número de cabeças abatidas sobre o total do rebanho.
} 
multiplicando-o pelo número de cabeças e pelo preço do quilo de suínos e de aves. No caso das vacas leiteiras adotou-se o preço da vaca de leite de 5 litros (IEA).

A inclusão do estoque de animais no denominador do índice de Tornquist causa alterações nos resultados, como será visto adiante. Acredita-se que uma parte da divergência dos resultados dos diferentes trabalhos que fazem uso do índice de Tornquist deve-se, em alguma medida, a essa diferença.

\section{Área Cultivada}

Foram utilizadas as informações de área/colhida das lavouras temporárias e permanentes fornecidas pela PAM do IBGE. / Para o cálculo das participações dos fatores no índice de Tornquist fez-se uso dos preços de arrendamento de terras para lavouras para o Brasil, divulgados pela Fundação Getúlio Vargas.

\section{Fertilizantes}

O consumo aparente de fertilizantes foi coletado em duas fontes distintas. De 1973 a 1986 os dados são do IBGE. A partir de 1986 os anuários da ANDA serviram de base. Adotou'-se o consumo de fertilizantes em nutrientes totais, uma vez que dessa forma seria possível captar alterações nas concentrações dos adubos (uma importante mudança qualitativa do insumo). Calculou-se o preço da tonelada do nutriente a partir dos preços do mês de dezembro do sulfato de amônio ( $20 \%$ de $\mathrm{N}$ ), do superfosfato simples ( $18 \%$ de $\mathrm{P}_{2} \mathrm{O}_{5}$ ) e do cloreto de potássio $\left(60 \%\right.$ de $\mathrm{K}_{2} \mathrm{O}$ ). A fonte de dados dos preços foi novamente o IEA. 


\section{Mão-de-Obra}

A série de mão-de-obra é aquela que apresenta os maiores problemas de construção. A única fonte sistemática de informação é a Pesquisa Nacional por Amostras de Domicílios (PNAD), realizada pelo IBGE, que publica dados de pessoal ocupado por ramo de atividade. Ocorre que, como apontam Gasques e Conceição (1998), houve uma mudança no método de cálculo do pessoal ocupado a partir de 1992. De acordo com os autores, a partir deste ano foram computadas todas as pessoas que se localizavam na agricultura, ainda que não exercessem algum trabalho agrícola, como aqueles ocupados na produção para auto-consumo, os que trabalhavam em construção para uso próprio e aqueles não-remunerados que trabalhavam menos de 14 horas. Este fato levaria a uma elevação súbita no pessoal ocupado após 1992. Para corrigir esse desvio Gasques e Conceição (1998) fazem uso de uma tabulação especial cedida pelo IBGE, que garante a compatibilização das informações entre os anos da série. Por essa razão utilizou-se, no presente trabalho, a série de Gasques e Conceição ${ }^{33}$.

Entretanto, duas diferenças de procedimento foram adotadas com relação ao referido trabalho. Uma primeira modificação foi transformar a série de pessoal ocupado em equivalentes - homem $(\mathrm{EH})$, seguindo procedimento recomendado por Silva e Kageyama (1983) e utilizado em diversos estudos (Dias 1998, Silva 1996). O procedimento consiste em atribuir ponderações às diferentes categorias de trabalhadores. Com base nos dados dos Censos Agropecuários de 1970, 1975, 1980 e 1985, os

33 O autor gostaria de agradecer a gentileza de Gasques e Conceição pela disponibilização da série de pessoal ocupado. Teria sido impossível corrigir os desvios causados pela alteração metodológica do IBGE, o que reduziria a qualidade dos resultados do estudo. 
trabalhadores são classificados em 3 categorias: homens maiores de 14 anos; mulheres maiores de 14 anos e; crianças com menos de 14 anos. Os pesos atribuídos a cada grupo foram, respectivamente, 1, 0,6 e 0,5. Os resultados encontrados são idênticos aos de Silva e Kageyama (1983), embora esses façam um maior número de divisões dos grupos de trabalhadores (parceiros, responsável e membros não remunerados da família, trabalhadores assalariados). A tabela 10 apresenta os resultados. Nela, encontra-se o número de trabalhadores do sexo masculino e feminino com mais do que 14 anos e o número total de crianças. Comparando-se o número total de pessoas ocupadas com o número total de equivalentes - homem, nota-se que o valor em EH variou em $78 \%$ e 82 $\%$. Com base nesses resultados adotou-se um valor médio equivalente de $80 \%$.

Tabela 10 - Pessoal Ocupado e Equivalentes-Homem nos Censos Agropecuários de 1970, 1975, 1980, 1985 e 1995 (em número total de pessoas)

\begin{tabular}{lccccc}
\hline \multicolumn{1}{c}{ CATEGORIAS } & $\mathbf{1 9 7 0}$ & $\mathbf{1 9 7 5}$ & $\mathbf{1 9 8 0}$ & $\mathbf{1 9 8 5}$ & $\mathbf{1 9 9 5}$ \\
\hline HOMENS > 14 anos & 10.125 .057 & 10.399 .289 & 12.030 .455 & 12.954 .379 & 10.586 .363 \\
MULHERES $>\mathbf{1 4}$ anos & 4.556 .702 & 5.556 .189 & 5.393 .097 & 6.176 .906 & 4.908 .909 \\
CRIANÇAS < 14 anos & 2.900 .330 & 4.390 .214 & 3.740 .183 & 4.263 .634 & 2.435 .678 \\
PESSOAL TOTAL (PT) & 17.582 .089 & 20.345 .692 & 21.163 .735 & 23.394 .919 & 17.930 .950 \\
EQUIVALENTES-HOMEM (EH) & 14.309 .243 & 15.928 .109 & 17.136 .405 & 18.792 .340 & 14.749 .547 \\
\hline EH / PT (\%) & $\mathbf{8 1 \%}$ & $-\mathbf{7 8 \%}$ & $\mathbf{8 1 \%}$ & $\mathbf{8 0 \%}$ & $\mathbf{8 2 \%}$ \\
\hline
\end{tabular}

Fonte: IBGE e cálculos do autor

No que concerne à remuneração ao trabalho, adotou-se o preço do salário do trabalhador mensalista publicado pela FGV. O salário do Brasil foi obtido através de uma média ponderada entre o salário em cada região do país, multiplicado pela proporção de trabalhadores em cada região. Os Censos Agropecuários de 1985 e 1995 serviram de base para medir a distribuição do pessoal ocupado nas diferentes regiões do Brasil. O uso do salário como medida do valor dos serviços do trabalho é um diferencial com relação ao trabalho de Gasques e Conceição (1998), uma vez que esses autores fizeram uso do ponto médio de cada classe de rendimento fornecido na PNAD. 
Duas observações merecem consideração. Em primeiro lugar é provável que ao multiplicar o valor do salário em um mês pelo número total de pessoas ocupadas, o peso relativo do fator trabalho se torne um tanto elevado. Ocorre que se consideram pessoas ocupadas aquelas que exercem por certo período da semana um mínimo de horas trabalhadas. Se, por exemplo, uma pessoa trabalha meio período na propriedade rural e meio período estuda, ela é computada como fazendo parte da estatística de pessoal ocupado. Assim, como é impossível determinar precisamente qual o número total de horas efetivamente trabalhadas em um mês, ao se atribuir um salário de mensalista a todos os trabalhadores da pesquisa, estar-se-á exagerando o valor total dos serviços da mão-de-obra.

Outro ponto a ser destacado é que não foi feita nenhuma correção para a elevação do nível de qualificação da mão-de-obra. No caso do Índice de Tornquist esse aspecto é em parte captado pelas variações nos preços, como argumentam Gasques e Conceição (1998), uma vez que o índice considera os preços correntes no cálculo das participações dos fatores. Logo, mudanças na qualidade do fator seriam captadas pelos preços.

\section{O estoque de capital}

A estimação do estoque de capital foi devidamente explicada no capítulo anterior. Entretanto, algumas considerações devem ser feitas quanto ao valor do serviço do capital. ,

Griliches (1960, 1963) e Griliches e Jorgenson (1966) são enfáticos em afirmar que o serviço do capital deveria ser medido através do seu valor de aluguel. $\mathrm{O}$ ideal seria, na opinião dos autores, multiplicar o número de horas trabalhadas pelo valor de uma hora de serviço da máquina. Num mercado competitivo, o valor do aluguel refletiria perfeitamente as oscilações de mercado, indicando qual seria a produtividade marginal do capital.

De fato, o valor de aluguel do equipamento seria a melhor informação possível para avaliar o valor do serviço de um trator. Ocorre que não foi possível encontrar 
nenhuma série de preços de aluguel de tratores. Essa ausência de informação força a adoção de medidas alternativas. Alguns autores fazem uso do valor do estoque como aproximação do valor do serviço. Griliches (1960) comenta que essa opção não seria muito conveniente uma vez que o valor do estoque representa a soma do valor do volume de serviços correntes e do valor descontado dos serviços futuros. Como o que interessa medir a cada ano é o valor do serviço naquele ano, o uso do valor do estoque como proxy do valor dos serviços inflaria os resultados.

Um procedimento utilizado em pesquisas é aproximar o valor dos serviços pela multiplicação dos juros de mercado pelo valor do estoque. Mais uma vez, Griliches (1963b) alerta para os riscos dessa opção. Em particular, o autor demonstra que a escolha de diferentes taxas de juros afetam significativamente os resultados. Comenta, também, que o juro de interesse seria aquele que o proprietário do trator usa para avaliar o retorno de sua atividade. Na verdade, o autor recomenda que se utilize a produtividade marginal do capital como melhor forma de aproximação da taxa considerada pelo agente econômico. Griliches (1963), ainda, citando estudos de funções de produção na agricultura norte-americana, afirma que a produtividade margina das máquinas agrícolas situava-se entre $20 \%$ e $25 \%$, sendo $15 \%$ seu limite inferior. Note-se portanto, que caso o juro básico de mercado americano fosse tomado como base para o cálculo do valor do serviço, os resultados seriam certamente viesados.

Em deøorrência dessas considerações optou-se por testar, no caso do índice de Tornquist, três alternativas de mensuração dos serviços do capital, o que permitiu avaliar os impactos de cada uma delas no cálculo da produtividade total dos fatores. A primeira alternativa consistiu em usar o valor do estoque calculado no capítulo 4. Na segunda, fez-se uso do coeficiente estimado na função de produção Cobb-Douglas para calcular o valor do produto físico marginal dos tratores. A terceira forma adotada consistiu em utilizar o valor do trator no último ano de vida, descontado de seu valor de sucata (admitido como 10\%), acrescido dos gastos anuais com manutenção (adotada como equivalente à taxa de depreciação) e com combustível (calculado a partir dos dados do Censo Agropecuário de 1985). Essa última forma serviu mais para testar a sensibilidade 
dos resultados às diferentes formas de cálculo dos serviços do capital. $\mathrm{Na}$ seção referente aos resultados do índice de Tornquist esse procedimento será discutido em maiores detalhes.

\section{4 - Os resultados}

\section{Da Função de Produção}

A função de produção Cobb-Douglas foi estimada tendo como variável dependente duas versões alternativas. Na primeira, considerou-se apenas o valor da produção agrícola das lavouras (VA); na segunda, tomou-se o valor total da produção agropecuária (VT). As variáveis explicativas especificadas foram: i) estoque de tratores, medido em unidade (UN) e em potência (CV); ii) mão-de-obra, em número de equivalentes-homem (MO); iii) área cultivada em hectares (HA); iv) fertilizantes, em toneladas de nutrientes (FE); v) rebanho, considerado em valor (RE). A única variável explicativa que não foi medida em quantidade foi, portanto, o rebanho de animais. Ocorre que a ampla diversidade de espécies de animais impede que se faça uma soma do número total de cabeças do rebanho. Para somar número de cabeças de aves com número total de vacas leiteiras, haveria que se estabelecer um peso relativo para cada categoria animal. Como estabelecer essa ponderação é sempre uma questão com certo grau de aleatoriedade, preferiu-se adotar os preços relativos como parâmetro de agregação. As. demais variáveis independentes, entretanto, foram todas medidas em quantidade, de acordo com a tradição dos diferentes estudos de função de produção resenhados.

O maior problema encontrado na estimação da função de produção foi o da multicolinearidade. Com exceção da mão-de-obra, todas as variáveis explicativas apresentam correlações relativamente elevadas. O quadro 1 sintetiza as correlações 
simples entre as variáveis independentes. Note-se que as correlações entre fertilizantes, capital e área, e entre o rebanho e as demais são especialmente altas. Existe também uma correlação forte entre a área e as duas medidas de capital, como era de se esperar.

\begin{tabular}{|c|cccc|c|c|}
\hline & UN & CV & MO & HA & FE & RE \\
\hline UN & 1,00 & 1,00 & $-0,27$ & 0,87 & 0,90 & 0,88 \\
CV & & 1,00 & $-0,27$ & 0,86 & 0,90 & 0,88 \\
MO & & & 1,00 & $-0,20$ & $-0,14$ & $-0,29$ \\
HA & & & & 1,00 & 0,82 & 0,65 \\
FE & & & & & 1,00 & 0,81 \\
RE & & & & & & 1,00 \\
\hline
\end{tabular}

\section{Quadro 1 - Coeficientes de Correlação Simples entre as Variáveis Explicativas}

Para tentar contornar o problema, procurou-se seguir as recomendações de Koutsoyannis (1977) e de Mukherjee et alii (1998). Muito embora esses autores afirmem que os problemas de multicolinearidade sejam, no mais das vezes, de difícil solução, recomendam que seja feito um teste de sensibilidade da importância relativa de cada variável na explicação da variável dependente. Koutsoyannis recomenda que se deve fazer uma sequência progressiva de regressões, iniciando por aquela variável que o pesquisador julga ser a mais relevante; a partir do resultado desta regressão, acrescentam-se, uma a uma, as demais variáveis. A cada inclusão avalia-se o efeito causado no coeficiente de determinação, bem como o nível de significância do coeficiente estimado da variável acrescentada. Caso a variável adicionada não tenha melhorado o poder de explicação e/ou tenha apresentado sinal contraditório com a teoria, ela é passível de ser excluída da análise.

Mukherjee et alii (1998) recomendam um procedimento alternativo para medir o grau relativo de importância de uma variável. Os autores afirmam que uma forma de dimensionar a importância da variável seria medir a estabilidade dos coeficientes nas diferentẹ regressões. Fazendo todas as combinações possíveis entre as variáveis 
explicativas, é possível estabelecer qual a variação dos coeficientes estimados. Aquelas variáveis que apresentarem a menor variação (portanto maior estabilidade), seriam as mais importantes. De qualquer maneira, assinalam que nem por isso deve-se abandonar uma variável que pode ser relevante à análise; apenas afirmam que o procedimento serviria para medir a importância relativa da variável.

Os dois procedimentos recomendados foram adotados. As regressões foram progressivamente sendo estimadas medindo o impacto da variável acrescentada a cada regressão. Foram estimadas, também, todas as combinações possíveis entre as variáveis, avaliando-se as variações dos resultados. Desde logo, percebeu-se que a inclusão das variáveis fertilizantes e rebanho não melhoravam em nada as estimativas, além de apresentarem significância muito baixa dos parâmetros estimados. A variável rebanho, por exemplo, mostrou-se sistematicamente com sinal negativo. Por essas razões nos modelos selecionados optou-se pela exclusão dessas duas variáveis (FE e RE).

Os modelos selecionados encontram-se condensados no quadro 2. As variáveis explicativas são o capital (UN e CV), o trabalho (MO) e a área cultivada (HA). É possível perceber que a variável mais significativa foi o capital, seguido do trabalho. Percebe-se, ainda, que o coeficiente estimado relativo à área cultivada apresenta baixa significância. Em todos os modelos apresentados não foi possível rejeitar a hipótese de ausência de autocorrelação nos resíduos, ao nível de $1 \%$ de significância. Adicionalmente, note-se que os coeficientes de determinação são relativamente altos. 


\begin{tabular}{|c|ccccccc|}
\hline & UN & CV & HA & MO & $\mathbf{R}^{2}$ & $\underline{\mathbf{F}}$ & DW \\
\hline VA & $\mathbf{0 , 2 9 9 5 * *}$ & & $\mathbf{0 , 4 6 5 2}$ & $\mathbf{0 , 4 4 8 2}$ & 0,83 & $31,05^{* *}$ & $1,89^{* *}$ \\
& $(3,64)$ & & $(1,39)$ & $(1,54)$ & & & \\
\hline VA & & $\mathbf{0 , 2 7 1 7 ^ { * * }}$ & $\mathbf{0 , 4 6 4}$ & $\mathbf{0 , 4 4 8}$ & 0,83 & $31,46^{* *}$ & $1,90^{* *}$ \\
& & $(3,69)$ & $(1,41)$ & $(1,54)$ & & & \\
\hline VT & $\mathbf{0 , 4 5 7 0 ^ { * * }}$ & & $\mathbf{0 , 1 9 0 6}$ & $\mathbf{0 , 4 0 6 8}$ & 0,91 & $64,43^{* *}$ & $1,86^{* *}$ \\
& $(6,42)$ & & $(0,66)$ & $(1,61)$ & & & \\
\hline VT & & $\mathbf{0 , 4 1 3 5 * *}$ & $\mathbf{0 , 1 9 2 5}$ & $\mathbf{0 , 4 0 5 1}$ & 0,91 & $66,16^{* *}$ & $1,88^{* *}$ \\
& & $(6,54)$ & $(0,68)$ & $(1,63)$ & & & \\
\hline
\end{tabular}

\section{Quadro 2 - Funções de Produção Estimadas}

Observação: Os números entre parenteses indicam os valores do teste t.

** indica significância ao nível de $1 \%$

Vale observar a mudança nos valores dos parâmetros estimados quando a variável dependente é alterada. Percebe-se que o coeficiente da área cai pela metade, enquanto o do capital aumenta relativamente conforme é acrescentado ao valor da produção agrícola, o valor do produto de origem animal. Esse resultado era, em alguma medida, esperado, uma vez que na produção animal intensiva a área tem um peso muito menor na estrutura de custos de produção. Entretanto, o inverso ocorreu no caso do capital: a participação desse fator no produto é mais elevada na produção animal. A elevação no valor do coeficiente do capital pode estar refletindo a ausência de componentes do estoque de capital não especificados no presente trabalho. Os coeficientes do capital nas funções de produção de lavouras devem refletir a importância das máquinas agrícolas na produção, uma vez que estas constituem a maior parte do capital nesse segmento da agricultura.

Nos modelos selecionados, tomou-se a preocupação adicional de realizar testes para tentar captar a presença de heterocedasticia. Embora, segundo Mukherjee et alli (1998), nenhum teste de heterocedasticidade seja perfeito, eles constituem uma indicação do comportamento do resíduo. No presente trabalho fez-se uso do teste de 
White, não sendo possível rejeitar a hipótese de homocedasticidade em todos os modelos. Na verdade, como as estimativas foram feitas nos logaritmos das séries, era de se esperar que os resíduos apresentassem variância constante.

Ponto importante a ser testado no estudo de funções de produção Cobb-Douglas, e especialmente relevante para os propósitos do cômputo da produtividade total dos fatores, é o grau de retornos à escala na produção. Embora a soma dos coeficientes indique o grau de retornos à escala, é preciso testar se o resultado é estatisticamente diferente de 1. Utilizou-se o teste de Wald de restrição aos parâmetros tendo como hipótese nula que a soma dos parâmetros é igual a 1. Em todas as funções não foi possível rejeitar a hipótese de retornos constantes à escala.

As equações para o valor total da produção indicam que o componente capital participa com $40 \%$ do total produzido, o trabalho com outros $40 \%$ e a área cultivada com $20 \%$. Esses pesos serão utilizados na contabilidade do crescimento feitá mais adiante. Antes de passar aos resultados alcançados, requer-se apresentar a análise desenvolvida quanto a não-estacionariedade das séries.

\section{O Problema da Não-estacionariedade das Séries}

Com o,desenvolvimento da teoria econométrica das séries de tempo passou-se a perceber que a não-estacionariedade das séries econômicas comprometia os resultados das técnicas convencionais de regressão. Em especial, dois problemas levantados na literatura concernentes aos riscos de se trabalhar com a econometria convencional no tratamento de séries não-estacionárias se destacam, quais sejam: i) risco de estabelecer correlações espúrias entre as variáveis (vide a respeito Granger e Newbold, 1974); e, ii) risco das variáveis se distanciarem no longo prazo, impossibilitando o estabelecimento de uma correta correlação entre elas (Dickey et alii 1994). 
De acordo com Dickey et alii (1994), os parâmetros estimados pelo método de mínimos quadrados ordinários só são válidos se as variáveis forem cointegradas, ou seja, se existir uma relação estável no longo prazo entre as mesmas. Um conjunto de séries será cointegrado se existir uma combinação linear (um vetor) entre as séries que faça com que o resíduo dessa integração seja estacionário. Se este vetor existir significa que as variáveis mantém uma relação estável no longo prazo e, dessa maneira, os resultados da regressão linear tornam-se válidos. O problema a ser resolvido, portanto, é determinar se as séries utilizadas na função de produção são cointegradas.

O primeiro passo foi o estabelecimento da ordem de integração das séries. Seguindo orientação de Hamilton (1994, capítulo 15), realizou-se um teste de raiz unitária nos logaritmos das séries (forma usada na função de produção estimada). $\mathrm{O}$ procedimento adotado seguiu a sequência recomendada por Enders (1995). Partiu-se do modelo mais completo, com constante e tendência determinista. Como não foi rejeitada a presença de raiz unitária nessa formulação e o coeficiente da variável tendência mostrou-se não significativo, testou-se o modelo apenas com a constante. Como, novamente, não houve rejeição da hipótese nula e a constante apresentou-se não significativa, avaliou-se o modelo sem constante e sem tendência. Dada a não rejeição da hipótese nula, foi possível concluir que as séries não eram estacionáriás, partindo-se, então, para o teste nas diferenças das mesmas: Testou-se, então, se a diferença da série continha raiz unitária; em caso de rejeição da hipótese nula, dir-se-ia que a variável é integrada de primeira ordem.

Os testes de raiz unitária seguiram o método de Dickey e Fuller aumentado. Os resultados dos testes estão resumidos no quadro 3. Nele, encontram-se elencadas todas as séries, bem como os resultados da sequência dos testes realizados. As letras $\mathbf{n}$ e d indicam, respectivamente, as séries em nível e nas primeiras diferenças. No rodapé da tabela apresenta-se os valores críticos para o nível de $1 \%$ de significância. Os resultados presentes na tabela foram selecionados utilizando-se o Critério de Akaike para definição do número de defasagens. É possível notar que todas as séries são integradas de primeira ordem $(\mathrm{I}(1))$. 


\begin{tabular}{|c|c|c|c|c|}
\hline VARIAVEIS & DIFERENÇAS & $\tau_{\tau}$ & $\tau_{\boldsymbol{u}}$ & $\tau$ \\
\hline $\mathbf{V A}$ & $\mathbf{N}$ & $-1,600$ & $-1,518$ & $-1,495$ \\
& $\mathbf{D}$ & & & $-4,257$ \\
$\mathbf{V T}$ & $\mathbf{N}$ & $-1,830$ & $-1,811$ & $-2,300$ \\
& $\mathbf{D}$ & & & $-3,728$ \\
$\mathbf{U N}$ & $\mathbf{N}$ & $-2,481$ & $-3,088$ & $-0,158$ \\
& $\mathbf{D}$ & & & $-2,982$ \\
$\mathbf{C V}$ & $\mathbf{N}$ & $-2,593$ & $-3,069$ & $-0,119$ \\
& $\mathbf{D}$ & & & $-3,248$ \\
$\mathbf{H A ́}$ & $\mathbf{N}$ & $-1,992$ & $-2,652$ & $-1,103$ \\
& $\mathbf{D}$ & & & $-3,284$ \\
$\mathbf{M O}$ & $\mathbf{N}$ & $-2,889$ & $-3,033$ & $-0,144$ \\
& $\mathbf{D}$ & & & $-5,056$ \\
\hline
\end{tabular}

Quadro 3 - Testes de Raiz Unitária para as Séries de Valor da Produção, Estoque de Capital, Mão-de-obra e Área

Observações: $\mathrm{n}=$ variável em nível; $\mathrm{d}$ = variável na primeira diferença.

Os valores críticos ao nível de significância de $1 \%$ são:

$\tau_{\tau}=-4,38 ; \tau_{\mu}=-3,75 ; \tau=-2,66$

Uma vez determinado que todas as séries são integradas de primeira ordem realizou-se o teste de cointegração pelo método de Johansen. O modelo estimado foi com constante irrestrita, adotando-se como critério de seleção do número de defasagens a minimização do valor Akaike. O quadro 4 resume os testes de cointegração efetuados para as quatro funções de produção estimadas. Os valores apresentados referem-se à estatística $\lambda_{\text {traço }}$. É possível notar que, em todas as quatro estimativas, rejeita-se, ao nível de $99 \%$ de probabilidade, a hipótese nula de ausência de um vetor de cointegração, em detrimento a hipótese de existência de um vetor de cointegração. 


\begin{tabular}{|c|c|c|c|c|c|c|c|}
\hline $\begin{array}{c}\text { Número de Vetores de } \\
\text { Cointegração }\end{array}$ & \multicolumn{2}{|c|}{ VA } & \multicolumn{2}{c|}{ VT } & \multicolumn{2}{c|}{ Valores Críticos } \\
\hline $\mathbf{H}_{\mathbf{0}}$ & $\mathbf{H}_{\mathrm{a}}$ & UN & CV & UN & CV & $\mathbf{5 \%}$ & $\mathbf{1 \%}$ \\
\hline $\mathrm{r}=0$ & $\mathrm{r}=1$ & $58,365^{* *}$ & $60,893^{* *}$ & $57,57 * *$ & $59,614^{* *}$ & 47,21 & 54,46 \\
$\mathrm{r}<1$ & $\mathrm{r}=2$ & 28,487 & 29,353 & 29,322 & $29,757^{*}$ & 29,68 & 35,65 \\
$\mathrm{r}<2$ & $\mathrm{r}=3$ & $16,040^{*}$ & $16,597^{*}$ & $18,237 *$ & $17,765^{*}$ & 15,41 & 20,04 \\
$\mathrm{r}<3$ & $\mathrm{r}=4$ & $6,262^{*}$ & $6,372^{*}$ & $8,173^{*}$ & $8,291^{*}$ & 3,76 & 6,65 \\
\hline
\end{tabular}

Quadro 4 - Teste de Cointegração para as Séries Presentes nas Diferentes Funções de Produção Estimadas (estatística $\lambda_{\text {traço }}$ )

** significativo ao nível de $1 \%$

* significativo ao nível de 5\%

Como as variáveis nas quatro funções de produção são cointegradas, é possível afirmar que existe uma correlação estável entre as séries no longo prazo e, adicionalmente, garante-se que os parâmetros estimados são válidos.

\section{Medindo os Impactos das Diferentes Medidas do Capital no Cálculo da PTF: O Método da Contabilidade}

As funções de produção não permitiram estabelecer qual a importância relativa do rebanho e dos fertilizantes no produto total. Foi possível, entretanto, estabelecer que as participações do capital, do trabalho e da área no produto agropecuário são respectivamente, $40 \%, 40 \%$ e $20 \%$. Essas ponderações servirão de base para o primeiro exercício de contabilidade a ser desenvolvido. Uma das vantagens do método da contabilidade é que ele não é tão sensível a variações nas ponderações adotadas, como ressaltam Bonelli e Fonseca (1998). Dentro de certa margem de alteração dos pesos dos 
fatores, os impactos sobre o valor da PTF são relativamente pequenos, como será visto adiante.

A fim de dar conta dos fertilizantes, dividiu-se o peso do capital entre máquinas e fertilizantes, cabendo ao primeiro o peso de $30 \%$ e ao segundo, $10 \%$. O quadro 5 , inspirado em Bonelli e Fonseca (1998), apresenta o esquema da contabilidade do crescimento. No lado esquerdo do quadro encontram-se apresentadas as séries de valor da produção agropecuária, da área cultivada, do estoque de capital em unidades, dos fertilizantes e da mão-de-obra. É possível perceber que o produto aumentou em $90 \%$ no período, o que representa um crescimento de $3,26 \%$ ao ano. A área cultivada mostrou uma pequena elevação entre os anos de 1975 e 1995, com um aumento equivalente a 17\%. O número de tratores mais do que dobrou, elevando-se em 140\%. Pode-se perceber, também, o expressivo aumento do consumo de fertilizantes, medido em toneladas de nutrientes; o consumo total triplicou entre 1975 e 1995. Por fim, vale notar que o pessoal ocupado não mudou em nada nos 20 anos em questão.

A parte central do quadro apresenta as taxas anuais de crescimento do produto e dos diferentes fatores de produção. Aparecem, também, as variações na produtividade total do fatores. Chama atenção as fortes oscilações anuais das taxas de crescimento, o que é uma característica típica da agricultura. Do lado direito do quadro, visualizam-se as produtividades parciais e total dos fatores. Pode-se perceber que houve no período um aumento considerável da produtividade da terra, equivalente a $63 \%$ em 20 anos. Esse crescimento corresponde a uma taxa composta anual de 2,47\%. Note-se, adicionalmente, que os índices de produtividade do capital em unidades e dos fertilizantes foram decrescentes no período. A produtividade do trabalho cresceu a taxas elevadas, atingindo $3,26 \%$ ao ano. Pode-se perceber que com essa estrutura de ponderação, e com o estoque de capital sendo medido em número de tratores, a PTF elevou-se $20 \%$ no período. Outro ponto a ser percebido é que foi somente a partir de meados dos anos 80 que passou a haver uma elevação mais expressiva na PTF. 


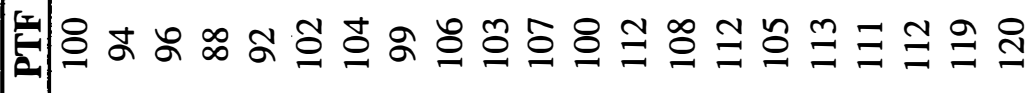

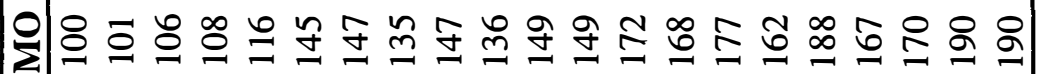

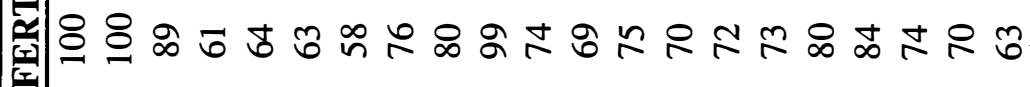

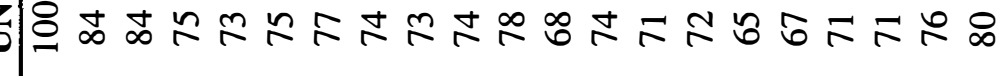

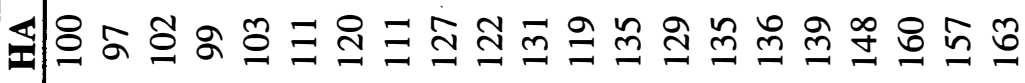

ลุ ㅇำ

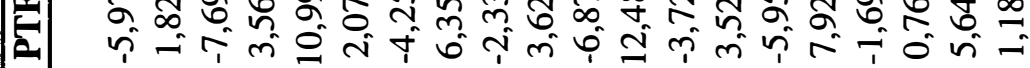

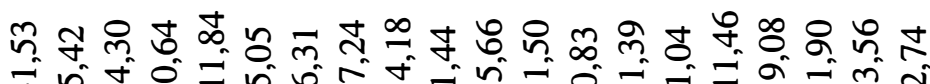

जी जी

ㅇํ ○ก่

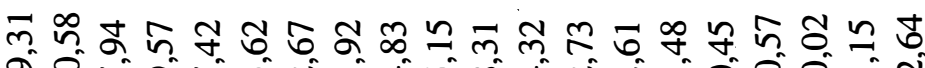

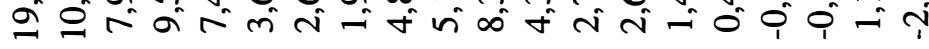
廿 ㅇำ ती

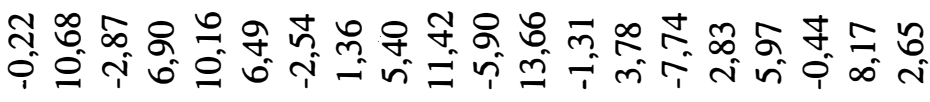

잉ㅇㅇ ๙

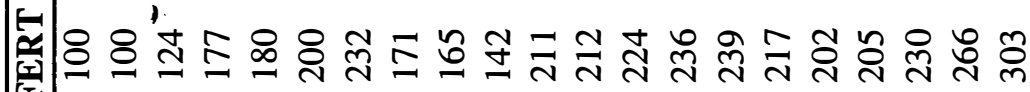

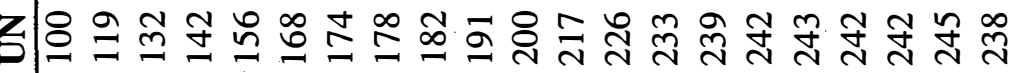

$\llbracket 8$ ๖

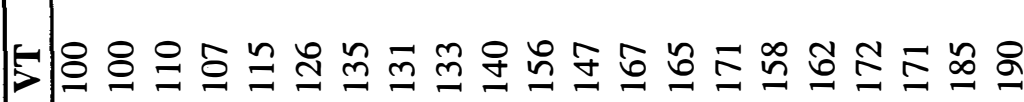

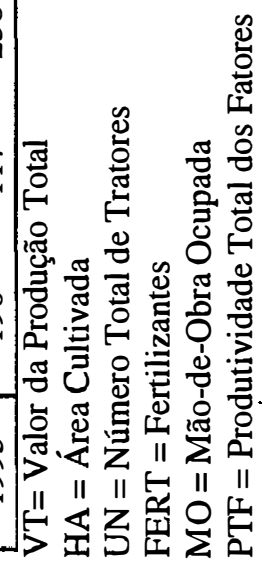


Com o esquema contábil construído é possível dimensionar qual o efeito das medidas alternativas do capital sobre o valor da PTF. Na tabela 11 aparecem as produtividades parciais do capital nas suas diferentes medidas. Quando o estoque é medido em número (UN) ou em cavalos $(\mathrm{CV})$, a produtividade do capital cai algo entre 20 e $30 \%$ no período; se medido em valor, a produtividade do capital aumenta $20 \%$.

É sensível a diferença causada no cômputo da PTF: ela oscila entre um aumento de $16 \%$ no período (estoque em cv) e uma elevação de $36 \%$ (estoque em valor). Dessa maneira pode-se visualizar através da tabela 11 o que Griliches afirmava em trecho citado no capítulo anterior: quando as mudanças qualitativas são incorporadas aos fatores, é possível explicar qual a fonte do crescimento do produto. ${ }^{34}$ Se o capital for medido adequadamente, reduz-se a parcela de aumento da PTF: a elevação do volume de cavalo-vapor empregado na produção explicou uma parcela maior do crescimento do produto, "roubando" do resíduo (PTF) cerca de $20 \%$ de elevação.

\footnotetext{
${ }^{34}$ É importante que se diga que Griliches sugeria que as mudanças qualitativas fossem captadas através de aumento nos preços dos insumos. $\mathrm{O}$ autor recomenda que o pesquisador selecione alguns itens do bem em estudo (como por exemplo, a potência do trator, alterações em seu sistema de transmissão, melhorias no sistema hidráulico, etc); ao longo do tempo deve-se acompanhar o aumento nos preços do equipamento captando qual o valor de cada melhoria adicional. Este aumento de valor deveria ser utilizado para "inflar" a série em questão. No presente estudo, esse procedimento não foi adotado em boa medida por conta das distorções nos preços decorrentes da alta inflação.
} 
Tabela 11 - Produtividades Parciais do Capital e Produtividade Total dos Fatores com Diferentes Formas de Mensuração do Estoque

\begin{tabular}{ccccccc}
\hline & \multicolumn{3}{c}{ Produtividade Parcial do Capital } & \multicolumn{3}{c}{ Produtividade Total dos Fatores } \\
\hline Ano & CV & Unidade & Valor & CV & Unidade & Valor \\
\hline 1975 & 100 & 100 & 100 & 100 & 100 & 100 \\
1976 & 82 & 84 & 83 & 94 & 94 & 94 \\
1977 & 82 & 84 & 84 & 95 & 96 & 96 \\
1978 & 73 & 75 & 77 & 87 & 88 & 89 \\
1979 & 70 & 73 & 76 & 90 & 92 & 93 \\
1980 & 72 & 75 & 79 & 100 & 102 & 103 \\
1981 & 74 & 77 & 84 & 102 & 104 & 106 \\
1982 & 69 & 74 & 82 & 97 & 99 & 103 \\
1983 & 69 & 73 & 84 & 103 & 106 & 110 \\
1984 & 69 & 74 & 85 & 101 & 103 & 108 \\
1985 & 72 & 78 & 92 & 104 & 107 & 112 \\
1986 & 63 & 68 & 82 & 97 & 100 & 106 \\
1987 & 69 & 74 & 91 & 109 & 112 & 120 \\
1988 & 65 & 71 & 90 & 105 & 108 & 116 \\
1989 & 66 & 72 & 94 & 109 & 112 & 121 \\
1990 & 60 & 65 & 88 & 102 & 105 & 115 \\
1991 & 61 & 67 & 94 & 110 & 113 & 126 \\
1992 & 65 & 71 & 104 & 108 & 111 & 125 \\
1993 & 65 & 71 & 106 & 109 & 112 & 127 \\
1994 & 69 & 76 & 112 & 115 & 119 & 134 \\
1995 & 73 & 80 & 120 & 116 & 120 & 136 \\
\hline
\end{tabular}

Os resultados encontrados se assemelham aos do trabalho de Bonelli e Fonseca (1998). Ao comparar os dois trabalhos chama a atenção a semelhança entre as séries de capital. $\mathrm{O}$ estoque dos referidos autores foi medido em unidades de tratores e o aumento na PTF no período de 1975 a 1995 foi de $15 \%$. Os autores não apresentam quais as ponderações adotadas, mas quando se coloca a série de Bonelli e Fonseca (1998) no esquema contábil ora apresentado, chega-se a um valor idêntico ao indicado na tabela 11. Da mesma forma, se o estoque em valor, ora desenvolvido, for colocado na estrutura contábil dos autores acima citados, chega-se a um aumento de 30\% na PTF (comparável aos $36 \%$ contidos na tabela 11 ).

Considerando que o esquema de contabilidade não fez uso da participação do rebanho no produto total, pode-se estar introduzindo um viés nos resultados. Além disso, 
um dos problemas inerentes ao esquema é que a participação dos fatores é mantida constante em todo o período. $\mathrm{Na}$ seção seguinte serão apresentados os resultados relativos aos cálculos do índice de Tornquist. Com base na participação média de cada um dos fatores será possível introduzir no esquema da contabilidade a variável rebanho. Será possível, também, comparar os resultados dos diferentes métodos.

\section{Os Resultados do Índice de Tornquist}

Conforme dito na seção 5.2.3, o maior problema encontrado na utilização do método de Tornquist foi a medida da participação do capital no produto. Era importante que o valor adotado reproduzisse da melhor forma possível o valor do serviço do capital. A inexistência de dados relativos ao valor de aluguel dos tratores, bem como de informações acerca do número de horas trabalhadas por ano, forçou a adoção de medidas alternativas. Três séries distintas foram selecionadas, quais sejam: i) o valor do estoque; ii) o valor do produto físico marginal dos tratores; iii) o valor do trator no último ano de vida, deduzido o valor de sucata ( $10 \%$ do valor de um trator novo), acrescido dos custos de manutenção (equivalente a $5 \%$ do valor de um trator novo) ${ }^{35}$ e dos gastos com combustível. No último caso, admitiu-se que um trator estaria trabalhando até 25 anos. Para calcular a depreciação entre as idades de 21 a 25 anos utilizou-se a taxa de 5\%, que é a taxa para onde a variação dos preços converge a partir dos 9 anos de uso do trator (vide figura 4). A idéia por trás dessa alternativa é que o preço de um trator reflete o valor dos serviços realizados no presente, acrescido do valor descontado dos serviços futuros. Assim, em se tomando o valor do trator no último ano de vida, tem-se o equivalente ao valor do serviço atribuído pelo mercado a apenas 1 ano de trabalho do trator. Esta última medida servirá mais como avaliação da sensibilidade dos resultados.

\footnotetext{
${ }^{35}$ Os gastos com manutenção foram baseados em Teixeira e Balastreire (1996). Os autores estimam que um trator que trabalhe 10.000 horas tem um custo de manutenção acumulado equivalente a $58,32 \%$ do valor de um trator novo. Admitindo-se que um trator trabalhe 800 horas por ano, chega-se a um dispêndio anual com manutenção da ordem de $4,7 \%$ ao ano.
} 
O cálculo do valor do produto físico marginal do capital foi efetuado multiplicando-se o valor do produto físico médio pelo coeficiente estimado na função Cobb-Douglas (igual a 0,2995). Adotou-se o coeficiente da função que tinha como variável o valor da produção de lavouras. Como já discutido, é ele que melhor representa o componente de máquinas. A tabela 12 apresenta os cálculos efetuados. A primeira coluna exprime o valor do produto físico médio; em decorrência do uso crescente de tratores no período considerado percebe-se que o produto físico médio é decrescente entre 1975 e 1995. O mesmo ocorre com o produto físico marginal do capital, como era de se esperar dado o forte processo de acumulação de capital apresentado no capítulo 4 . A terceira coluna indica o valor total dos serviços fornecidos pelo estoque de tratores. Esse valor é obtido multiplicando-se o produto marginal do capital pelo número de tratores existentes em cada ano. As duas últimas colunas da tabela indicam a taxa de retorno sobre o capital investido. Considerou-se o preço do trator de duas faixas distintas de potência (de $75 \mathrm{cv}$ e de $140 \mathrm{cv}$ ); os preços adotados ( $\mathrm{R} \$ 35.000$ e $\mathrm{R} \$ 51.000$, respectivamente) são do IEA. A taxa de retorno ao investimento encontrou-se entre $20 \mathrm{e}$ $30 \%$ no ano de 1995, muito próxima daquelas citadas por Griliches (1963 a) para os Estados Unidos. Como aponta o mesmo autor, essa taxa deve-se aproximar consideravelmente da taxa de desconto efetivamente utilizada pelos produtores rurais. Encontra-se bem distante dos juros do Sistema Nacional de Crédito Rural, que por vezes é utilizado como aproximação do valor do serviço do capital. Os valores calculados de cada uma das séries encontram-se no Apêndice B. 
Tabela 12 - Valor do Produto Físico Médio, do Produto Físico Marginal e Taxa de Retorno do Capital Investido para Tratores de 75 e de $140 \mathrm{cv}$ (valores em $R$ \$ de dezembro de 1995)

\begin{tabular}{cccccc}
\hline Ano & PFMe K & PFMg K & Valor Serviço de K & Retorno (75 cv) & Retorno (140 cv) \\
\hline 1973 & 73.487 & 22.009 & 5.185 .454 .794 & $61 \%$ & $43 \%$ \\
1974 & 73.532 & 22.023 & 6.091 .500 .919 & $61 \%$ & $43 \%$ \\
1975 & 59.867 & 17.930 & 5.938 .706 .870 & $50 \%$ & $35 \%$ \\
1976 & 47.524 & 14.233 & 5.624 .807 .684 & $40 \%$ & $28 \%$ \\
1977 & 48.975 & 14.668 & 6.409 .577 .332 & $41 \%$ & $29 \%$ \\
1978 & 46.596 & 13.956 & 6.582 .260 .469 & $39 \%$ & $27 \%$ \\
1979 & 42.220 & 12.645 & 6.534 .619 .084 & $35 \%$ & $25 \%$ \\
1980 & 40.956 & 12.266 & 6.809 .364 .392 & $34 \%$ & $24 \%$ \\
1981 & 44.637 & 13.369 & 7.689 .928 .055 & $37 \%$ & $26 \%$ \\
1982 & 41.744 & 12.502 & 7.383 .967 .565 & $35 \%$ & $25 \%$ \\
1983 & 39.475 & 11.823 & 7.116 .438 .764 & $33 \%$ & $23 \%$ \\
1984 & 43.080 & 12.902 & 8.141 .573 .009 & $36 \%$ & $25 \%$ \\
1985 & 45.767 & 13.707 & 9.094 .548 .813 & $38 \%$ & $27 \%$ \\
1986 & 36.586 & 10.957 & 7.874 .614 .184 & $30 \%$ & $21 \%$ \\
1987 & 41.885 & 12.545 & 9.404 .495 .793 & $35 \%$ & $25 \%$ \\
1988 & 34.579 & 10.356 & 7.975 .685 .397 & $29 \%$ & $20 \%$ \\
1989 & 34.811 & 10.426 & 8.238 .862 .115 & $29 \%$ & $20 \%$ \\
1990 & 31.616 & 9.469 & 7.593 .235 .067 & $26 \%$ & $19 \%$ \\
1991 & 32.024 & 9.591 & 7.726 .379 .442 & $27 \%$ & $19 \%$ \\
1992 & 33.423 & 10.010 & 8.017 .651 .041 & $28 \%$ & $20 \%$ \\
1993 & 33.032 & 9.893 & 7.922 .061 .758 & $27 \%$ & $19 \%$ \\
1994 & 35.301 & 10.573 & 8.563 .230 .161 & $29 \%$ & $21 \%$ \\
1995 & 35.958 & 10.770 & 8.492 .575 .877 & $30 \%$ & \\
\hline & & & & & $2 \%$ \\
\hline
\end{tabular}

O método científico não permite que se faça uso de fontes informais de informação. Havia, entretanto, uma grande preocupação em que os cálculos ora apresentados guardassem alguma correlação com os valores encontrados rotineiramente no mercado. Embora não exista fonte de coleta sistemática de informações acerca do aluguel de tratores, diversas cooperativas e empresas especializadas alugam os serviços de suas máquinas aos produtores. A fim de checar a consistência dos dados realizaramse algumas entrevistas com esses prestadores de serviços. A FNP Consultores, por exemplo, divulga uma tabela com o custo anual de manutenção de tratores. Um trator 
MF 275 (com potência próxima à média nacional) que trabalhe 800 horas por ano apresenta um custo horário de U\$ 15,12. Tomando-se os dados do Censo Agropecuário de 1985 como base, verifica-se que o consumo de óleo diesel foi, naquele ano, equivalente a 3 bilhões de litros. O consumo específico de um trator de $75 \mathrm{cv}$ é de 6 litros de óleo por hora trabalhada. Dividindo-se o total de óleo diesel consumido pelo número de tratores em 1985 (652.049), chega-se a um número de horas trabalhadas por trator de, aproximadamente, 750 horas/ano. Se essa quantidade de horas por trator por ano de trabalho seguir valendo para o ano de 1995 (e não existe nenhuma grande razão para que tenha alterado muito), o valor estimado do custo operacional anual total seria, em reais de 1995, da ordem de $\mathrm{R} \$ 9,5$ bilhões, que é um valor não muito distante do encontrado pelo método da produtividade marginal do capital. Dados levantados junto a uma cooperativa do Estado de São Paulo indicam que o preço de aluguel de um trator de $65 \mathrm{cv}$ foi, em novembro de 1998, de R\$17,00 por hora trabalhada. Esse valor equivaleria a $R \$ 13,7$ por hora trabalhada em reais de dezembro de 1995 , o que resultaria num custo anual total equivalente a $\mathrm{R} \$ 8,25$ bilhões, também semelhante ao valor indicado na tabela 12. Vale, contudo, repetir: esses dados apresentados servem apenas como indicação de que os métodos considerados não estão distantes dos observados no mercado de fatores.

De posse dos valores do serviço do capital calculou-se o índice de produtividade total do fatores pelo método não-paramétrico. Além de medir a variação dos resultados às diferentes 'formas de mensuração do valor do serviço do capital, foram feitas estimativas do índice considerando ou não o rebanho animal dentre os insumos de produção. Os resultados estão compilados na tabela 13. Pode-se perceber que os resultados alcançados com o uso do Índice de Tornquist são um pouco superiores aos calculados pelo método da contabilidade. Assemelham-se mais ao valor da PTF alcançado com o uso do estoque em valor. Note-se que o impacto das diferentes formas de medida do valor dos serviços não é trivial: o ganho na PTF acumulado no período salta de $30 \%$ para $40 \%$. O mesmo ocorre ao se considerar o estoque de animais no denominador do índice de Tornquist; novamente percebe-se um ganho adicional de $10 \%$ 
na PTF acumulada entre 1975 e 1995. De um modo geral observa-se que os ganhos de produtividade total foram próximos a $35 \%$ no período.

\section{Tabela 13 - Evolução da Produtividade Total dos Fatores Medida pelo Método do Índice de Tornquist}

\begin{tabular}{ccccccc}
\hline & \multicolumn{3}{c}{ TONQUIST COM REBANHO } & \multicolumn{3}{c}{ TONQUIST SEM REBANHO } \\
\hline ano & Valor Estoque & Valor PMg Capital & Valor Serviço & Valor Estoque & Valor PMg Capital & Valor Serviço \\
\hline 1975 & 100 & 100 & 100 & 100 & 100 & 100 \\
1976 & 93 & 91 & 93 & 93 & 91 & 94 \\
1977 & 99 & 97 & 100 & 98 & 95 & 99 \\
1978 & 98 & 96 & 100 & 97 & 94 & 99 \\
1979 & 102 & 99 & 103 & 102 & 98 & 104 \\
1980 & 109 & 106 & 112 & 113 & 108 & 117 \\
1981 & 118 & 114 & 121 & 123 & 117 & 127 \\
1982 & 112 & 108 & 114 & 115 & 110 & 119 \\
1983 & 120 & 116 & 123 & 124 & 118 & 129 \\
1984 & 114 & 110 & 116 & 114 & 109 & 117 \\
1985 & 131 & 126 & 134 & 124 & 119 & 129 \\
1986 & 110 & 106 & 113 & 113 & 107 & 118 \\
1987 & 124 & 120 & 128 & 129 & 122 & 134 \\
1988 & 119 & 115 & 122 & 123 & 116 & 128 \\
1989 & 123 & 119 & 127 & 128 & 122 & 134 \\
1990 & 119 & 116 & 123 & 126 & 121 & 132 \\
1991 & 126 & 123 & 130 & 135 & 131 & 143 \\
1992 & 126 & 121 & 130 & 134 & 127 & 141 \\
1993 & 126 & 122 & 130 & 134 & 126 & 140 \\
1994 & 133 & 128 & 137 & 141 & 133 & 148 \\
1995 & 136 & 131 & 140 & 145 & 137 & 151 \\
\hline
\end{tabular}

Com bảse nas participações dos fatores calculadas pelo método do número índice é possível agora construir o esquema da contabilidade dando conta do estoque de animais. ${ }^{36}$ Adotando-se a média do período como critério de ponderação, chega-se aos valores da tabela 14. Pode-se perceber que a diminuição relativa do peso das máquinas no estoque de capital total atenua as diferenças acarretadas pelas distintas formas de medida do capital. Enquanto a amplitude das diferenças entre as séries é de 12 pontos percentuais na contabilidade com o rebanho incluído, no cômputo sem o estoque de

\footnotetext{
${ }^{36}$ As participações dos fatores estão compiladas no apêndice B. As ponderações adotadas para o cálculo da tabela 14 foram: $13 \%$ para área; $19 \%$ para capital; $8 \%$ para fertilizantes; $33 \%$ para mão-de-obra e $27 \%$ para o rebanho.
} 
animais ela é de 20 pontos. Além disso, existe uma grande proximidade entre os resultados da contabilidade (com valor do estoque de máquinas) e aqueles alcançados no cálculo do índice de Tornquist. Essa proximidade garante boa consistência aos resultados pois é comum nos estudos de produtividade a obtenção de resultados distintos conforme o método adotado. Isto será examinado adiante.

Tabela 14 - Evolução da Produtividade Total dos Fatores Medida pelo Método da Contabilidade

\begin{tabular}{ccccccc}
\hline & \multicolumn{2}{c}{ CONTABILIDADE com REBANHO } & \multicolumn{3}{c}{ CONTABILDADE sem REBANHO } \\
\hline ANO & UNWADE & C.V. & VALOR & Unidade & C.V. & Valor \\
\hline 1975 & 100 & 100 & 100 & 100 & 100 & 100 \\
1976 & 95 & 95 & 95 & 94 & 94 & 94 \\
1977 & 100 & 99 & 100 & 96 & 95 & 96 \\
1978 & 94 & 93 & 94 & 88 & 87 & 89 \\
1979 & 96 & 96 & 97 & 92 & 90 & 93 \\
1980 & 106 & 105 & 107 & 102 & 100 & 103 \\
1981 & 110 & 108 & 111 & 104 & 102 & 106 \\
1982 & 105 & 104 & 108 & 99 & 97 & 103 \\
1983 & 112 & 110 & 115 & 106 & 103 & 110 \\
1984 & 110 & 109 & 114 & 103 & 101 & 108 \\
1985 & 120 & 118 & 124 & 107 & 104 & 112 \\
1986 & 107 & 105 & 111 & 100 & 97 & 106 \\
1987 & 120 & 119 & 125 & 112 & 109 & 120 \\
1988 & 117 & 115 & 122 & 108 & 105 & 116 \\
1989 & 120 & 118 & 126 & 112 & 109 & 121 \\
1990 & 112 & 110 & 118 & 105 & 102 & 115 \\
1991 & 118 & 116 & 126 & 113 & 110 & 126 \\
1992 & 117 & 115 & 126 & 111 & 108 & 125 \\
1993 & 118 & 116 & 127 & 112 & 109 & 127 \\
1994 & 125 & 123 & 135 & 119 & 115 & 134 \\
1994 & 125 & 123 & 136 & 120 & 116 & 136 \\
\hline
\end{tabular}

\section{Resumo dos Resultados}

Dentre as simulações realizadas, quatro delas apresentam as melhores espéecificações. No método da contabilidade a inclusão da variável rebanho tornou os 
resultados coerentes com aqueles obtidos pelo número índice. Além disso, o produto total considera a produção de origem animal, o que torna recomendável a inclusão do rebanho entre os insumos produtivos. No caso do índice de Tornquist a medida mais adequada é a que faz uso da produtividade marginal do capital uma vez que é a única que mede precisamente o valor atribuído pelo mercado ao serviço do capital.

Dessa maneira selecionaram-se as três séries da contabilidade com rebanho e o índice de Tornquist, incluindo a série de produtividade marginal do capital. Essas séries encontram-se na figura 8. Percebe-se que os ganhos da PTF encontram-se entre $23 \%$ e $36 \%$ no período. Esse aumento acumulado da PTF corresponderia às taxas anuais de crescimento de $1 \%$ e de $1,6 \%$, respectivamente.

Esses ganhos de produtividade encontraram-se associados a um crescimento do produto de $3,26 \%$ ao ano. Utilizando a taxa geométrica de aumento de cada um dos insumos, ponderado pela participação dos mesmos no produto, é possível concluir que na média dos exercícios realizados a participação dos insumos no crescimento do produto foi de $2 / 3$. Portanto, pode-se notar que a participação da produtividade total dos fatores na expansão do produto total foi da ordem de 1/3. Esses números dão indicação da relevância dos insumos modernos na elevação da produção agrícola brasileira no período de 1975 a 1995, pois vale lembrar que a variação no número total de pessoas ocupadas entre esses anos foi nula (vide quadro 5). 


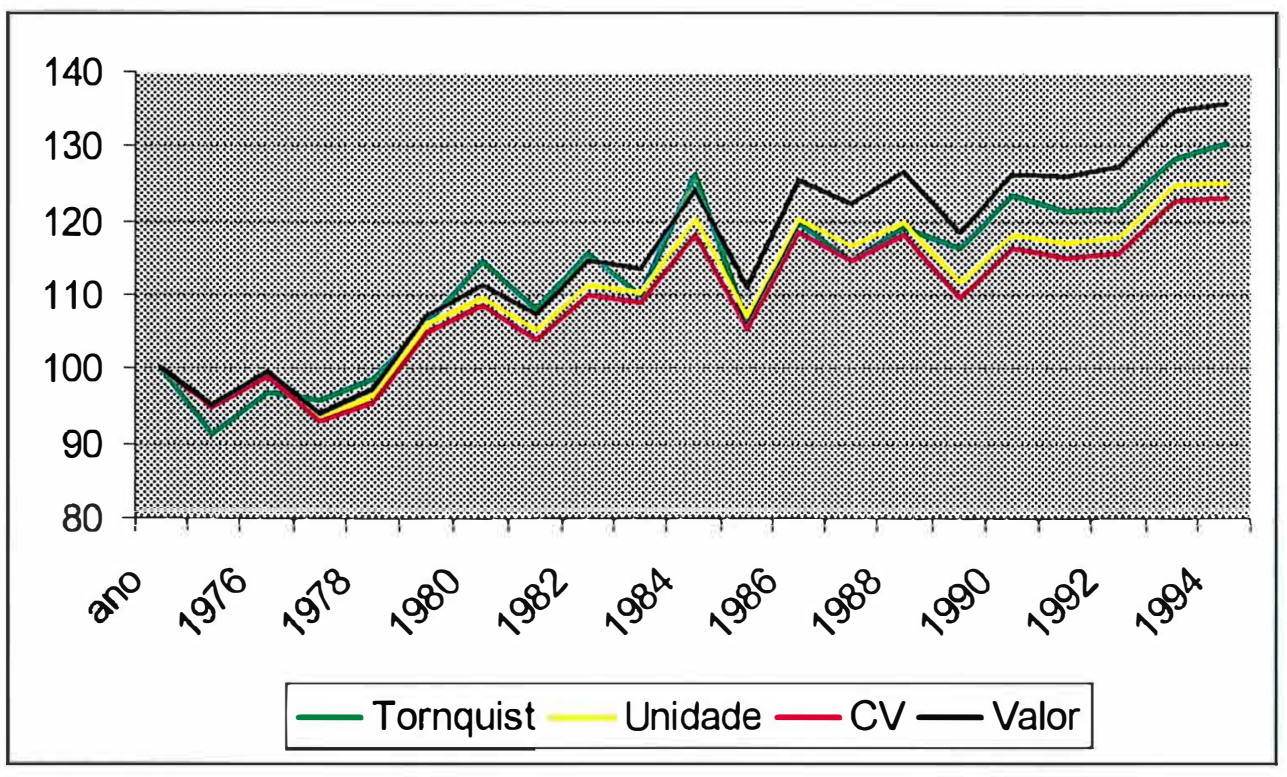

Figura 8 - Evolução da Produtividade Total dos Fatores entre os Anos de 1975-1995

\section{Comparando com Outros Resultados}

Característica marcante na análise de diferentes estudos de produtividade é a diversidade de resultados alcançados. Conforme já foi possível perceber, os resultados são sensíveis à forma de tratamento dada aos insumos de produção, à estrutura de ponderação adotada, ao método de cômputo selecionado. Assim, é natural que ocorram divergências dos resultados encontrados. Existe, entretanto, um padrão de crescimento da agricultura no longo prazo mais ou menos comum a muitos países. O quadro 6 condensa uma série de resultados obtidos em estudos internacionais.

A literatura resenhada indica que numa perspectiva de prazo mais longo, a PTF na agricultura dos países desenvolvidos aumenta a uma taxa anual que varia entre 1,5 e $2 \%$ ao ano, como pode ser percebido com auxílio do quadro 6 . Existem alguns períodos de rápida aceleração, muito embora tais períodos não sejam muito maiores do que 5 anos. O caso da China é emblemático nesse sentido: no período de 1978 a 1984 cresceu a $7,7 \%$ ao ano, a taxa mais elevada encontrada na revisão de literatura realizada. Mesmo 
assim, é possível notar que a taxa de crescimento da agricultura chinesa em 20 anos foi de $2,13 \%$ a.a..

Outro fato que caracteriza os estudos internacionais é a distância frequentemente encontrada entre as taxas de crescimento da PTF dos países desenvolvidos e subdesenvolvidos. Em geral, o padrão de evolução da PTF é bem inferior nos países subdesenvolvidos, onde é comum encontrar decréscimo da produtividade em períodos relativamente longos de tempo. A taxa padrão de crescimento desse bloco de países é marcado por um valor inferior a $1 \%$ ao ano, como pode ser visto no quadro 6 .

Esses resultados internacionais contrastam com alguns estudos acerca da evolução da PTF na agricultura brasileira. Existe na literatura consultada uma amplitude muito grande de resultados relativos ao desempenho do setor agrícola do paísentre 1960 e 1995. O quadro 7, a seguir, abaixo resume os resultados dos principais estudos publicados. 
Quadro 6 - Ganhos Anuais da Produtividade Total dos Fatores na Agricultura de Diversos Países

\begin{tabular}{|c|c|c|c|}
\hline País & Período & PTF (\% anual) & Autores \\
\hline Estados Unidos & $\begin{array}{l}1947-1985 \\
1070-1085\end{array}$ & $\begin{array}{l}1,58 \\
258\end{array}$ & Jorgenson e Gollop \\
\hline Canadá & $1948-1991$ & $\begin{array}{l}1,50 \\
1,88\end{array}$ & $\begin{array}{c}\text { Fantine e Veeman } \\
\text { (1994) }\end{array}$ \\
\hline \begin{tabular}{|l|} 
Austrália \\
\end{tabular} & & 2,50 & Mullen e Cox (1996) \\
\hline China & $1965-1985$ & 2,13 & Fan (1991) \\
\hline China & $\begin{array}{l}1970-1978 \\
1978-1984 \\
1984-1987\end{array}$ & $\begin{array}{c}-5,60 \\
7,7 \\
2,8\end{array}$ & $\begin{array}{l}\text { Kalirajan et alii } \\
\text { (1996) }\end{array}$ \\
\hline $\begin{array}{l}\text { Alemanha Ocidental } \\
\text { França } \\
\text { Itália } \\
\text { Holanda } \\
\end{array}$ & 1963-1976 & $\begin{array}{l}2,02 \\
1,61 \\
1,17 \\
2,45 \\
\end{array}$ & $\begin{array}{l}\text { Behrens e Haen } \\
\text { (1980) }\end{array}$ \\
\hline $\begin{array}{l}\text { India } \\
\text { Bangladesh } \\
\text { Paquistão }\end{array}$ & $1957-1985$ & $\begin{array}{l}1,01 \\
0,78 \\
1,07\end{array}$ & $\begin{array}{c}\text { Rosegrant e Evenson } \\
\text { (1992) }\end{array}$ \\
\hline $\begin{array}{l}22 \text { países } \\
\text { subdesenvolvidos }\end{array}$ & $\begin{array}{l}1960-1970 \\
1970-1980 \\
\end{array}$ & $\begin{array}{c}0,42 \\
-0,25 \\
\end{array}$ & $\begin{array}{c}\text { Lau e Yotopoulos } \\
\text { (1989) }\end{array}$ \\
\hline $\begin{array}{l}21 \text { países } \\
\text { desenvolvidos }\end{array}$ & $\begin{array}{l}1960-1970 \\
1970-1980 \\
\end{array}$ & $\begin{array}{l}0,98 \\
0,70\end{array}$ & $\begin{array}{c}\text { Lau e Yotopoulos } \\
\text { (1989) }\end{array}$ \\
\hline $\begin{array}{l}18 \text { países } \\
\text { subdesenvolvidos }\end{array}$ & 1961-1985 & $-2,10$ & $\begin{array}{c}\text { Fulginiti e Perrin } \\
\text { (1998) }\end{array}$ \\
\hline
\end{tabular}

As diferenças nos resultados são sensíveis. Enquanto Dias e Bacha (1998) encontram um crescimento anual de 4,3\% ao ano entre 1970 e 1985, Arnade (1992) estima a taxa de $2,25 \%$ ao ano e Ávila e Evenson (1995) de 2,45\% a.a.. O resultado apresentado pelos primeiros autores indica que a taxa de crescimento da PTF foi extremamente alta entre 1980 e 1985, uma vez que a taxa anual de aumento da PTF entre 1970 e 1980 foi de apenas $1,98 \%$ ao ano (vis-a-vis os 4,3\% do período 70-85). É digno de nota que os três autores fizeram uso do mesmo método, qual seja, o Índice de Tornquist. 
A referência mais contrastante do período de 1960 a 1985 é a de Fulginiti e Perrin (1998). Utilizando o índice de Malmquist (índice que não leva em consideração os preços, mas apenas as quantidades), esses autores encontram uma taxa anual de decréscimo da PTF de $-1,6 \%$ ao ano. Ou seja, valor muito distante daqueles estimados por Dias e Bacha (1998).

\section{Quadro 7 - Ganhos Anuais da Produtividade Total dos Fatores na Agricultura Brasileira}

\begin{tabular}{|c|c|c|c|}
\hline PTF (\% anual) & Período & Método & Autores \\
\hline 3,88 & $1976-1994$ & Índice de Tornquist & Gasques e Conceição \\
4,50 & $1976-1985$ & & $(1998)$ \\
3,11 & $1986-1994$ & & \\
\hline 4,30 & $1970-1985$ & Indice de Tornquist & Dias e Bacha (1998) \\
2,24 & $1970-1975$ & & \\
1,96 & $1970-1980$ & & \\
\hline 2,45 & $1970-1985$ & Índice de Tornquist & Ávila e Evenson \\
& & & $(1995)$ \\
\hline 2,25 & $1970-1985$ & Índice de Tornquist & Arnade (1992) \\
3,20 & $1975-1985$ & & \\
\hline 0,87 & $1975-1996$ & Contabilidade & Bonelli e Fonseca \\
0,00 & $1975-1990$ & & $(1998)$ \\
2,94 & $1990-1996$ & & \\
\hline 0,80 & $1955-1994$ & Função Custo & Conceição (1998 b) \\
2,00 & $1975-1994$ & & \\
\hline$-1,60$ & $1961-1985$ & Índice de Malmquist & Fulginiti e Perrin \\
& & & $(1998)$ \\
\hline
\end{tabular}

O estudo de prazo mais longo encontrado na literatura é o de Conceição (1998). Trabalhando num período que vai de 1955 a 1994 o autor encontra uma taxa equivalente a $0,8 \%$. Esse valor encontra-se dentro do padrão geral de evolução da agricultura internacional. O autor encontra, ainda, que entre 1975 e 1994 a taxa de elevação da PTF foi de $2 \%$ ao ano, também coerente com o que se conhece sobre a agricultura em processo de modernização. 
Além deste último trabalho, apenas dois outros levaram em conta o período pós1985. O artigo de Bonelli e Fonseca (1998) encontra uma taxa de crescimento da PTF na agricultura brasileira de 0,87\% ao ano entre 1975 e 1996. Os autores calculam que entre 1975 e 1990 a PTF não aumentou; nos últimos seis anos da série, entretanto, a taxa de crescimento passou a ser de $2,94 \%$ ao ano.

O estudo de Gasques e Conceição (1998) acha uma taxa média de crescimento entre 1975 e 1994 de 3,8 \% ao ano. Ademais, a PTF registra taxas decrescentes ao longo do tempo: enquanto entre 1976 e 1985 cresceu a $4,5 \%$ ao ano, entre 1985 e 1994 ela cai para $3,11 \%$.

Esses resultados são bem mais altos do que os encontrados no presente estudo. Utilizando os resultados comuns ao método da contabilidade e ao do índice de Tornquist, chega-se a uma taxa de crescimento da PTF entre 1975 e 1995 igual a 1,6 \% ao ano, equivalente, portanto, à metade da encontrada por Gasques e Conceição (1998). Outro ponto de distinção, refere-se ao ritmo de crescimento da taxa. Nossos resultados indicam que o processo de elevação da taxa de crescimento da PTF tem início a partir dos anos 80 (1,9\% ao ano); entre 1975 e 1980 os ganhos foram bastante modestos ( $1 \%$ ao ano).

Pelo exposto, podem ser aventadas algumas causas das diferenças dos resultados alcançados. Em primeiro lugar, encontra-se o tratamento dado a série de capital. Gasques e Conceição (1998), bem como Conceição (1998 b), fazem uso do método da depreciação linear de $10 \%$ ao ano para dimensionar os estoques de máquinas. Além dis̀so, utilizam como preço do capital o resultado obtido entre a divisão do faturamento da indústria de tratores e peças pelo total de máquinas vendidas. Esse preço foi multiplicado pelo número de tratores no estoque resultando no dispêndio total com tratores. A participação do capital encontrada por Conceição (1998) variou entre um máximo de 0,1\% e um mínimo de 0,04\%, no período de 1975 e 1994. Tais números contrastam com os encontrados no presente estudo, em que a participação do estoque conjunto de máquinas e fertilizantes é da ordem de $30 \%$ do dispêndio. 
Outra possível explicação para a divergência dos resultados refere-se ao uso do estoque de animais como insumo de produção. Gasques e Conceição (1998) não utilizam em sua análise essa variável, o que tende a elevar os valores da PTF encontrados. Além disso, os autores consideraram a produção de carne bovina no valor total da produção agrícola, ainda que não houvesse nenhum dado relativo a área de pastagem.

Ao somar a pequena participação do capital no produto à não inclusão do estoque de animais no denominador do índice de Tornquist, é possível concluir que a participação do trabalho no produto tende a ser mais elevada. Ora, como dentre todos os insumos o único que não mostrou aumento no período foi o pessoal ocupado, a maior parte da explicação do crescimento do produto acabou sendo atribuída à PTF. É interessante observar que a produtividade do trabalho e a PTF mostraram a mesma tendência de aumento $(4,02 \%$ e 3,885 ao ano, respectivamente).

Existe, ainda, um possível problema com esse resultado. Como foi possível aumentar tão expressivamente a produtividade da mão-de-obra? Na literatura do crescimento são três as explicações encontradas para o aumento da produtividade do trabalho, quais sejam: i) elevação do volume de capital humano acumulado; ii) progresso tecnológico; e, iii) aumento na relação capital/trabalho. É difícil imaginar que num intervalo de tempo de 20 anos tenha sido possível aumentar a produtividade do trabalho em $4 \%$ ao ano sem que houvesse elevação da relação capital trabalho e, portanto, sem que a participação do capital no produto tivesse aumentado. A taxa de progresso tecnológico, bem como o aumento do nível educacional médio da força de trabalho são variáveis que se alteram de forma mais lenta. 


\section{6 - CONCLUSÃO}

Esta pesquisa analisa o processo de formação de capital na agricultura brasileira entre 1970 e 1995, tendo como preocupação central estabelecer relações entre estoque de capital, produtividade e crescimento da agricultura.

A relação entre capital e crescimento econômico era tida, nos primórdios da teoria do crescimento, como o elemento chave na explicação da elevação do produto per capita. Em outras palavras, o capital constituía preocupação maior dos estudiosos da economia do crescimento econômico. Entretanto, o tempo encarregou-se de desviar o foco da análise econômica para a direção do acúmulo de capital humano e do desenvolvimento tecnológico. Boa parte da nova teoria do crescimento dedica-se a entender e dimensionar quais as relações entre a quantidade de capital humano acumulada e a taxa de crescimento das economias.

Essa mudança de ênfase tem sua razão de ser. Os estudos empíricos referentes ao crescimento dos países desenvolvidos dão conta que a maior parte do crescimento de longo prazo dessas economias pode ser atribuída ao aumento na produtividade total dos fatores, e não à variação no volume de capital acumulado. Economias com elevada dotação de capital apresentam baixos retornos aos investimentos em capital físico.

Ocorre que, se existe uma tendência de redução da importância relativa do capital na explicação do aumento no produto das economias desenvolvidas, o mesmo não pode ser dito para economias em transição de um estágio de baixo desenvolvimento para níveis mais elevados. É natural que nessas economias os retornos marginais aos 
investimentos sejam altos dada a escassez relativa de capital. Ademais, é inerente aos estudos de contabilidade do crescimento, como evidenciado neste trabalho, que o capital desempenhe papel fundamental na qualidade dos resultados, uma vez que a taxa de progresso tecnológico é obtida por resíduo, ou seja, a consistência dos resultados encontra-se intimamente relacionada à forma como as séries de insumos são especificadas. Não é recomendável, portanto, esquivar-se das dificuldades intrínsecas à mensuração do capital; corre-se o risco de alcançar resultados pouco coerentes com a realidade. Conclusão relevante deste estudo, por exemplo, é que a depreciação e o modo de medir o estoque de capital estão intimamente associados com os ciclos econômicos.

As séries de capital aqui analisadas dão conta de um vigoroso processo de acumulação na agricultura brasileira entre os anos 70 e 90 . O estoque de máquinas aumentou 4 vezes em valor, 5 vezes em número e 6 vezes em potência entre 1970 e o final dos anos 80. Como proxy da relação capital/trabalho na agricultura, o número de pessoas ocupadas por trator diminuiu cerca de três vezes no mesmo período. Entretanto, essa tendência de crescimento do estoque reverteu-se, em boa medida, ao adentrar os anos 90. Fica claro que o volume de novos investimentos caiu substancialmente, sinalizando um processo de envelhecimento da frota de tratores.

Os resultados corroboram a visão na qual os recursos mobilizados pelo Estado através da política de crédito rural, principalmente entre o início dos anos 70 e meados dos anos 80, éxpandiram em larga escala a base produtiva do setor agrícola. No decorrer dos anos 80, quando se generaliza a crise do Estado e se agrava o quadro de instabilidade macroeconômica, reduz-se dramaticamente a capacidade de coordenação e promoção de políticas públicas setoriais. Como conseqüência disso, o ritmo de investimento na agricultura diminui progressiva e acentuadamente.

Se a taxa de investimento cai no final do período estudado, o mesmo não pode ser dito sobre a produtividade dos fatores. Esta é outra importante conclusão. A produtividade do trabalho aumentou à taxa de 3,26\% ao ano; a da terra, 2,47\%. Entre 1975 e 1995 a mudança no número de pessoas ocupadas foi praticamente nulo. Nestas 
mesmas datas a área cultivada aumentou apenas 17\%; entre 1980 e 1995 a variação na área foi insignificante. Esses números fazem crer que, de fato, diferentemente do ocorrido nos anos 70, a expansão da produção agrícola decorreu dos aumentos no uso de insumos modernos e de ganhos de produtividade. O ritmo de crescimento da produtividade total dos fatores situa-se entre $1 \%$ ao ano (quando o estoque é medido em potência) e 1,6\% ao ano (quando medido em valor). A diferença entre esses dois valores indica que quando a mudança qualitativa do insumo capital é incorporada à análise, a importância relativa da PTF declina. Embora não tão expressivo quanto os incrementos nas produtividades parciais, os ganhos na PTF encontram-se em concordância com a maior parte dos estudos internacionais. Isto é, num prazo mais longo e em geral, a PTF na agricultura aumenta à taxa média de $1 \%$ a $2 \%$ ao ano.

Chama atenção quando se analisa a evolução dos ganhos de produtividade total no período estudado que o ritmo de incremento da produtividade mostrou-se mais elevado a partir de meados dos anos 80. Observou-se que entre 1975 e 1980 praticamente não houve elevação da PTF. Esses resultados estão também de acordo com os antigos estudos de economia agrícola encontrados na literatura. É notório que a despeito do decréscimo nos investimentos em capital no setor agrícola, houve clara tendência de elevação da produtividade da agricultura.

A produção agrícola total expandiu à taxa de 3,26\% ao ano. Este crescimento foi explicado em larga medida pela expansão do uso de insumos modernos na agricultura. Nossos cálculos indicam que cerca de $2 / 3$ do aumento no produto foram decorrentes da elevação na quantidade utilizada de insumos. Como pessoal ocupado e área cultivada praticamente não se alteraram no período, coube ao capital a explicação maior do crescimento do produto. A outra parcela do aumento do produto (1/3) deveu-se à elevação na produtividade total dos fatores.

Estes resultados lançam uma sombra quanto às perspectivas futuras de crescimento da agricultura brasileira. Dada a grande relevância do capital no aumento da produção agrícola no passado recente e, além disso, dado o decréscimo nos níveis de 
investimentos nos últimos anos, fica difícil imaginar que a tendência de crescimento do produto se sustente por muito tempo. Há, portanto, que se equacionar o problema do financiamento dos investimentos produtivos.

Se o presente trabalho ilumina, em alguma medida, o processo de formação de capital, ele passa ao largo de outras questões ainda obscuras e referentes aos determinantes do crescimento da agricultura brasileira. Teria havido aumento de eficiência econômica com o decréscimo da interferência do Estado no setor ? Quanto do crescimento da produtividade total dos fatores pode ser resultante dos investimentos em pesquisa ? Qual a verdadeira dimensão do papel de capital humano no setor agrícola ? Teria havido um processo de concentração da produção ? Qual a dimensão social da saída de mão-de-obra do setor? Enfim, as mesmas perguntas de sempre. Aquelas que precisam ser respondidas. 


\section{7 - REFERÊNCIAS BIBLIOGRÁFICAS}

AIGNER, D. et al. Formulation and estimatioon of stochastic frontier productioon function models. Journal of Econometrics, v.5, n.1, p.21- 37, 1977.

AKERLOF, G. The market for "lemons": quality uncertainty and the market mechanism. Quaterly Journal of Economics, v.84, n.3, Aug.1970.

ALVES, E.; CONTINI, E. A modernização da agricultura brasileira. In : BRANDÃO, A.S.P. (Ed). Os principais problemas da agricultura brasileira. 2.ed. Rio de Janeiro: IPEA/INPES, 1992. p.49-98.

ARAÚJO, P.F.C.; MEYER, R.C. Política de crédito agrícola no Brasil : objetivos e resultados. In : Veiga, A. (Coord.). Ensaios sobre política agrícola brasileira. São Paulo: Secretaria da Agricultura, 1979. p.137-162.

ARAÚJO, P.F.C. et al. Descrição do Ensino na Área de Ciências Agrária. Brasília: Ministério da Educação e do Desporto, Secretaria de Educação Superior, Comissão de Especialistas de Ciências Agrárias, mimeo, 1996.

ARNADE, C.A Productivity and technical change in brazilian agriculture. Technical Bulletin Number, n.1811, 1992b. (Economic Research Service, US Department of Agriculture).

ARNADE, C.A. Productivity of brazilian agriculture: measurement and uses. Staff Report AGES n.9219, 1992a (Economic Research Service, US Department of Agriculture).

ARROW, K.J. "The economic implication of learning by doing", Review of Economic Studies, 29. 1962. 
ÁVILA, A.F.D.; EVENSON, R.E. Total factor productivity growth in the brazilian agriculture and the role of agricultural research. In: CONGRESSO BRASILEIRO DE ECONOMIA E SOCIOLOGIA RURAL, 33., Curitiba, 1995. Anais. Brasília: SOBER, 1995. p.631-657.

BARRO, R.J.; SALA-I-MARTIN, X. Economic growth. New York: McGraw-Hill, 1995. 539p.

BARROS, G.S.C. Investimento em tratores agrícolas no Brasil. Piracicaba, 1980. 135p. Tese (Livre-Docência) - Escola Superior de Agricultura Luiz de Queiroz, Universidade de São.

BEHRENS, R.; HAEN, H. Aggregate factor input and productivity in agriculture: a comparison for the EC-member countries, 1963-76. European Review of Agricultural Economics, v.7, n.2, p.109-146, 1980.

BERNDT, E.R. The practice of econometrics: classic and contemporary. Addison: Wesley Publishing Company. 1991. 702p.

BLANCHARD, O.J.; FISCHER, S. Lectures on macroeconomics. Cambridge: The MIT Press, 1989. 650p.

BONELLI, R.; FONSECA, R. Ganhos de produtividade e de eficiência: novos resultados para a economia brasileira. Brasília: IPEA, 1998. 43p. (Texto para Discussão n.557).

CHENERY, H.B. Interaction between theory and observation in development. Washington: World Development, 1983, v.II, p.233-40.

CHRISTENSEN, L.R. Concepts and measurements of agricultural productivity. American Journal of Agricultural Economics, v.57, n.5, p.910-915, 1975.

COCHRANE, W.W. Farm prices: myth and reality. 2.ed. Minneapolis: University of Minnesota Press, 1958. 
COCHRANE, W.W. The development of american agriculture: a historical analysis. 2.ed. Minneapolis: University of Minnesota Press, 1993. 464p.

CONCEIÇÃO, J.C.P.R. Fronteira estocástica e eficiência técnica na agricultura. Piracicaba, 1998. 108p. Tese (Doutorado) - Escola Superior de Agricultura Luiz de Queiroz, Universidade de São Paulo.

CONCEIÇÃO, P.H.Z. Produtividade total e mudança técnica na agricultura brasileira, período 1955-1994. Piracicaba, 1998. 88p. Tese (Doutorado)-Escola Superior de Agricultura Luiz de Queiroz, Universidade de São Paulo.

CRAMER, J.S. The depreciation and mortality of motor cars. Journal of The Royal Satistical Society, vol CXXI, série A, 1958.

CROSS, T.L.; PERRY, G.M. Depreciation patterns for agricultural machinery. American Journal of Agricultural Economics, v.77, n.1, p.194-204, 1995.

DENISON, E. Trends in american economic growth, 1929-82. Washington: The Brookings Institution, 1985.

DIAS, G.L.S. Avanços e perspectivas do agribusiness brasileiro. In: CONGRESSO BRASILEIRO E SOCIOLOGIA RURAL, 28., Florianópolis, 1990. Anais. Brasília: SOBER, 1990.

DIAS, G.L.S. O Papel da agricultura no processo de ajustamento estrutural do Brasil. In : ROCCA, C.A.(Org.). Brasil 1980. São Paulo: FIPE/USP, 1988. p.259-272.

DIAS, G.L.S. O papel da agricultura no processo de ajustamento estrutural do Brasil : nota adicional. In: CONGRESSO BRASILEIRO DE ECONOMIA E SOCIOLOGIA RURAL, 27., Piracicaba, 1989. Anais. Brasília, SOBER, 1989.

DIAS, G.L.S.; BARROS, J.R.M. Fundamentos para uma nova política agrícola. Brasília: Companhia de Financiamento da Produção, 1983. 39p. (Coleção Análise e Pesquisa, v.26). 
DIAS, R.S. Mudança técnica e viés de produção na agropecuária brasileira: 1970-1985. Piracicaba, 1998. 128p. Tese (Doutorado) - Escola Superior de Agricultura Luiz de Queiroz, Universidade de São Paulo.

DIAS, R.S.; BACHA, C.J.C. Produtividade e progresso tecnológico na agricultura brasileira: 1970-1985. In: CONGRESSO BRASILIERO DE ECONOMIA E SOCIOLOGIA RURAL, 36., Poços de Caldas, 1998. Anais. Brasília: SOBER, 1998. p.211-221.

DICKEY, D.A. et al. A primer on cointegration with na application to money and income. In: RAO, B.B. (Ed.). Cointegration for the applied economist. New York: Saint Martin's Press, 1994. 231p.

DIEWERT, W.E. Exact and superlative index numbers. Journal of Econometrics, v.4, n.2, p.115-145, 1976.

ELÍAS, V.J. Sources of growth: a study of seven Latin American economies. San Francisco: I.C.S. Press, 1992. 254p.

ENDERS, W. Applied econometric time series. New York: John Wiley \& Sons, 1995. $433 \mathrm{p}$.

FAN, S. Effects of technological change and institutional reform on production growth in chineśe agriculture. American Journal of Agricultural Economics, v.73, n2, p.266-275, 1991.

FELDSTEIN, M.S.; FOOT, D.K. The other half of gross investment: replacement and modernization expenditures. The Review of Economics and Statistics, v.53, n.1, p.49-58, 1971.

FERREIRA FILHO, J.B.S. Ajustamento estrutural e crescimento agrícola na década de oitenta : notas adicionais. Piracicaba: DESR/ESALQ/USP. (Mineo) 
FERREIRA FILHO, J.B.S. Notas a respeito do desempenho agregado da agricultura brasileira no período 1980-1991. Revista de Economia e Sociologia Rural, v.32, n.3, p.225-236, 1994.

FORSUND, F.R. A survey of frontier production functions and of their relationship to efficiency measurement. Journal of Econometrics, v.13, n.1, p.5-25, 1980.

FULGINITI, L.E.; PERRIN, R.K. Agricultural productivity in developing countries. Agricultural Economics, v.19, n.1, p.45-51, 1998.

FULGINITI, L.E.; PERRIN, R.K. Prices and productivity in agriculture. The Review of Economics and Statistics, v.74, n.3, p.471-482, 1993.

FURTADO, C. Teoria e política do desenvolvimento econômico. São Paulo: Nacional, 1977. 344p.

GASQUES, J.G.; CONCEIÇÃO, J.C.P.R. Crescimento e produtividade da agricultura brasileira. Brasília: IPEA, 1998. 21p. (Texto para discussão, no $502)$.

GOLDIN, I.; RESENDE, G.C. Agricultura brasileira na década de 80: crescimento numa economia em crise. Rio de Janeiro: IPEA,1993. 119p.

GRANGER, G.W.J.; NEWBOLD, P. Spurious regressions in econometrics. Journal of Econometrics, v.2, n.2, p.111-120, 1974.

GRILICHES, Z. Capital stock in investment function: some problems of concept and measurement. In : CHRIST, C.F. et al. Measurement in economics. Stanford: Stanford University Press, 1963a.

GRILICHES, Z. Measuring inputs in agriculture: a critical survey. Journal of Farm Economics, v.42, n.5, p.1411-431, 1960b. 
GRILICHES, Z. The demand for a durable input : farm tractors in the United States, 1921-57. In : HARBERGER, A.C. (Ed.) The demand for durable goods. Chicago: University of Chicago Press,1960a.

GRILICHES, Z. The sources of measured productivity growth: United States Agriculture, 1940-60. Journal of Political Economy, v.71, n.4, p.331-46, 1963 b.

GRILICHES, Z.; JORGENSON, D.W. Sources of measured productivity phange: capital input. American Economic Review, v.56, n.2, p.50-61, 1966.

HAMILTON, J.D. Time series analysis. New Jersey: Princeton University Press, 1994. 799p.

HARBERGER, A.C. The demand for durable goods. Chicago: University of Chicago Press, 1960.

HAYAMI, Y.; RUTTAN, V.W. Desenvolvimento agrícola: teoria e experiências internacionais. Brasília: EMBRAPA, 1988.

HOMEM de MELO, F.B. Instabilidade de renda e estabilização de preços agrícolas. Pesquisa e Planejamento Econômico, v.13, n.3, p.829-826, 1983.

HOMEM de MELO, F.B. Padrões de crescimento da oferta agrícola. In: ROCCA, C.A. (Org.). Brasil 1980. São Paulo: FIPE/USP, 1988. p.245-258.

HOMEM de MELO, F.B. Padrões de instabilidade entre culturas da agricultura brasileira. Pesquisa e Planejamento Econômico, v.9, n.3, p.819-44, 1979.

HOMEM de MĖLO, F.B. Tendência de queda nos preços reais de insumos agrícolas. Revista de Economia Política, v.12, n.1, p.141-146, jan/mar, 1992.

HOMEM de MELO, F.B.H. Agricultura brasileira: incerteza e disponibilidade de tecnologia. São Paulo, 1978. 142p. Tese (Livre- Docência) - Universidade de São Paulo. 
HULTEN, C.R. Productivity change, capacity utilization, and the sources of efficiency growth. Journal of Econometrics, v.33, n.1/2, p.31-49, 1986.

JOHNSON, D.G. The nature of the supply function for agricultural products. American Economic Review, v.40, n.4, p.539-64, 1950.

JONDROW, J. et al. On the estimation of technical inneficiency in the stochastic frontier production function model. Journal of Econometrics, v.19, n.2/3, p.233238, 1982.

JORGENSON, D.W. Capital theory and investment behavior. American Economic Review, v.53, n.2, p.247-259, 1963.

JORGENSON, D.W. (Ed.) Investment. Cambridge: MIT Press, 1996. v.II, p.125155: The economic theory of replacement and depreciation.

JORGENSON, D.W.; GOLLOP, F.M. Productivity growth in U.S. agriculture: a postwar perspective. American.Journal Agricultural Economic, v.74, n.3, p.745-750, 1992.

KALIRAJAN, K.P. et al. A decomposition do total factor productivity growth: the case of the chinese agricultural growth before and after reforms. American Journal of Agricultural Economics, v.78, n.2, p.331-338, 1996.

1

KOUTSOYANNIS, A. Theory of econometris. 2.ed. New York: MacMillan, 1977. $681 \mathrm{p}$.

LAU, L.J.; YOTOPOULOS, P.A. The meta-production function approach to technological change in world agriculture. Journal of Development Economics, v.31, n.2, p.241-269, 1989.

LUCAS, R.E. On the mecanics of economic development. Journal of Monetary Economics, v.22, n.1, p.3-42, 1988. 
MANOEL, A.; BARROS, J.R.M. Agricultura brasileira: transformações e perspectivas na década de 80. In: ENCONTRO NACIONAL DE ECONOMIA, Salvador, 1987. Anais. São Paulo: ANPEC, 1987. p.103-128.

McNEILL, R.C. Depreciation of farm tractors in british Columbia. Canadian Journal of Agricultural Economics, v.27, n.1, p.53-58, 1979.

MENDONÇA de BARROS, J.R. Política e desenvolvimento agrícola no Brasil. In : VEIGA, A. (Coord.) Ensaios sobre política agrícola brasileira. São Paulo: Secretaria da Agricultura, 1979. p.9-36.

MENDONÇA de BARROS, J.R. Transição e descontinuidade no crescimento agrícola. In : DIAS, G.L.S.; BARROS, J.R.M. Fundamentos para uma nova política agrícola. Brasília: Companhia de Financiamento da Produção, 1983. p.23-39. (Coleção Análise e Pesquisa, n.26).

MENDONÇA de BARROS, J.R.; GRAHAM, D.H. A agricultura brasileira e o problema da produção de alimentos. Pesquisa e Planejamento Econômico, v.8, n.3, 1978.

MENDONÇA de BARROS, J.R.; GRAHAM, D.H.; GAUTIER, H. Thirty years of agricultural growth in Brazil : crop performance, regional profile and recent policy review. Economic Development and Cultural Change, v.35, 1987.

MENDONÇA'de BARROS, J.R.; MANOEL, A. Insumos agrícolas: evolução recente e perspectivas. In: BRANDÃO, A.S. (Ed.) Os principais problemas da agricultura brasileira: análise e sugestões. 2.ed. Rio de Janeiro: IPEA/PNPE, 1992. p.295-332.

MENDONÇA de BARROS, J.R.; PASTORE, A.C.; RIZZIERI, J. A evolução da agricultura brasileira até 1970 . In: ARAÚJO, P.F.C.; SCHUH, G.E. Desenvolvimento da agricultura. São Paulo: Pioneira, 1983. v.4, p.257-278.

MITCHELL, D.O. et al. The world food outlook. Cambridge: Cambridge University Press, 1997. 
MUKHERJEE, C. et al. Econometrics and data analysis for developing countries. New York: Routledge, 1998. 496p.

MULLEN, J.D.; COX, T.L. Measurin productivity growth in Australian broadcare agriculture. Australian Journal of Agricultural Economics, v.40, n.3, p.189$210,1996$.

MUNDLAK, Y. Agricultural growth and world development. PROCEEDING INTERNATIONAL AGRICULTURAL ECONOMISTS, 20., Buenos Aires, 1988. Proceeding. England: Dartmouth Publishing Company, 1989.

NELSON, R.A; CAPUTO, M.R. Price change, maintenance, and the rate of depreciation. Review of Economics and Statistics, v.89, n.3, p.422-430, 1997.

NELSON, R.R. Research on productivity growth and productivity differences: dead ends and new departures. Journal of Economic Literature, v.19, n.3, p.10291064, 1981.

NISHIMIZU, M.; PAGE, J.M. Total factor productivity growth, technological progress and technical efficiency change: dimensions of productivity change in Yugoslavia, 1965-1978. Economic Journal, v.92; n.368, p.920-936, 1982.

PASTORE, A.C. Exportações agrícolas e desenvolvimento econômico. In: VEIGA, A. (Org.) Énsaios sobre política agrícola brasileira. São Paulo: Secretaria da Agricultura, 1979. p.207-232.

PENSON, J.B. et al. Measurement of capacity depreciation based on engeneering data. American Journal of Agricultural Economics, v.59, n.2, p.321-29, 1977.

PERRY, G.M. et al. The effect of usage and size on tractor depreciation. American Journal of Agricultural Economics, v.73, n.2, p.317-325, 1990.

PINHEIRO, A.M.R.C. An inquiry into the causes of total factor productivity growth in developing countries: the case of brazilian manufactoring, 1970-1980. Berkeley, 1989. Dissertation (PHD) - University of Califórnia at Berkeley. 
RAPPING, L.A. Learning and world war II production functions. Review of Economics and Statistics, v.47, n.1, p.81-86, 1965.

REID, D.W.; BRADFORD, G.I. On optimal replacement of farm tractors. American Journal of Agricuitural Economics, v.65, n.2, p.326-331.

REZENDE, G.C. Agricultura e ajuste externo no Brasil: novas considerações. Pesquisa e Planejamento Econômico, v.19, n.4, p.553-578, dez.1989b.

REZENDE, G.C. Ajuste externo e agricultura no Brasil, 1981-86. Revista Brasileira de Economia, v.42, n.2, p.101-137, abr/jun. 1988.

REZENDE, G.C. Crescimento econômico e oferta de alimentos no Brasil. Revista de Economia Política, v.6, n.1, p.64-81, jan/abr. 1986.

REZENDE, G.C. Política econômica e a agricultura na década de 80 . In: CONGRESSO BRASILEIRO DE ECONOMIA E SOCIOLOGIA RURAL, 28., Piracicaba, 1989. Anais. Brasília: SOBER, 1989. p.284-309.

REZENDE, G.C.; BUAINAIN, A.M. Structural adjustment and agriculture in Brazil: the experience of the 1980's. Revista Brasileira de Economia, v.48, n.4, p.491503, out/dez 1994.

ROCHA, S. Tratores agrícolas: um estudo do determinantes da demanda interna. Revista Brasileira de Estatística, v.47, n.188, p.529-570, out/dez 1986.

ROMER, D. Advanced macroeconomics. New York: McGraw Hill, 1996. 540p.

ROMER, P. Endogenous technicological change. Jounal of Political Economy, v.98, n.5, p.71-102, part.II, october 1990.

ROMER, P. Increasing returns and long run growth. Journal of Political Economy, v.94, n.5, p.1002-1037, 1986.

ROSEGRANT, M.W.; EVENSON, R.E. Agricultural productivity and sources of growth in South Asia. American Journal of Agricultural Economics, v.74, n.3, p.757-761, 1992. 
SANDERS, J.H.; RUTTAN, V.W. Biased choice of technology in brazilian agriculture. In: BINSWANGER, H.P. et al. Induced innovation: technology, institution and development. New York: John Hopkins University Press, 1978. p.276-296.

SCHULTZ, T.W. Agriculture in an unstable economy. New York: McGraw Hill, 1945. 299p.

SCHUMPETER, J.A. A teoria do desenvolvimento econômico: uma investigação sobre lucros, capital, crédito, juros e ciclos econômicos. São Paulo: Abril Cultural, 1982. 169p.

SELVANATHAN, E.A.; RAO, D.S.P. Index numbers: a stochastic approach. London: McMillan, 1994. 241p.

SILBERBERG, E. The structure of economics: a mathematical analysis. 2.ed. New York: MacGraw-Hill, 1990. 686p.

SILVA, G.L.S.P. Transforming brazilian agriculture. In: CONGRESSO BRASILEIRO DE ECONOMIA E SOCIOLOGIA RURAL, 29., Campinas, 1991. Anais. Brasília: SOBER, 1991. p.254-278.

SILVA, G.L.S.P.; CARMO, H.C.E. Como medir a produtividade agrícola: conceitos, métodos e aplicações no caso de São Paulo. São Paulo: Secretaria da Agricultura e Abastecimento e Instituto de Economia Agrícola, 1986. 29p. (Relatório de Pesquisa - IEA, n.3/86).

SILVA, J.G.; KAGEYAMA, A.A. Emprego e relações de trabalho na agricultura: uma análise dos dados censitários de 1960, 1970 e 1975. Pequisa e Planejamento Econômico, v.13, n.1, p.235-266, 1983.

SILVA, L.A.C. A função de produção da agropecuária brasileira: diferenças regionais e evolução no período 1975-1885. Piracicaba, 1996. 157p. Tese (Doutorado) Escola Superior de Agricultura Luiz de Queiroz, Universidade de São Paulo.

SOLOW, R. A contribution to the theory of economic growth. Quaterly Journal of Economics, v.70, n.1, p.65-91, 1956. 
SOLOW, R. Capital theory and the rate of return. North. Amsterdam: North Publishing Company, 1963. 95p.

SOLOW, R. Growth theory: an exposition. New York: Oxford University Press, 1970. 109p.

SOLOW, R. Learning from learning by doing: lessons for economic growth. Stanford: Stanford University Press, 1997.

SOLOW, R. Technical change and the agregate production function. Review of Economics and Statistics, v.39, n.3, p.312-320, 1957.

STERN, N. Growth theories, old and new, and the role of agriculture in economic development. London: London School of Economics, 1994. (Paper 17/P42).

STERN, N. The determinants of growth. Economic Journal, n.101, p.122-133, 1991.

TEIXEIRA, L.F.G.; BALASTREIRE, L.A. Equação para Determinação do Custo

Acumulado de Reparos e Manutenções para Tratores Agrícolas de Pneus.

Piracicaba, Escola Superior de Agricultura Luiz de Queiróz, Departamento de Engenharia Rural, (mimeo), 1996. 21 p.

TWEETEN, L. Farm policy analisis. Boulder: Westview Press, 1989. 397p.

VEIGA, J.E. O desenvolvimento agrícola: uma visão histórica. São Paulo: EDUSPHUCITEC, 1991. 219p.

WYKOFF, F. Capital depreciation in the postwar period: automobiles. Review of Economis and Statistics, v.52, n.2, p.168-172, 1970. 
APÊNDICE A 
Tabela A1) Número Total de Tratores de Roda por Estado da Federação em 1995

\begin{tabular}{lc}
\hline Estados & Número de Tratores \\
\hline Acre & 433 \\
Alagoas & 3.630 \\
Amapá & 150 \\
Amazonas & 515 \\
Bahia & 25.443 \\
Ceará & 4.528 \\
Distrito Federal & 2.232 \\
Espírito Santo & 10.995 \\
Goiás & 43.313 \\
Maranhão & 3.965 \\
Mato Grosso & 32.752 \\
Mato Grosso do Sul & 36.387 \\
Minas Gerais & 89.667 \\
Pará & 6.067 \\
Paraíba & 3.225 \\
Paraná & 121.827 \\
Pernambuco & 5.649 \\
Piauí & 2.402 \\
Rio de Janeiro & 8.796 \\
Rio Grande do Norte & 3.650 \\
Rio Grande do Sul & 150.074 \\
Rondônia & 3.061 \\
Roraima & 260 \\
Santa Catarina & 63.148 \\
São Paulo & 170.573 \\
Sergipe & 2.984 \\
Tocantins & 7.950 \\
TOTAL & $\mathbf{8 0 3 . 6 7 6}$ \\
\hline
\end{tabular}

Fonte: Censo Agropecuário 
Tabela A2) Número de Tratores de Rodas Vendidos Ao Mercado Interno por Faixa de Potência entre 1970-1997

\begin{tabular}{cccccc}
\hline Ano & Até 49 cv & De 50 a 99 cv & De 100 a 199 cv & Mais do que 200 cv & TOTAL \\
\hline 1970 & 3.429 & 9.046 & 2.265 & 0 & 14.740 \\
1971 & 4.104 & 14.186 & 3.927 & 0 & 22.217 \\
1972 & 6.140 & 18.575 & 4.989 & 0 & 29.704 \\
1973 & 8.324 & 23.344 & 7.786 & 0 & 39.454 \\
1974 & 10.299 & 26.368 & 9.328 & 0 & 45.995 \\
1975 & 9.686 & 37.619 & 10.626 & 0 & 57.931 \\
1976 & 9.348 & 42.253 & 12.175 & 0 & 63.776 \\
1977 & 8.011 & 36.023 & 4.379 & 155 & 48.568 \\
1978 & 6.918 & 29.254 & 5.447 & 0 & 41.619 \\
1979 & 4.951 & 35.699 & 6.706 & 2.167 & 49.523 \\
1980 & 5.411 & 37.895 & 7.372 & 316 & 50.994 \\
1981 & 2.933 & 18.427 & 6.555 & 189 & 28.104 \\
1982 & 2.529 & 18.017 & 4.004 & 112 & 24.662 \\
1983 & 1.809 & 16.160 & 4.407 & 170 & 22.546 \\
1984 & 3.110 & 32.367 & 6.301 & 174 & 41.952 \\
1985 & 3.892 & 31.045 & 6.188 & 118 & 41.243 \\
1986 & 4.382 & 36.306 & 5.482 & 218 & 46.388 \\
1987 & 3.644 & 29.489 & 6.536 & 133 & 39.802 \\
1988 & 2.475 & 21.084 & 6.967 & 78 & 30.604 \\
1989 & 2.513 & 18.002 & 6.365 & 75 & 26.955 \\
1990 & 1.965 & 15.528 & 4.490 & 29 & 22.012 \\
1991 & 1.333 & 9.254 & 3.283 & 26 & 13.896 \\
1992 & 5.273 & 3.171 & 1.538 & 0 & 9.982 \\
1993 & 828 & 14.219 & 6.813 & 25 & 21.885 \\
1994 & 1.275 & 27.143 & 10.046 & 27 & 38.491 \\
1995 & 1.176 & 13.418 & 2.988 & 1 & 17.584 \\
1996 & 655 & 7.008 & 2.627 & 2 & 10.291 \\
1997 & 855 & 10.210 & 4.664 & & 15.731 \\
\hline
\end{tabular}

Fonte: ANFAVEA 
Tabela A3) Número de Tratores de Rodas Importados entre 1970-1997

\begin{tabular}{cc}
\hline Ano & Número \\
\hline 1970 & 60 \\
1971 & 184 \\
1972 & 228 \\
1973 & 258 \\
1974 & 347 \\
1975 & 801 \\
1976 & 191 \\
1977 & 39 \\
1978 & 195 \\
1979 & 194 \\
1980 & 55 \\
1981 & 53 \\
1982 & 21 \\
1983 & 15 \\
1984 & 11 \\
1985 & 6 \\
1986 & 2 \\
1987 & 7 \\
1988 & 11 \\
1989 & 13 \\
1990 & 29 \\
1991 & 154 \\
1992 & 208 \\
1993 & 333 \\
1994 & 616 \\
1995 & 761 \\
1996 & 514 \\
1997 & 1.625 \\
\hline &
\end{tabular}

Fonte: Barros (1980) e CACEX 
Tabela A4) Preço do Trator Massey Fergusson 275

\begin{tabular}{ccccccccc}
\hline DATA & $23 / 04 / 97$ & $28 / 05 / 97$ & $25 / 06 / 97$ & $30 / 07 / 97$ & $24 / 09 / 97$ & $05 / 11 / 97$ & $28 / 01 / 98$ & $29 / 04 / 98$ \\
\hline 0 & 27.500 & 27.500 & 27.800 & 27.500 & 26.400 & 25.700 & 25.700 & 26.500 \\
1 & 24.150 & 23.000 & 24.150 & 20.500 & 17.000 & 19.000 & 19.900 & 20.000 \\
2 & 19.950 & 19.000 & 19.950 & 18.000 & 14.150 & 15.700 & 19.000 & 19.000 \\
3 & 18.900 & 18.000 & 18.900 & 17.000 & 13.500 & 15.000 & 15.700 & 18.100 \\
4 & 16.800 & 16.000 & 16.800 & 15.100 & 12.500 & 14.000 & 15.000 & 17.200 \\
5 & 13.860 & 13.200 & 13.860 & 12.500 & 11.500 & 12.800 & 14.000 & 16.300 \\
6 & 12.600 & 12.000 & 12.600 & 11.800 & 11.000 & 12.300 & 12.800 & 15.500 \\
7 & 12.075 & 11.500 & 12.075 & 10.500 & 10.500 & 11.700 & 12.300 & 14.700 \\
8 & 11.550 & 11.000 & 11.550 & 10.000 & 10.000 & 11.200 & 11.700 & 14.000 \\
9 & 10.500 & 10.000 & 10.500 & 10.000 & 9.600 & 10.700 & 11.200 & 13.300 \\
10 & 9.450 & 9.000 & 9.450 & 9.300 & 9.300 & 10.400 & 10.700 & 12.600 \\
11 & 9.240 & 8.800 & 9.240 & 9.240 & 9.000 & 10.100 & 10.400 & 12.000 \\
12 & 8.925 & 8.500 & 8.925 & 8.925 & 8.500 & 9.500 & 10.400 & 11.400 \\
13 & 8.400 & 8.000 & 8.400 & 8.400 & 8.200 & 9.000 & 9.500 & 10.800 \\
14 & 7.980 & 7.600 & 7.980 & 7.980 & 8.000 & 8.000 & 9.000 & 10.300 \\
15 & 7.770 & 7.400 & 7.770 & 7.770 & 7.900 & 7.900 & 8.000 & 9.800 \\
16 & 7.560 & 7.200 & 7.560 & 7.560 & 7.500 & 7.600 & 7.900 & 9.300 \\
17 & 7.140 & 6.800 & 7.140 & 7.140 & 7.100 & 7.100 & 7.500 & 8.800 \\
18 & 6.720 & 6.400 & 6.720 & 6.720 & 6.700 & 6.700 & 7.100 & 8.400 \\
19 & 6.405 & 6.100 & 6.405 & 6.405 & 6.400 & 6.400 & 6.700 & 8.000 \\
20 & 5.985 & 5.700 & 5.985 & 5.985 & 6.000 & 6.000 & 6.400 & 7.600 \\
21 & 5.670 & 5.400 & 5.670 & 5.670 & 5.600 & 5.500 & 6.000 & 7.200 \\
\hline
\end{tabular}

Fonte: Jornal O Estado de São Paulo 
Tabela A5) Preço do Trator Massey Fergusson 290

\begin{tabular}{cccccccc}
\hline DATA & $23 / 04 / 97$ & $28 / 05 / 97$ & $30 / 07 / 97$ & $31 / 12 / 97$ & $28 / 01 / 98$ & $29 / 04 / 98$ & $30 / 09 / 98$ \\
\hline 0 & 32.000 & 32.000 & 32.100 & 30.800 & 30.800 & 31.800 & 31.700 \\
1 & 27.200 & 28.560 & 24.500 & 23.000 & 25.000 & 22.000 & 22.000 \\
2 & 24.000 & 25.200 & 24.200 & 21.000 & 23.000 & 20.800 & 20.800 \\
3 & 22.000 & 23.100 & 23.100 & 19.000 & 21.000 & 19.700 & 19.700 \\
4 & 21.000 & 22.050 & 22.050 & 17.000 & 19.000 & 18.600 & 18.600 \\
5 & 19.300 & 20.265 & 20.265 & 15.500 & 17.000 & 17.600 & 17.600 \\
6 & 17.600 & 18.480 & 18.480 & 14.500 & 15.500 & 16.600 & 16.600 \\
7 & 14.300 & 15.015 & 15.015 & 14.000 & 14.500 & 15.700 & 15.700 \\
8 & 13.500 & 14.175 & 14.175 & 13.600 & 14.000 & 14.800 & 14.800 \\
9 & 13.000 & 13.650 & 13.650 & 13.200 & 13.600 & 14.000 & 14.000 \\
10 & 12.500 & 13.125 & 13.125 & 12.600 & 13.200 & 13.200 & 13.200 \\
11 & 12.000 & 12.600 & 12.600 & 12.000 & 12.600 & 12.500 & 13.000 \\
12 & 11.200 & 11.760 & 11.760 & 11.500 & 12.000 & 11.800 & 12.500 \\
13 & 11.000 & 11.550 & 11.550 & 11.000 & 11.500 & 11.200 & 11.500 \\
14 & 10.500 & 11.025 & 11.025 & 10.500 & 11.000 & 10.600 & 10.600 \\
15 & 10.000 & 10.500 & 10.500 & 10.000 & 10.500 & 10.000 & 10.000 \\
16 & 9.500 & 9.975 & 9.975 & 9.500 & 10.000 & 9.500 & 9.500 \\
17 & 9.000 & 9.450 & 9.450 & 9.000 & 9.500 & 9.000 & 9.000 \\
18 & 8.500 & 8.925 & 8.925 & 8.500 & 9.000 & 8.500 & 8.500 \\
19 & 8.000 & 8.400 & 8.400 & 8.000 & 8.500 & 8.000 & 8.300 \\
20 & 7.500 & 7.875 & 7.875 & 7.700 & 8.000 & 7.600 & 8.000 \\
21 & 7.000 & 7.350 & 7.350 & 7.300 & 7.700 & 7.200 & 7.200 \\
\hline
\end{tabular}

Fonte: Jornal O Estado de São Paulo 
Tabela A6) Análise da Variância dos Preços do Trator 275

\begin{tabular}{ccccc} 
RESUMO & \multicolumn{5}{c}{ Contagem } & Soma & Média & Variância \\
\hline Grupo & 21 & 1,499375936 & 0,071398854 & 0,001939048 \\
Linha 1 & 21 & 1,541194118 & 0,073390196 & 0,002233166 \\
Linha 2 & 21 & 1,508852719 & 0,071850129 & 0,001991106 \\
Linha 3 & 21 & 1,481959207 & 0,070569486 & 0,003357588 \\
Linha 4 & 21 & 1,425765029 & 0,067893573 & 0,005297183 \\
Linha 5 & 21 & 1,449816233 & 0,069038868 & 0,003088019 \\
Linha 6 & 21 & 1,375178029 & 0,065484668 & 0,002631733 \\
Linha 7 & 21 & 1,241223696 & 0,05910589 & 0,001824977 \\
Linha 8 & & & & \\
\hline
\end{tabular}

ANOVA

\begin{tabular}{ccccccc}
\hline Fonte da variação & $S Q$ & $g l$ & $M Q$ & $F$ & valor- $P$ & $F$ crítico \\
\hline Entre grupos & 0,003060881 & 7 & 0,000437269 & 0,156427056 & 0,99289 & 2,06724 \\
Dentro dos grupos & 0,447256397 & 160 & 0,002795352 & & & \\
& & & & & & \\
Total & 0,450317278 & 167 & & & & \\
\hline
\end{tabular}


Tabela A7) Análise da Variância dos Preços do Trator 290

RESUMO

\begin{tabular}{lcccc}
\hline Grupo & Contagem & Soma & Média & Variância \\
\hline Linha 1 & 21 & 1,448187585 & 0,068961314 & 0,00158979 \\
Linha 2 & 21 & 1,405687585 & 0,066937504 & 0,001331387 \\
Linha 3 & 21 & 1,391666761 & 0,066269846 & 0,002721265 \\
Linha 4 & 21 & 1,363672733 & 0,064936797 & 0,002316354 \\
Linha 5 & 21 & 1,326789616 & 0,063180458 & 0,001304061 \\
Linha 6 & 21 & 1,394459182 & 0,066402818 & 0,003074612 \\
Linha 7 & 21 & 1,388920388 & 0,066139066 & 0,00334229 \\
\hline
\end{tabular}

ANOVA

\begin{tabular}{ccccccc}
\hline Fonte da variação & $S Q$ & $g l$ & $M Q$ & $F$ & valor- $P$ & $F$ crítico \\
\hline Entre grupos & 0,000396586 & 6 & $6,60976 \mathrm{E}-05$ & 0,029508319 & 0,99989 & 2,16393 \\
Dentro dos grupos & 0,3135952 & 140 & 0,002239966 & & & \\
& & & & & & \\
Total & 0,313991785 & 146 & & & & \\
\hline
\end{tabular}


Tabela A8) Análise da Variância dos Preços dos Tratores 275 e 290

\begin{tabular}{|c|c|c|c|c|}
\hline Grupo & Contagem & Soma & Média & Variância \\
\hline Linha 1 & 21 & 1,448187585 & 0,068961314 & 0,00158979 \\
\hline Linha 2 & 21 & 1,405687585 & 0,066937504 & 0,001331387 \\
\hline Linha 3 & 21 & 1,391666761 & 0,066269846 & 0,002721265 \\
\hline Linha 4 & 21 & 1,363672733 & 0,064936797 & 0,002316354 \\
\hline Linha 5 & 21 & 1,326789616 & 0,063180458 & 0,001304061 \\
\hline Linha 6 & 21 & 1,394459182 & 0,066402818 & 0,003074612 \\
\hline Linha 7 & 21 & 1,388920388 & 0,066139066 & 0,00334229 \\
\hline Linha 8 & 21 & 1,499375936 & 0,071398854 & 0,001939048 \\
\hline Linha 9 & 21 & 1,541194118 & 0,073390196 & 0,002233166 \\
\hline Linha 10 & 21 & 1,508852719 & 0,071850129 & 0,001991106 \\
\hline Linha 11 & 21 & 1,481959207 & 0,070569486 & 0,003357588 \\
\hline Linha 12 & 21 & 1,425765029 & 0,067893573 & 0,005297183 \\
\hline Linha 13 & 21 & 1,449816233 & 0,069038868 & 0,003088019 \\
\hline Linha 14 & 21 & 1,375178029 & 0,065484668 & 0,002631733 \\
\hline Linha 15 & 21 & 1,241223696 & 0,05910589 & 0,001824977 \\
\hline
\end{tabular}

ANOVA

\begin{tabular}{ccccccc}
\hline Fonte da variação & $S Q$ & $g l$ & $M Q$ & $F$ & valor- $P$ & $F$ crítico \\
\hline Entre grupos & 0,003937018 & 14 & 0,000281216 & 0,110881902 & 0,9999809 & 1,7248567 \\
Dentro dos grupos & 0,760851596 & 300 & 0,002536172 & & & \\
& & & & & & \\
Total & 0,764788614 & 314 & & & & \\
\hline
\end{tabular}


Tabela A9) Preço Nominal dos Tratores Novos

\begin{tabular}{ccccc}
\hline Ano & Até 49 cv & De 50 a 99 cv & De 100 a 199 cv & Acima de 200 cv \\
\hline 1973 & 27.559 & 45.472 & 68.898 & 93.701 \\
1974 & 31.399 & 51.808 & 78.498 & 106.757 \\
1975 & 44.259 & 73.027 & 110.648 & 150.481 \\
1976 & 69.862 & 115.272 & 174.655 & 237.531 \\
1977 & 113.708 & 187.618 & 284.270 & 386.607 \\
1978 & 159.992 & 263.987 & 399.980 & 543.973 \\
1979 & 240.502 & 396.828 & 601.255 & 817.707 \\
1980 & 461.093 & 760.803 & 1.152 .733 & 1.567 .716 \\
1981 & 1.099 .123 & 1.813 .553 & 2.747 .808 & 3.737 .018 \\
1982 & 2.786 .000 & 4.596 .900 & 6.965 .000 & 9.472 .400 \\
1983 & 6.338 .000 & 10.457 .700 & 15.845 .000 & 21.549 .200 \\
1984 & 23.440 .000 & 38.676 .000 & 58.600 .000 & 79.696 .000 \\
1985 & 64.442 .000 & 106.329 .300 & 161.105 .000 & 219.102 .800 \\
1986 & 100.373 & 165.615 & 250.933 & 341.268 \\
1987 & 720.598 & 1.188 .987 & 1.801 .495 & 2.450 .033 \\
1988 & 10.207 .534 & 16.842 .431 & 25.518 .835 & 34.705 .616 \\
1989 & 184.076 & 303.725 & 460.190 & 625.858 \\
1990 & 1.963 .830 & 3.240 .320 & 4.909 .575 & 6.677 .022 \\
1991 & 17.765 .980 & 29.313 .867 & 44.414 .950 & 60.404 .332 \\
1992 & 261.429 .668 & 431.358 .952 & 653.574 .170 & 888.860 .871 \\
1993 & 6.802 .530 & 11.224 .175 & 17.006 .325 & 23.128 .602 \\
1994 & 20.748 & 34.234 & 51.870 & 70.543 \\
1995 & 20.748 & 34.234 & 51.870 & 70.543 \\
\hline
\end{tabular}

Fonte: IEA 
APÊNDICE B 
Tabela B1) Valor da Produção Total e Valor da Produção de Lavouras entre 1973 e 1995 ( $\mathrm{R} \$$ dezembro 1995)

\begin{tabular}{ccc}
\hline Ano & Valor Agricultura & Valor Pecuária \\
\hline 1973 & 17.313 .705 .490 & 1.870 .417 .331 \\
1974 & 20.338 .901 .231 & 2.142 .283 .995 \\
1975 & 19.828 .737 .461 & 3.303 .796 .031 \\
1976 & 18.780 .660 .048 & 3.507 .394 .358 \\
1977 & 21.400 .925 .982 & 3.833 .760 .252 \\
1978 & 21.977 .497 .392 & 4.091 .890 .723 \\
1979 & 21.818 .427 .659 & 4.410 .705 .279 \\
1980 & 22.735 .774 .264 & 4.929 .739 .883 \\
1981 & 25.675 .886 .663 & 5.065 .097 .164 \\
1982 & 24.654 .315 .741 & 5.114 .467 .026 \\
1983 & 23.761 .064 .319 & 5.115 .554 .857 \\
1984 & 27.183 .883 .170 & 5.253 .885 .297 \\
1985 & 30.365 .772 .331 & 5.360 .364 .594 \\
1986 & 26.292 .534 .837 & 5.639 .200 .988 \\
1987 & 31.400 .653 .733 & 6.095 .782 .093 \\
1988 & 26.630 .001 .327 & 6.124 .122 .051 \\
1989 & 27.508 .721 .585 & 6.244 .074 .321 \\
1990 & 25.353 .038 .621 & 6.619 .777 .490 \\
1991 & 25.797 .594 .129 & 7.075 .059 .119 \\
1992 & 26.770 .120 .339 & 7.420 .485 .123 \\
1993 & 26.450 .957 .457 & 7.451 .306 .134 \\
1994 & 28.591 .753 .459 & 7.919 .931 .774 \\
1995 & 28.355 .846 .000 & 8.556 .481 .577 \\
\hline
\end{tabular}

Fonte: IBGE - PAM 
Tabela B2) Pessoal Ocupado, Fertilizantes Consumidos e Área Total Cultivada entre 1973 e 1995

\begin{tabular}{cccc}
\hline Ano & $\begin{array}{c}\text { Pessoal Ocupado } \\
\mathbf{N}^{\mathbf{0}} \text { de pessoas }\end{array}$ & $\begin{array}{c}\text { Fertilizantes } \\
\text { Ton de Nutrientes }\end{array}$ & $\begin{array}{c}\text { Área } \\
\text { hectares }\end{array}$ \\
\hline 1973 & 11.998 .339 & 1.388 .354 & 38.921 .902 \\
1974 & 11.819 .751 & 1.560 .680 & 41.686 .053 \\
1975 & 11.641 .163 & 1.560 .878 & 43.370 .817 \\
1976 & 11.462 .575 & 1.930 .120 & 44.602 .417 \\
1977 & 12.083 .387 & 2.758 .446 & 47.176 .881 \\
1978 & 11.563 .849 & 2.812 .928 & 46.851 .522 \\
1979 & 11.489 .322 & 3.118 .570 & 48.091 .231 \\
1980 & 10.128 .814 & 3.626 .200 & 49.517 .380 \\
1981 & 10.639 .870 & 2.675 .322 & 48.726 .510 \\
1982 & 11.311 .566 & 2.578 .416 & 51.163 .239 \\
1983 & 10.492 .118 & 2.216 .530 & 45.253 .352 \\
1984 & 11.979 .553 & 3.299 .712 & 49.792 .110 \\
1985 & 12.152 .314 & 3.315 .326 & 51.781 .417 \\
1986 & 11.464 .504 & 3.490 .018 & 53.591 .508 \\
1987 & 11.292 .924 & 3.686 .927 & 53.473 .455 \\
1988 & 11.386 .646 & 3.728 .588 & 55.324 .169 \\
1989 & 11.227 .906 & 3.383 .157 & 55.102 .110 \\
1990 & 11.344 .415 & 3.148 .290 & 50.344 .165 \\
1991 & 10.044 .623 & 3.204 .888 & 50.473 .911 \\
1992 & 11.960 .671 & 3.584 .367 & 50.520 .458 \\
1993 & 11.733 .462 & 4.150 .279 & 46.432 .598 \\
1994 & 11.315 .373 & 4.732 .285 & 51.154 .129 \\
1995 & 11.625 .138 & 4.308 .799 & 50.561 .866 \\
\hline
\end{tabular}

Fonte: IBGE e ANDA 
Tabela B3) Participação dos Fatores de Produção no Produto Total sem Considerar Rebanho Pecuário

\begin{tabular}{cccccccccccccc}
\hline \multicolumn{1}{c}{ VALOR DO ESTOQUE } & \multicolumn{3}{c}{ VALOR DA PMg do CAPITAL } & \multicolumn{3}{c}{ VALOR DOS SERVICOS } \\
\hline ano & máquina & terra & fert. & mo & máquina & terra & fert. & mo & máquina & terra & fert. & mo \\
\hline 1975 & 0,12 & 0,19 & 0,09 & 0,60 & 0,26 & 0,16 & 0,07 & 0,51 & 0,07 & 0,20 & 0,09 & 0,64 \\
1976 & 0,16 & 0,17 & 0,08 & 0,60 & 0,26 & 0,15 & 0,07 & 0,52 & 0,09 & 0,18 & 0,08 & 0,64 \\
1977 & 0,17 & 0,17 & 0,09 & 0,56 & 0,28 & 0,15 & 0,08 & 0,49 & 0,10 & 0,19 & 0,10 & 0,61 \\
1978 & 0,18 & 0,16 & 0,09 & 0,57 & 0,25 & 0,14 & 0,08 & 0,52 & 0,11 & 0,17 & 0,10 & 0,62 \\
1979 & 0,17 & 0,15 & 0,11 & 0,56 & 0,24 & 0,14 & 0,10 & 0,52 & 0,11 & 0,16 & 0,12 & 0,61 \\
1980 & 0,18 & 0,18 & 0,15 & 0,50 & 0,25 & 0,16 & 0,14 & 0,45 & 0,11 & 0,19 & 0,16 & 0,54 \\
1981 & 0,19 & 0,19 & 0,11 & 0,51 & 0,24 & 0,18 & 0,10 & 0,48 & 0,12 & 0,21 & 0,12 & 0,55 \\
1982 & 0,23 & 0,17 & 0,09 & 0,51 & 0,21 & 0,18 & 0,09 & 0,52 & 0,15 & 0,19 & 0,10 & 0,55 \\
1983 & 0,23 & 0,18 & 0,11 & 0,48 & 0,25 & 0,18 & 0,10 & 0,47 & 0,16 & 0,20 & 0,12 & 0,53 \\
1984 & 0,23 & 0,17 & 0,14 & 0,46 & 0,23 & 0,17 & 0,14 & 0,46 & 0,16 & 0,19 & 0,15 & 0,50 \\
1985 & 0,19 & 0,19 & 0,12 & 0,50 & 0,24 & 0,18 & 0,11 & 0,47 & 0,13 & 0,20 & 0,13 & 0,54 \\
1986 & 0,17 & 0,23 & 0,10 & 0,50 & 0,27 & 0,20 & 0,09 & 0,44 & 0,12 & 0,24 & 0,11 & 0,53 \\
1987 & 0,30 & 0,18 & 0,12 & 0,39 & 0,23 & 0,20 & 0,13 & 0,43 & 0,23 & 0,20 & 0,13 & 0,44 \\
1988 & 0,34 & 0,20 & 0,11 & 0,34 & 0,17 & 0,25 & 0,14 & 0,43 & 0,27 & 0,22 & 0,13 & 0,39 \\
1989 & 0,36 & 0,16 & 0,10 & 0,39 & 0,16 & 0,21 & 0,13 & 0,50 & 0,28 & 0,18 & 0,11 & 0,43 \\
1990 & 0,28 & 0,22 & 0,13 & 0,37 & 0,18 & 0,25 & 0,15 & 0,42 & 0,22 & 0,24 & 0,14 & 0,40 \\
1991 & 0,40 & 0,20 & 0,10 & 0,30 & 0,18 & 0,28 & 0,13 & 0,41 & 0,34 & 0,23 & 0,11 & 0,33 \\
1992 & 0,43 & 0,17 & 0,10 & 0,30 & 0,17 & 0,24 & 0,15 & 0,43 & 0,37 & 0,19 & 0,11 & 0,33 \\
1993 & 0,39 & 0,18 & 0,10 & 0,33 & 0,13 & 0,25 & 0,15 & 0,47 & 0,34 & 0,19 & 0,11 & 0,36 \\
1994 & 0,32 & 0,21 & 0,12 & 0,35 & 0,30 & 0,22 & 0,13 & 0,36 & 0,26 & 0,23 & 0,13 & 0,38 \\
1995 & 0,27 & 0,17 & 0,11 & 0,45 & 0,27 & 0,17 & 0,12 & 0,45 & 0,23 & 0,18 & 0,12 & 0,47 \\
MÉnIA & $\mathbf{0 , 2 5}$ & $\mathbf{0 , 1 8}$ & $\mathbf{0 , 1 1}$ & $\mathbf{0 , 4 6}$ & $\mathbf{0 , 2 3}$ & $\mathbf{0 , 1 9}$ & $\mathbf{0 , 1 1}$ & $\mathbf{0 , 4 6}$ & $\mathbf{0 , 1 9}$ & $\mathbf{0 , 2 0}$ & $\mathbf{0 , 1 2}$ & $\mathbf{0 , 4 9}$ \\
\hline
\end{tabular}


Tabela B4) Participação dos Fatores de Produção no Produto Total Considerando Rebanho Pecuário

\begin{tabular}{|c|c|c|c|c|c|c|c|c|c|c|c|c|c|c|c|}
\hline \multirow[b]{2}{*}{ ano } & \multicolumn{5}{|c|}{ VALOR DO ESTOQUE } & \multicolumn{5}{|c|}{ VALOR DA PMg do CAPITAL } & \multicolumn{5}{|c|}{ VALOR DOS SERVIÇOS } \\
\hline & máquina & terra & fertilizantes & trabalho & rebanho & máquina & terra & fertilizantes & trabalho & rebanho & máguina & terra & fertilizantes & trabalho & rebanho \\
\hline 1975 & 0,08 & 0,13 & 0,06 & 0,42 & 0,30 & 0,19 & 0,11 & 0,05 & 0,37 & 0,27 & 0,05 & 0,13 & 0,06 & 0,44 & 0,32 \\
\hline 1976 & 0,11 & 0,12 & 0,06 & 0,44 & 0,27 & 0,20 & 0,11 & 0,05 & 0,39 & 0,24 & 0,07 & 0,13 & 0,06 & 0,46 & 0,28 \\
\hline 1977 & 0,13 & 0,13 & 0,07 & 0,41 & 0,27 & 0,21 & 0,11 & 0,06 & 0,37 & 0,25 & 0,07 & 0,13 & 0,07 & 0,43 & 0,29 \\
\hline 1978 & 0,13 & 0,11 & 0,06 & 0,39 & 0,31 & 0,18 & 0,10 & 0,06 & 0,37 & 0,29 & 0,08 & 0,12 & 0,07 & 0,42 & 0,32 \\
\hline 1979 & 0,11 & 0,10 & 0,07 & 0,37 & 0,34 & 0,16 & 0,09 & 0,07 & 0,35 & 0,32 & 0,07 & 0,10 & 0,08 & 0,39 & 0,36 \\
\hline 1980 & 0,12 & 0,12 & 0,10 & 0,33 & 0,34 & 0,17 & 0,11 & 0,09 & 0,31 & 0,32 & 0,07 & 0,12 & 0,10 & 0,35 & 0,36 \\
\hline 1981 & 0,14 & 0,14 & 0,08 & 0,38 & 0,25 & 0,18 & 0,14 & 0,08 & 0,36 & 0,24 & 0,09 & 0,15 & 0,09 & 0,40 & 0,27 \\
\hline 1982 & 0,18 & 0,14 & 0,07 & 0,40 & 0,22 & 0,17 & 0,14 & 0,07 & 0,40 & 0,22 & 0,12 & 0,15 & 0,08 & 0,43 & 0,23 \\
\hline 1983 & 0,15 & 0,12 & 0,07 & 0,33 & 0,33 & 0,17 & 0,12 & 0,07 & 0,32 & 0,32 & 0,10 & 0,13 & 0,08 & 0,35 & 0,35 \\
\hline 1984 & 0,16 & 0,12 & 0,10 & 0,32 & 0,29 & 0,16 & 0,12 & 0,10 & 0,32 & 0,29 & 0,11 & 0,13 & 0,11 & 0,34 & 0,31 \\
\hline 1985 & 0,14 & 0,14 & 0,09 & 0,37 & 0,27 & 0,18 & 0,13 & 0,08 & 0,35 & 0,25 & 0,09 & 0,15 & 0,09 & 0,39 & 0,28 \\
\hline 1986 & 0,10 & 0,13 & 0,06 & 0,29 & 0,41 & 0,17 & 0,12 & 0,05 & 0,27 & 0,38 & 0,07 & 0,14 & 0,06 & 0,30 & 0,43 \\
\hline 1987 & 0,23 & 0,14 & 0,09 & 0,30 & 0,24 & 0,18 & 0,15 & 0,10 & 0,32 & 0,25 & 0,17 & 0,15 & 0,10 & 0,32 & 0,26 \\
\hline 1988 & 0,25 & 0,15 & 0,08 & 0,25 & 0,26 & 0,12 & 0,17 & 0,10 & 0,30 & 0,31 & 0,19 & 0,16 & 0,09 & 0,28 & 0,28 \\
\hline 1989 & 0,28 & 0,13 & 0,07 & 0,30 & 0,23 & 0,12 & 0,15 & 0,09 & 0,36 & 0,27 & 0,21 & 0,14 & 0,08 & 0,32 & 0,24 \\
\hline 1990 & 0,21 & 0,17 & 0,10 & 0,28 & 0,23 & 0,14 & 0,19 & 0,11 & 0,31 & 0,25 & 0,17 & 0,18 & 0,11 & 0,30 & 0,24 \\
\hline 1991 & 0,31 & 0,16 & 0,07 & 0,23 & 0,23 & 0,13 & 0,20 & 0,09 & 0,29 & 0,29 & 0,25 & 0,17 & 0,08 & 0,25 & 0,25 \\
\hline 1992 & 0,32 & 0,13 & 0,08 & 0,22 & 0,26 & 0,12 & 0,16 & 0,10 & 0,29 & 0,34 & 0,27 & 0,13 & 0,08 & 0,24 & 0,28 \\
\hline 1993 & 0,29 & 0,14 & 0,08 & 0,25 & 0,24 & 0,09 & 0,18 & 0,10 & 0,33 & 0,31 & 0,25 & 0,14 & 0,08 & 0,27 & 0,25 \\
\hline 1994 & 0,23 & 0,15 & 0,09 & 0,25 & 0,28 & 0,21 & 0,15 & 0,09 & 0,26 & 0,29 & 0,19 & 0,16 & 0,09 & 0,27 & 0,30 \\
\hline 1995 & 0,22 & 0,13 & 0,09 & 0,36 & 0,20 & 0.21 & 0,13 & 0,09 & 0,36 & 0,20 & 0,18 & 0,14 & 0,09 & 0,37 & 0,21 \\
\hline MÉDIA & 0,19 & 0,13 & 0,08 & $\mathbf{0 , 3 3}$ & 0,27 & 0,16 & 0,14 & 0,08 & 0,33 & 0,28 & 0,14 & 0,14 & 0,08 & 0,35 & 0,29 \\
\hline
\end{tabular}

